\title{
Pre-operative Nutrition Support in Patients Undergoing Gastrointestinal Surgery. (Review)
}

\author{
Burden S, Todd C, Hill J, Lal S
}

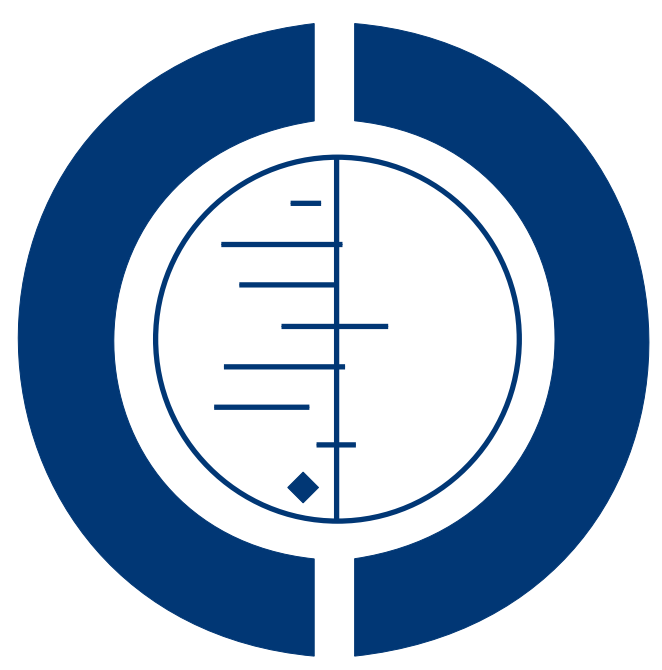

\section{THE COCHRANE COLLABORATION ${ }^{\circledR}$}

This is a reprint of a Cochrane review, prepared and maintained by The Cochrane Collaboration and published in The Cochrane Library 2012, Issue 11

http://www.thecochranelibrary.com

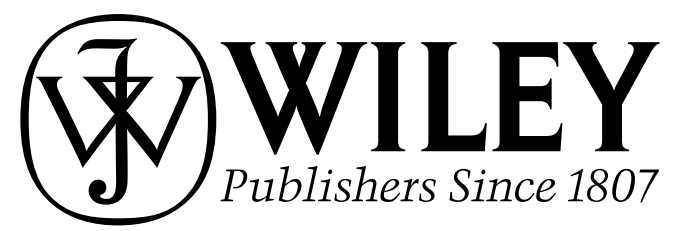

Pre-operative Nutrition Support in Patients Undergoing Gastrointestinal Surgery. (Review)

Copyright $\odot 2012$ The Cochrane Collaboration. Published by John Wiley \& Sons, Ltd. 
TABLE OF CONTENTS

HEADER . . . . . . . . . . . . . . . . . . . . . . . . . . . . . . . . . . . . . . . . . . 1

ABSTRACT . . . . . . . . . . . . . . . . . . . . . . . . . . . . . . . . . . . . . . 1

PLAIN LANGUAGE SUMMARY . . . . . . . . . . . . . . . . . . . . . . . . . . . . . . . . . . . . . . . . . .

SUMMARY OF FINDINGS FOR THE MAIN COMPARISON . . . . . . . . . . . . . . . . . . . . . . . . . . . .

BACKGROUND . . . . . . . . . . . . . . . . . . . . . . . . . . . . . . . . . . . . . . . . . . . 5

OBJECTIVES . . . . . . . . . . . . . . . . . . . . . . . . . . . . . . . . . . . . . . . . . . . . .

METHODS . . . . . . . . . . . . . . . . . . . . . . . . . . . . . . . . . . . . . . .

RESULTS . . . . . . . . . . . . . . . . . . . . . . . . . . . . . . . . . . . . . . .

Figure 1. . . . . . . . . . . . . . . . . . . . . . . . . . . . . . . . . . . . . . 8

Figure 2. . . . . . . . . . . . . . . . . . . . . . . . . . . . . . . . . . . . . . .

Figure 3. . . . . . . . . . . . . . . . . . . . . . . . . . . . . . . . . . . . . . .

Figure 4. . . . . . . . . . . . . . . . . . . . . . . . . . . . . . . . . . . . . . 13

Figure 5. . . . . . . . . . . . . . . . . . . . . . . . . . . . . . . . . . . . . 13

Figure 6. . . . . . . . . . . . . . . . . . . . . . . . . . . . . . . . . . . . . . 14

Figure $7 . \quad$. . . . . . . . . . . . . . . . . . . . . . . . . . . . . . . . . . . . 14

Figure 8. . . . . . . . . . . . . . . . . . . . . . . . . . . . . . . . . . . . . . 14

Figure 9. . . . . . . . . . . . . . . . . . . . . . . . . . . . . . . . . . 15

Figure 10. . . . . . . . . . . . . . . . . . . . . . . . . . . . . . . . . . . . . . 15

Figure 11. . . . . . . . . . . . . . . . . . . . . . . . . . . . . . . . . . . . . . 15

Figure 12. . . . . . . . . . . . . . . . . . . . . . . . . . . . . . . . . . . . . . 16

Figure 13. . . . . . . . . . . . . . . . . . . . . . . . . . . . . . . . . . . . . . 16

Figure $14 . \quad$. . . . . . . . . . . . . . . . . . . . . . . . . . . . . . . . . . . . . 16

Figure 15. . . . . . . . . . . . . . . . . . . . . . . . . . . . . . . . . . . . . . 17

Figure 16. . . . . . . . . . . . . . . . . . . . . . . . . . . . . . . . . . . . . . . . . . .

Figure 17. . . . . . . . . . . . . . . . . . . . . . . . . . . . . . . . . . . . . . . 17

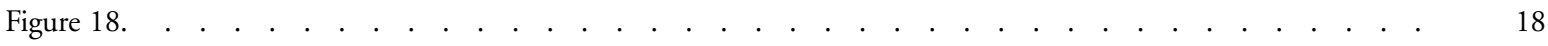

Figure 19.

ADDITIONAL SUMMARY OF FINDINGS . . . . . . . . . . . . . . . . . . . . . . . . . . . . . . . .

DISCUSSION . . . . . . . . . . . . . . . . . . . . . . . . . . . . . . . . . . . . . . . .

AUTHORS' CONCLUSIONS . . . . . . . . . . . . . . . . . . . . . . . . . . . . . . . . . . . .

ACKNOWLEDGEMENTS . . . . . . . . . . . . . . . . . . . . . . . . . . . . . . . . . . . . . .

REFERENCES . . . . . . . . . . . . . . . . . . . . . . . . . . . . . . . . . . . . . . 26

CHARACTERISTICS OF STUDIES . . . . . . . . . . . . . . . . . . . . . . . . . . . . . . . . . . . . . . . . .

DATA AND ANALYSES . . . . . . . . . . . . . . . . . . . . . . . . . . . . . . . . . . . . . . . . . . . . . . . . . . . . . .

Analysis 1.1. Comparison 1 All immune enhancing nutrition trials compared to no nutrition or standard nutrition, Outcome 1 Total complications.

Analysis 1.2. Comparison 1 All immune enhancing nutrition trials compared to no nutrition or standard nutrition,

Outcome 2 Infectious complications.

Analysis 1.3. Comparison 1 All immune enhancing nutrition trials compared to no nutrition or standard nutrition,

Outcome 3 length of stay.

Analysis 2.1. Comparison 2 Preoperative immune enhancing nutrition compared to standard nutrition, Outcome 1 Total complications.

Analysis 2.2. Comparison 2 Preoperative immune enhancing nutrition compared to standard nutrition, Outcome 2 Infectious complications.

Analysis 2.3. Comparison 2 Preoperative immune enhancing nutrition compared to standard nutrition, Outcome 3 Length of stay.

Analysis 3.1. Comparison 3 Preoperative immune enhancing nutrition compared to no nutrition, Outcome 1 Total complications.

Analysis 3.2. Comparison 3 Preoperative immune enhancing nutrition compared to no nutrition, Outcome 2 Infectious complications.

Pre-operative Nutrition Support in Patients Undergoing Gastrointestinal Surgery. (Review)

Copyright @ 2012 The Cochrane Collaboration. Published by John Wiley \& Sons, Ltd. 
Analysis 3.3. Comparison 3 Preoperative immune enhancing nutrition compared to no nutrition, Outcome 3 Length of stay.

Analysis 4.1. Comparison 4 Preoperative standard oral nutrition compared to no nutrition, Outcome 1 Total complications.

Analysis 4.2. Comparison 4 Preoperative standard oral nutrition compared to no nutrition, Outcome 2 Infectious complications. . . . . . . . . . . . . . . . . . . . . . . . . . . . . . . . 54

Analysis 4.3. Comparison 4 Preoperative standard oral nutrition compared to no nutrition, Outcome 3 Length of stay. 55

Analysis 5.1. Comparison 5 Preoperative enteral nutrition compared to no nutrition, Outcome 1 Total complications. 55

Analysis 5.2. Comparison 5 Preoperative enteral nutrition compared to no nutrition, Outcome 2 Infectious complications. 56

Analysis 6.1. Comparison 6 Preoperative parenteral nutrition compared to no nutrition, Outcome 1 Major complications. 57

Analysis 6.2. Comparison 6 Preoperative parenteral nutrition compared to no nutrition, Outcome 2 Infectious

complications.

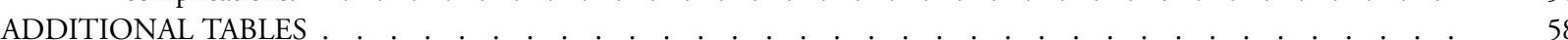

APPENDICES . . . . . . . . . . . . . . . . . . . . . . . . . . . . . . . . . 62

HISTORY . . . . . . . . . . . . . . . . . . . . . . . . . . . . . . . . . . . . . 63

CONTRIBUTIONS OF AUTHORS . . . . . . . . . . . . . . . . . . . . . . . . . . . . . . . . . . . . . . . .

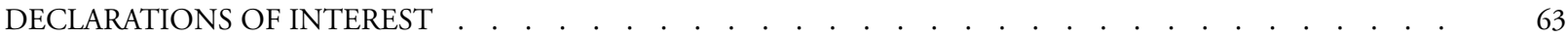

SOURCES OF SUPPORT . . . . . . . . . . . . . . . . . . . . . . . . . . . . . . . . . . . . . . . . . . . . . .

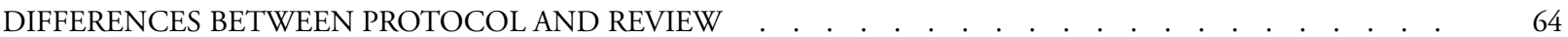

INDEX TERMS . . . . . . . . . . . . . . . . . . . . . . . . . . . . . . . . . . . . 64

Pre-operative Nutrition Support in Patients Undergoing Gastrointestinal Surgery. (Review) 


\title{
[Intervention Review] \\ Pre-operative Nutrition Support in Patients Undergoing Gastrointestinal Surgery.
}

\author{
Sorrel Burden ${ }^{1}$, Chris Todd ${ }^{1}$, James Hill ${ }^{2}$, Simon Lal ${ }^{3}$ \\ ${ }^{1}$ School of Nursing, Midwifery and Social Work, University of Manchester, Manchester, UK. ${ }^{2}$ Department of Surgery, Manchester \\ University Foundation Trust, Manchester, UK. ${ }^{3}$ Intestinal Failure Unit, Salford Royal Foundation Trust, Salford, UK \\ Contact address: Sorrel Burden, School of Nursing, Midwifery and Social Work, University of Manchester, Room 6.32, Jean McFarlane \\ Building, Oxford Road, Manchester, M13 9PL, UK. Sorrel.burden@manchester.ac.uk.
}

Editorial group: Cochrane Colorectal Cancer Group.

Publication status and date: New, published in Issue 11, 2012.

Review content assessed as up-to-date: 13 August 2012.

Citation: Burden S, Todd C, Hill J, Lal S. Pre-operative Nutrition Support in Patients Undergoing Gastrointestinal Surgery.. Cochrane Database of Systematic Reviews 2012, Issue 11. Art. No.: CD008879. DOI: 10.1002/14651858.CD008879.pub2.

Copyright (C) 2012 The Cochrane Collaboration. Published by John Wiley \& Sons, Ltd.

\begin{abstract}
A B S T R A C T
Background

Post-operative management in gastrointestinal (GI) surgery is becoming well established with 'Enhanced Recovery After Surgery' protocols starting 24 hours prior to surgery with carbohydrate loading and early oral or enteral feeding given to patients the first day following surgery. However, whether or not nutritional intervention should be initiated earlier in the preoperative period remains unclear. Poor pre-operative nutritional status has been linked consistently to an increase in post-operative complications and poorer surgical outcome.
\end{abstract}

Objectives

To review the literature on preoperative nutritional support in patients undergoing gastrointestinal surgery (GI).

\section{Search methods}

The searches were initially run in March 2011 and subsequently updated in February 2012. Databases including all EBM Reviews (Cochrane DSR, ACP Journal Club, DARE, CCTR, CMR, HTA and NHSEED) MEDLINE, EMBASE, AMED, British Nursing Index Archive using OvidSP were included and a search was run on each database separately after which duplicates were excluded.

\section{Selection criteria}

The inclusion criteria were randomised controlled trials that evaluated pre-operative nutritional support in GI surgical participants using a nutritional formula delivered by a parenteral, enteral or oral route. The primary outcomes included post-operative complications and length of hospital stay.

\section{Data collection and analysis}

Two observers screened the abstracts for inclusion in the review and performed data extraction. Bias was assessed for each of the included studies using the bias assessment tables in the Cochrane Software Review Manager (version 5.1, Cochrane Collaboration). The trials were analysed using risk ratios with Mantel-Haenszel in fixed effects methods displayed with heterogeneity. Meta-analyses were undertaken on trials evaluating immune enhancing (IE) nutrition, standard oral supplements, enteral and parenteral nutrition (PN) which were administered pre-operatively.

Study characteristics were summarised in tables. Dichotomous and ratio data were entered into meta-analyses for the primary outcomes. These were then summarised in tables with assumed and corresponding risk with relative effect giving $95 \%$ confidence intervals.

Pre-operative Nutrition Support in Patients Undergoing Gastrointestinal Surgery. (Review)

Copyright $\odot 2012$ The Cochrane Collaboration. Published by John Wiley \& Sons, Ltd. 

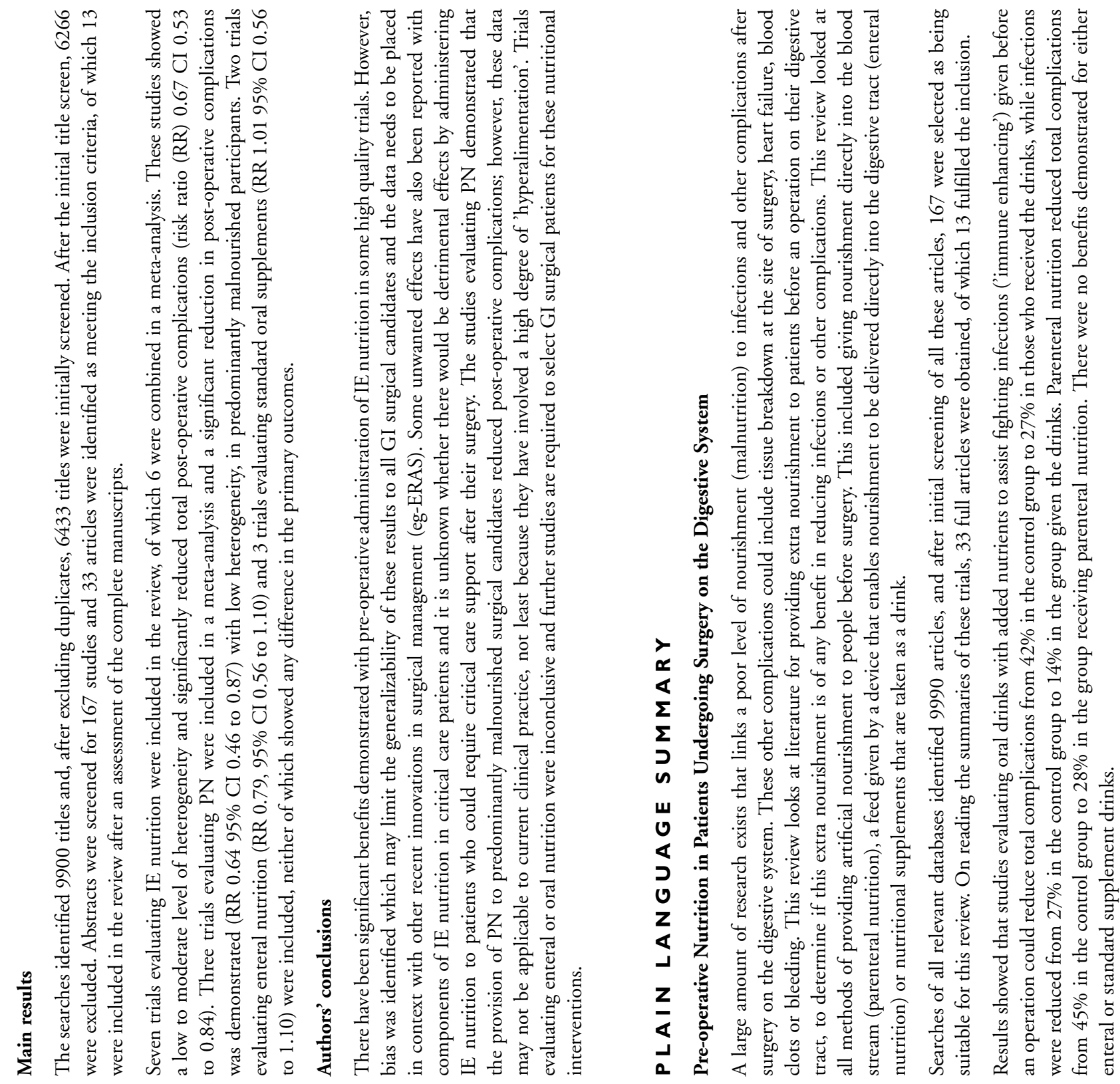

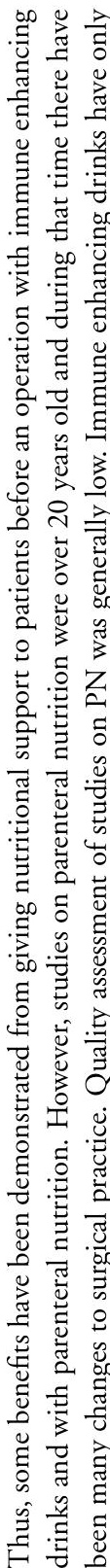




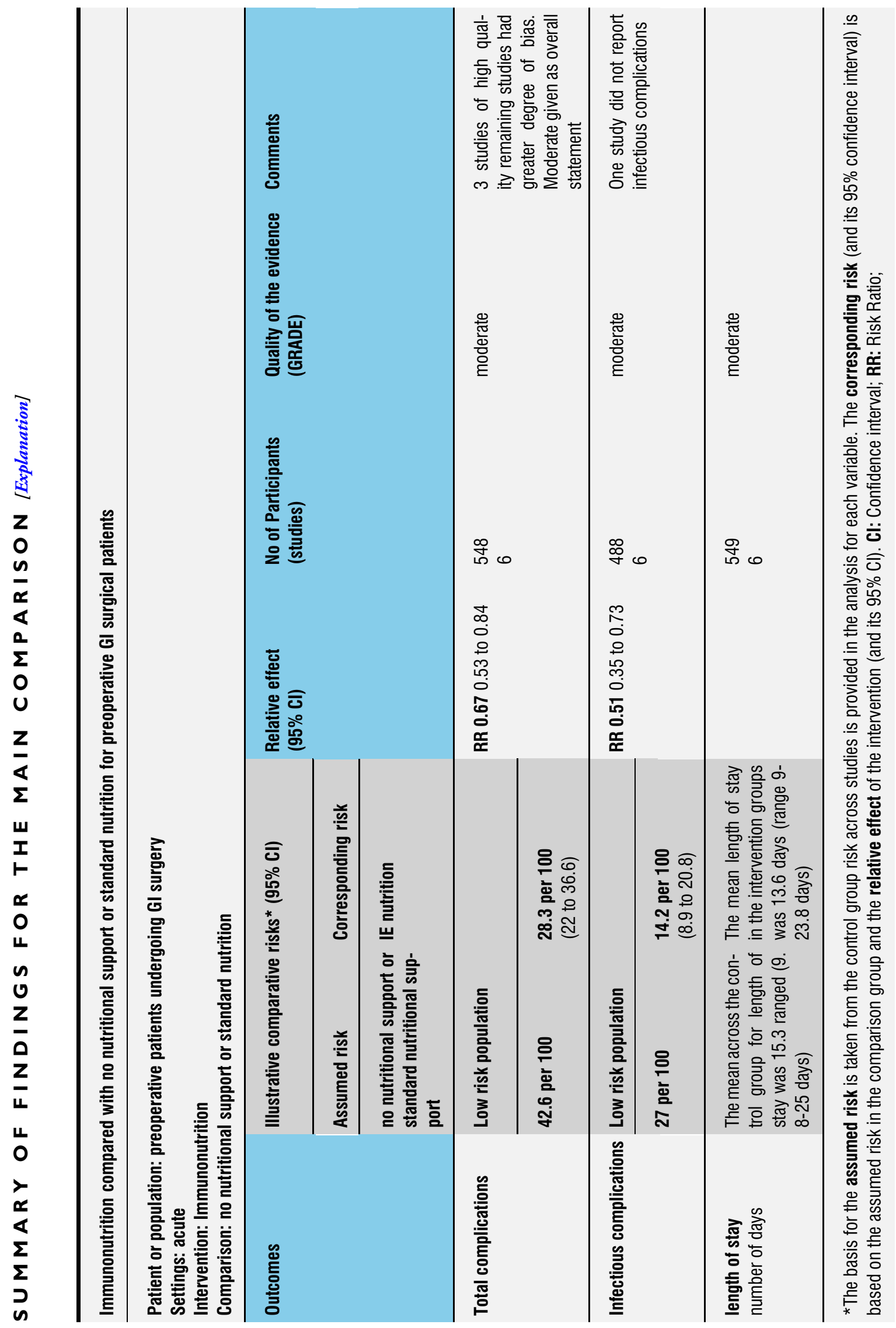

Pre-operative Nutrition Support in Patients Undergoing Gastrointestinal Surgery. (Review)

Copyright $\odot 2012$ The Cochrane Collaboration. Published by John Wiley \& Sons, Ltd. 


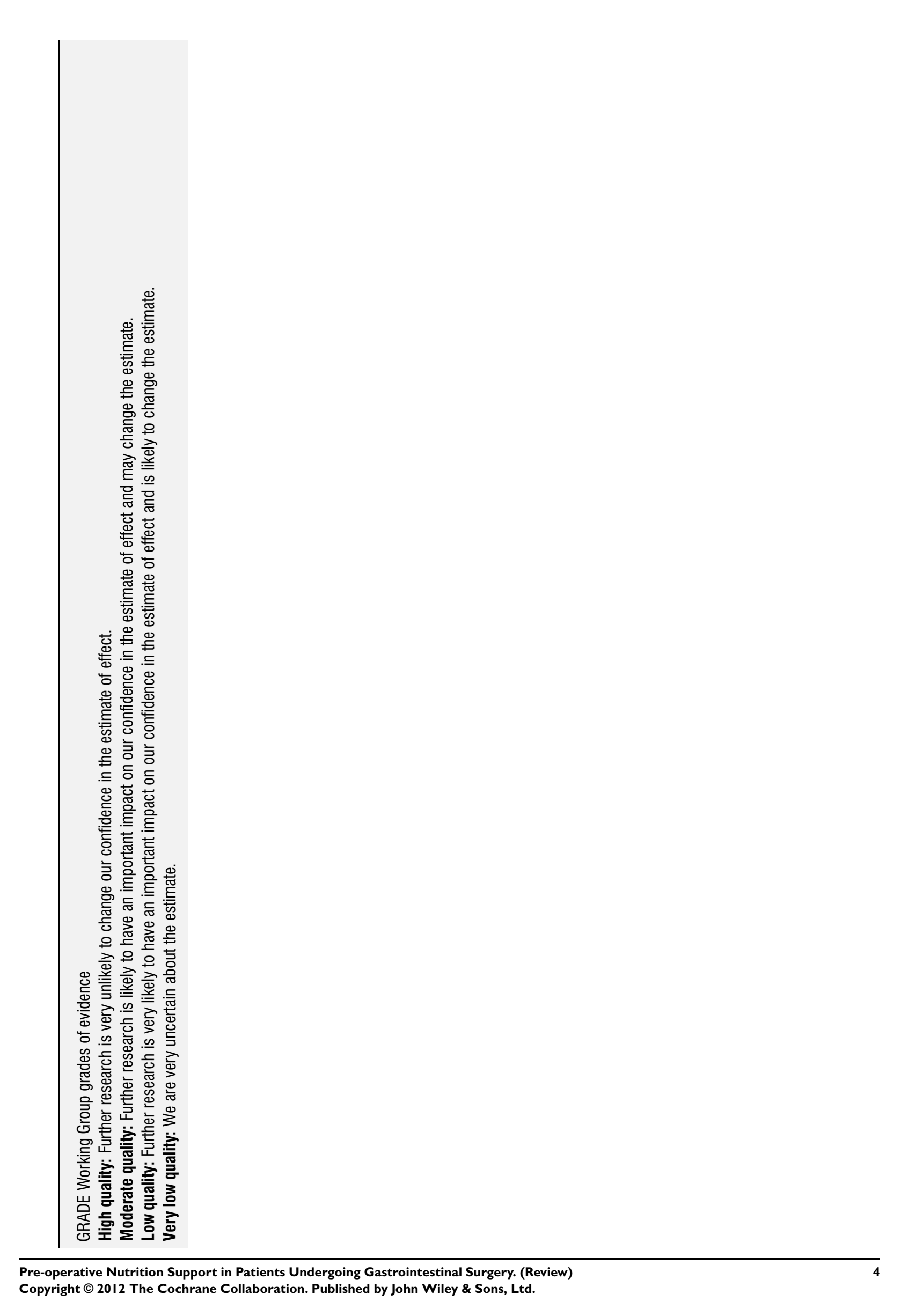




\section{B A C K G ROU N D}

\section{Description of the condition}

Pre-operative GI surgical patients who are at risk of malnutrition have an increased rate of mortality, morbidity and length of stay (Correira 2003; Barbosa-Silva 2005; Schiesser 2009). Fourteen percent of patients admitted for elective GI surgery have been found to be at risk of malnutrition, and of these, $40 \%$ suffered from post-operative complications, which was significantly greater than for those who were well nourished (Schiesser 2008). Poor nutritional status in preoperative patients has been well documented; it has been observed that $9 \%$ of patients undergoing elective GI surgery had a body mass index indicating under-nutrition, 54\% had lost weight unintentionally in the six months prior to surgery and $17 \%$ had lost more than $10 \%$ of their body weight in the same period, which is clinically significant (Fettes 2002).

Malnutrition is a well recognised problem in patients undergoing GI surgery; indeed, a recent UK survey $40 \%$ of patients with GI disease were reported to be at risk of malnutrition compared to $28 \%$ of all hospital admissions (Russell 2008). It has been demonstrated that poor nutritional status detrimentally affects post-operative outcome in patients undergoing colorectal surgery (Schwegler 2010). Since malnutrition may be detrimental to GI surgical outcomes, strategies aimed at addressing this have been evaluated. In prospective studies that have evaluated nutritional interventions in surgical patients some positive effects have been demonstrated for the use of enteral nutrition (Beier-Holgersen 1996) and for the use of oral sip feeds post-operatively (Keele 1997). In a consensus review of Enhanced Recovery After Surgery (ERAS), it was recommended that patients receive carbohydrate loading 24 hours pre-operatively and nutritional supplements, from the day of surgery, until oral intake is achieved (Lassen 2009). However, In the period prior to hospital admission or more than 24 hours pre-operatively there is a lack of consensus regarding the provision of nutritional support for weight losing patients or those who are malnourished.

\section{Description of the intervention}

Nutritional support intervention includes nutritional formulations that are used for medical purposes administered via the oral, enteral or parenteral route. For this review nutritional support intervention refers to mixed formulas containing macro and micronutrients with or without immunomodulating components.

\section{How the intervention might work}

The presence of malnutrition can contribute to a poor clinical outcome by affecting body structure, function, physical and psychological health (Stratton 2003). Malnutrition has been shown to be a significant prognostic indicator for post-operative complications (Sungurtekin 2004; Sorensen 2008), which significantly increases length of hospital stay (Leung 2009). Correcting malnutrition preoperatively in surgical patients to decrease post-operative morbidity and mortality may therefore be beneficial. When nutritional support has been instigated in malnourished patients, positive effects on anthropometry, clinical outcomes, and cost effectiveness have been demonstrated (Smedley 2004; Beier-Holgersen 1996). Benefits from the provision of nutritional intervention have also been demonstrated in well nourished cohorts without any direct effect on nutritional status measurements. This implies that there are physiological benefits to nutrition intervention not necessarily with improvements in anthropometric measurements, which may include improved immune, respiratory and cardiac function, along with improved wound healing and mobility (Akbarshahi 2008; Clark 2000).

\section{Why it is important to do this review}

ERAS is becoming increasingly common in the management of patients undergoing GI surgical. ERAS includes recommendations on post-operative nutritional management and feeding with preoperative carbohydrate loading (Lassen 2009). However, there is no consensus regarding nutritional intervention in the period preceding hospital admission for patients admitted for elective GI surgery.

\section{O B J E C T I V E S}

Primary objective

To evaluate if nutritional support intervention by any route prior to surgery improves clinical outcomes for elective GI surgical patients.

Secondary Objectives

To determine if nutritional support interventions provide any benefit to nutritional intake or nutritional status prior to elective GI surgery.

\section{METHOD S}

\section{Criteria for considering studies for this review}

Types of studies 
Published randomised controlled trials, conference abstracts of RCTs where sufficient data can be obtained.

\section{Types of participants}

All non- emergency GI surgical patients.

\section{Types of interventions}

Nutrition support intervention by any route using any nutritional formulation containing both macro and micronutrients. Studies were included if the nutritional formulation had a carbohydrate, fat and nitrogen source with vitamins and minerals administered over any time (up to 3 months prior to surgery to 24 hours pre-operatively). Studies were included if they had manipulated dietary intake to increase calories and protein. Studies were excluded if they were evaluating a single nutrient or IE agent or any combination of nutritional components that did not meet the inclusion criteria.

\section{Types of outcome measures}

\section{Primary outcomes}

1. Complications

Infective - including pneumonia, wound infections, abdominal abscess.

Non-infective - including anastomotic leak, wound dehiscence, organ failure or thromboembolism

2. Length of hospital stay

\section{Secondary outcomes}

1. Nutritional aspects including weight, anthropometric measurements, hand grip strength and subjective global assessment

2. Quality of life (including patient reported outcomes)

3. Within group and between group changes in macro nutrient (calories and protein/nitrogen) intake

4. Biochemical parameters including albumin, prealbumin and $\mathrm{C}$ reactive protein

5. 30 day perioperative mortality

6. Adverse effects from feed and route of feeding

All outcomes will be included up to 3 months post-operatively

\section{Search methods for identification of studies}

\section{Electronic searches}

RCTs were identified by searching a number of databases including all EBM Reviews (Cochrane DSR, ACP Journal Club, DARE, CCTR, CMR, HTA and NHSEED) MEDLINE, EMBASE, AMED, British Nursing Index Archive using OvidSP to run a search on each database separately then exclude duplicates. Detailed search strategy is shown in Appendix 1. The searches were initially run in March 2011 and subsequently updated in February 2012

\section{Searching other resources}

Reference lists of the articles selected were hand searched for the review and we contacted authors of any conference abstracts if further data were required.

\section{Data collection and analysis}

Data collection will be undertaken by two reviewers and then with the use of Revman (version 5.1, Cochrane Collaboration) will be displayed in the included and excluded studies section. Data analysis will be performed using the Revman (version 5.1, Cochrane Collaboration).

\section{Selection of studies}

Two review authors assessed the title and abstract to determine relevance and eligibility. All papers failing to meet the eligibility criteria were excluded. If there was insufficient information in the title and abstract, then the article was obtained for clarification. The review authors assessed the full text of all the papers and extracted data from those studies meeting the inclusion criteria. We planned to translate any non-English articles before assessment, if needed. A third review author was available to be called upon to resolve any conflicts in study selection.

\section{Data extraction and management}

A data collection form was devised that facilitated data collection from the articles. This form allowed eligibility to be assessed by linking the studies directly to the research question. The data extraction form was piloted and modified as required. Two reviewers undertook the process of data extraction independently and any discrepancies were discussed with a third reviewer. The following information was recorded for each trial:-

- Year of publication, country of origin, source of funding and number of participants.

- Details of participants including proportion of malnourished patients (defined by body Mass index less than $20 \mathrm{~kg} / \mathrm{m}^{2}$, weight loss greater than $10 \%$ in the previous 3-6 months, subjective global assessment or nutrition risk derived from a validated tool).

- Number of participants, age, type of surgery, perioperative management (ERAS or traditional), gender, diagnosis (noting proportion of cancer and non-cancer diagnosis).

- Details of type intervention (nutritional substrate with or without IE agents), route of intervention (oral, enteral or 
parenteral) and length of time on intervention, daily volume of nutritional substrate delivered.

- Details of primary and secondary outcomes.

\section{Assessment of risk of bias in included studies}

We rated the quality of each trial in the following areas; random sequence generation, allocation concealment, blinding, complete outcome data, selective outcome reporting and other sources of bias using the Cochrane Collaboration's tool New Reference.

\section{Measures of treatment effect}

The estimates of effect of an intervention were expressed as risk ratios together with $95 \%$ confidence intervals.

\section{Unit of analysis issues}

For dichotomous outcomes, estimates of effect of an intervention was expressed as risk ratios together with $95 \%$ confidence intervals. Continuous outcomes were expressed using mean differences and standard deviations to summarise the data for each group.

\section{Dealing with missing data}

Authors were contacted for abstracts and missing data where possible.

\section{Assessment of heterogeneity}

Clinical heterogeneity was assessed by examining the type of participants, interventions and outcomes in each study. Meta-analyses were only conducted if there were studies reporting similar comparisons for the outcome measures.

\section{Assessment of reporting biases}

Funnel plots were to be used to evaluate publication bias if appropriate.

\section{Data synthesis}

Meta-analyses were only conducted on studies reporting similar comparisons for the same outcome measures.

\section{Subgroup analysis and investigation of heterogeneity}

Sub group analyses were to be undertaken on studies including malnourished participants, participants with cancer and without cancer, elective versus semi-elective surgery, those that state the use of an ERAS protocol and route of feeding if data allowed. The studies included did not facilitate these sub group analyses.

\section{Sensitivity analysis}

Planned sensitivity analyses were to be undertaken to examine the difference in the quality of the studies and to examine the difference in studies conducted before and after 1990. This date was used because there have been advances in artificial feeding since 1990, including changes in technology, line care, feeding tubes and the type and amount of enteral and parenteral nutrition delivered Braunschweig 2001. Sensitivity analysis was also planned on studies that used an ERAS protocol, if appropriate. The studies included did not facilitate this.

\section{RES U L T S}

\section{Description of studies}

See: Characteristics of included studies; Characteristics of excluded studies.

See characteristics of included studies and characteristics of excluded studies. The searches were initially run in March 2011 and subsequently updated in February 2012. There were 13 randomised controlled trials identified from the literature searches that were included in the final analyses.

\section{Results of the search}

The results of the search are shown in Figure 1. 
Figure I. summary of literature review

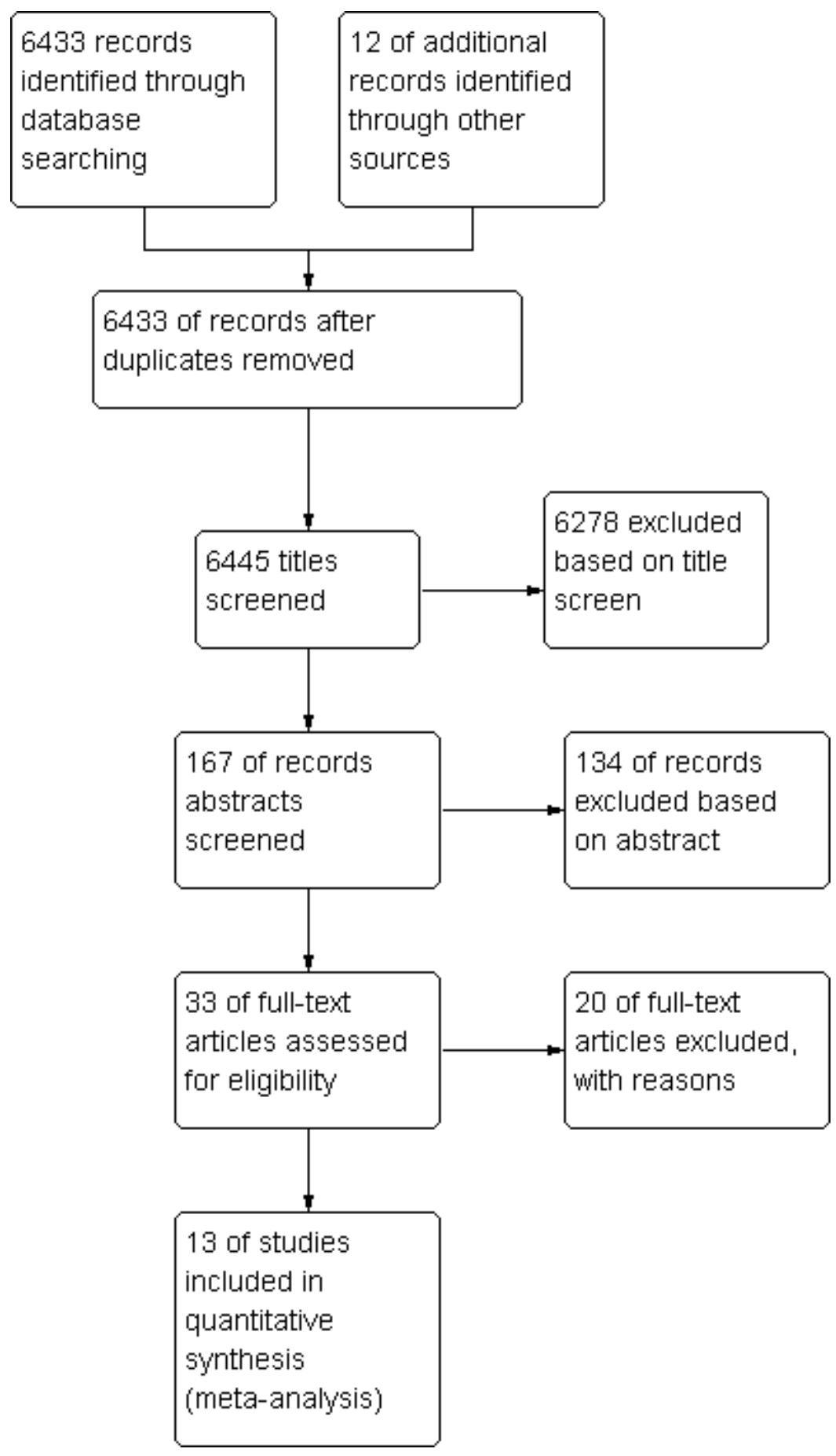




\section{Included studies}

From the included studies, three evaluated pre-operative PN Muller 1982, Von Meyenfeldt 1992 and Smith 1988, two included data on pre-operative standard enteral nutrition, Von Meyenfeldt 1992 and Gunerhan 2009, seven evaluated pre-operative IE nutrition Braga 2002a, Gianotti 2002, McCarter 1998, Okamoto 2009, Gunerhan 2009 ,Xu 2006; Braga 2002b and three evaluated pre-operative standard oral supplements Smedley 2004, Burden 2011 and MacFie 2000.

Braga 2002a included a comparison of pre-operative standard oral nutritional supplements compared to no nutrition, although the data were dichotomous thus not included in the meta-analysis. Smedley 2004 and MacFie 2000 reported data as counts of complications and Burden 2011 had data (unpublished) in the same format to allow an analysis to be undertaken. Gunerhan 2009 published data as counts in the cohort so was not included in the meta-analysis for IE nutrition as the majority of trials published dichotomous variables. In studies that included multiple comparisons which fell into two of the above categories, the data have been included in the appropriate analyses if possible (Braga 2002a, Von Meyenfeldt 1992).

There were a total of 1192 participants included in the analyses of the trials whose data were relevant to pre-operative nutritional support. There were 260 participants included in trials of PN, 120 participants included trials of enteral nutrition, 549 included in trials on IE nutrition and 263 participants included in trials for standard oral nutritional supplements.

Data were collected on methodology, location of surgery, types of participants, details of nutritional substrates, administration and outcomes from each study. Additional unpublished data were obtained from one study Burden 2011 to allow analysis with other trials (data were obtained on the primary outcome as counts or rates within the group, as data were published as dichotomous variables). The dates of included studies ranged from 1982-2011; a PN study was the earliest to be published on this topic Muller 1982. Mandatory for this review was that trials published data on pre-operative nutritional support where the post-operative management was similar in each group. The 13 trials included all published data on pre-operative nutrition compared with: either the absence of nutrition or an alternative nutritional formula. From the trials included, ten included data on participants with a malignant pathology. In one trial, $66 \%$ of participants had a malignancy pathology Smedley 2004 and details of pathology were not reported in two studies MacFie 2000, Smith 1988. Two trials included participants who had colorectal surgery Braga 2002a, Burden 2011, one reported participants who had gastric surgery Okamoto 2009, and three reported lower GI surgery Smedley 2004, Von Meyenfeldt 1992, Xu 2006. Patients undergoing either upper and lower GI surgery were included by Muller 1982, Smith 1988, Gianotti 2002, Gunerhan 2009, Braga 2002b and MacFie 2000.

Nutritional status of participants was reported in ten of the trials, four included malnourished patients Smith 1988, Von Meyenfeldt 1992, Gunerhan 2009,Braga 2002b. Between 30$60 \%$ of participants were malnourished in three trials Muller 1982, Burden 2011,Smedley 2004 and less than 25\% of participants were malnourished in three further trials Braga 2002a, MacFie 2000, McCarter 1998. One trial excluded malnourished patients Gianotti 2002 and the remaining trials did not report nutritional status Xu 2006, Okamoto 2009. Interestingly, all trials used different methods to assess nutritional status Table 1 .

All the PN trials administered nutrition for 10 days pre-operatively and volumes administered exceeded current recommendations for macro-nutrients Muller 1982 Smith 1988, Von Meyenfeldt 1992. In the seven trials on IE nutrition, $1000 \mathrm{mls}$ of the substrate was administered for five days in two trials Braga 2002a and Gianotti 2002 for seven days in five trials McCarter 1998, Okamoto 2009, Xu 2006, Gunerhan 2009,Braga 2002b 750mls of IE nutrition was administer in trials by Okamoto 2009, McCarter 1998 and volume was individually determined in trials by $\mathrm{Xu} 2006$ and Gunerhan 2009. The same IE supplement was used in six trials with additional arginine $(12.5 \mathrm{~g} / \mathrm{L})$, omega $3(3.3 \mathrm{~g} / \mathrm{L})$ and RNA $(1.2 \mathrm{~g} / \mathrm{L})$ :- the remaining trial used a IE substrate containing $3.4 \mathrm{~g} /$ L of omega 3 and 26.5g/L of arginine McCarter 1998. In the oral supplement trials that evaluated standard formulas, two trials administered 400mls of supplement daily Burden 2011 and MacFie 2000 and in one trial participants were advised to take drinks ad libitum Smedley 2004; all these trials used the same supplement and all were conducted in the UK. The mean energy value consumed from supplements was 542 and 507 kilocalories in Smedley 2004 and MacFie 2000 respectively. Two trials compared enteral nutrition pre-operatively with no artificial nutritional support Von Meyenfeldt 1992 and Gunerhan 2009.

All trials included post-operative complications as an outcome, although the definition applied to complications varied considerably. In some trials, post-operative complications were defined as infectious and non infectious complications Braga 2002a, Gianotti 2002, Burden 2011 and Smedley 2004. Other trials outlined definitions used for complications in the publication Muller 1982, Smith 1988, Von Meyenfeldt 1992 and Okamoto 2009. Definitions for complications were not included in the remaining trials MacFie 2000, Gunerhan 2009, McCarter 1998 and Xu 2006. Biochemistry (albumin, transferrin or prealbumin) were recorded in seven trials Muller 1982, Smith 1988, Von Meyenfeldt 1992,Braga 2002b,Gunerhan 2009, Okamoto 2009 and MacFie 2000. Other outcomes included in the trial are listed in Table 2. All adverse events reported in the trials are given in Table 3.

Pre-operative Nutrition Support in Patients Undergoing Gastrointestinal Surgery. (Review) 


\section{Excluded studies}

Twenty studies did not meet the inclusion criteria and the details of these are given in the table of excluded studies section. From the trials identified it was determined that 13 fitted our inclusion criteria (see table of included studies).

\section{Risk of bias in included studies}

\section{Allocation}

Sequence generation was described well in six of the included trials Braga 2002a,Braga 2002b Burden 2011, Gianotti 2002, Smedley 2004 and Smith 1988, allocation concealment was described in Burden 2011, Smedley 2004 and Smith 1988. The method of sequence generation and allocation concealment was not reported in the other included trials.

\section{Blinding}

Blinding was only undertaken in two of the trials Braga 2002a and McCarter 1998. In some instances it would be difficult to blind the intervention especially where parenteral was compared with enteral nutrition. The remaining studies did not report any blinding of the researchers or the participants taking part, thus introducing a high risk of bias.

\section{Incomplete outcome data}

A number of trials reported a high risk or unclear risk of attrition bias including Burden 2011, Gunerhan 2009, MacFie 2000, McCarter 1998, Muller 1982; Smedley 2004 . This was primarily due to participants being recruited who did not then have elective surgery and therefore were not included in the analysis. Nutritional intervention is a supportive therapy, so if participants do not then undergo surgery, postoperative complications can clearly not be evaluated. Post randomisation exclusions occurred in four trials for this reason Burden 2011, Smedley 2004 Muller 1982 and MacFie 2000. In four trials, participants were excluded for other reasons including GI bleeding, emergency surgery to relieve obstruction, uncontrolled blood sugar levels, minimum oral intake of the intervention, no diagnosis of a malignancy and some participants were excluded if they received postoperative enteral or parenteral nutrition Gunerhan 2009, Muller 1982, McCarter 1998, Smedley 2004.

\section{Selective reporting}

All of the trials included in the review reported at least one of the primary outcomes listed in the methodology section of this review.

\section{Other potential sources of bias}

Although some trials predominantly included participants with malignant pathology, they excluded patients who had received pre-operative chemotherapy, radiotherapy or immuno suppressive treatment Gianotti 2002, McCarter 1998; Gunerhan 2009 Braga 2002b. This will introduce external bias and thus affect the generalizability of the results.

Only a few trials specifically enrolled malnourished patients Braga 2002b, Gunerhan 2009,Von Meyenfeldt 1992,Smith 1988 and the majority of participants included in the trials reviewed were well nourished. Thus participants who would be most likely to benefit from nutritional support were not included in the majority of existing research. Perioperative surgical management has changed over the last decade with the advent of ERAS along with technological advances in the delivery, assessment and formulation of nutritional substrates, all of which may introduce temporal bias into the body of evidence. The risk of bias summary is given in Figure 2 and judgements about each risk of bias item presented as percentages across all included studies is shown in Figure 3. 
Figure 2. Risk of bias summary: review authors' judgements about each risk of bias item for each included study.

\begin{tabular}{|c|c|c|c|c|c|c|}
\hline & 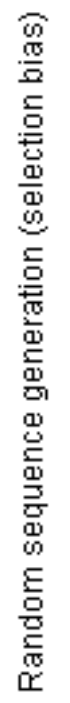 & 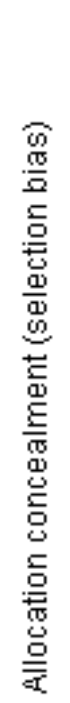 & 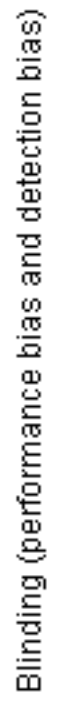 & 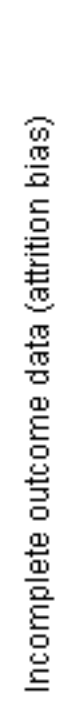 & 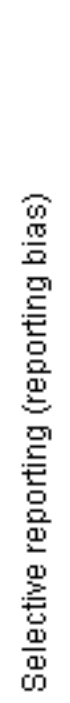 & 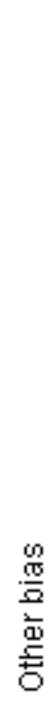 \\
\hline Braga 2002a & + & $?$ & $?$ & $\oplus$ & + & + \\
\hline Braga 2002b & + & $?$ & & $\oplus$ & + & $?$ \\
\hline Burden 2011 & + & $\odot$ & & - & + & $?$ \\
\hline Gianotti 2002 & + & $?$ & & $\oplus$ & + & $?$ \\
\hline Gunerhan 2009 & $?$ & $?$ & & - & $?$ & $?$ \\
\hline MacFie 2000 & $?$ & $?$ & & $?$ & + & $?$ \\
\hline McCarter 1998 & $?$ & $?$ & + & - & + & ? \\
\hline Muller 1982 & $?$ & $?$ & & $?$ & $?$ & \\
\hline Okamoto 2009 & $?$ & $?$ & & $\oplus$ & + & $?$ \\
\hline Smedley 2004 & + & $\oplus$ & & & + & \\
\hline Smith 1988 & $?$ & $\oplus$ & & $?$ & + & \\
\hline Von Meyenfeldt 1992 & $?$ & $?$ & & $\oplus$ & + & $?$ \\
\hline Xu 2006 & $?$ & $?$ & & + & $?$ & $?$ \\
\hline
\end{tabular}


Figure 3. Risk of bias graph: review authors' judgements about each risk of bias item presented as percentages across all included studies.

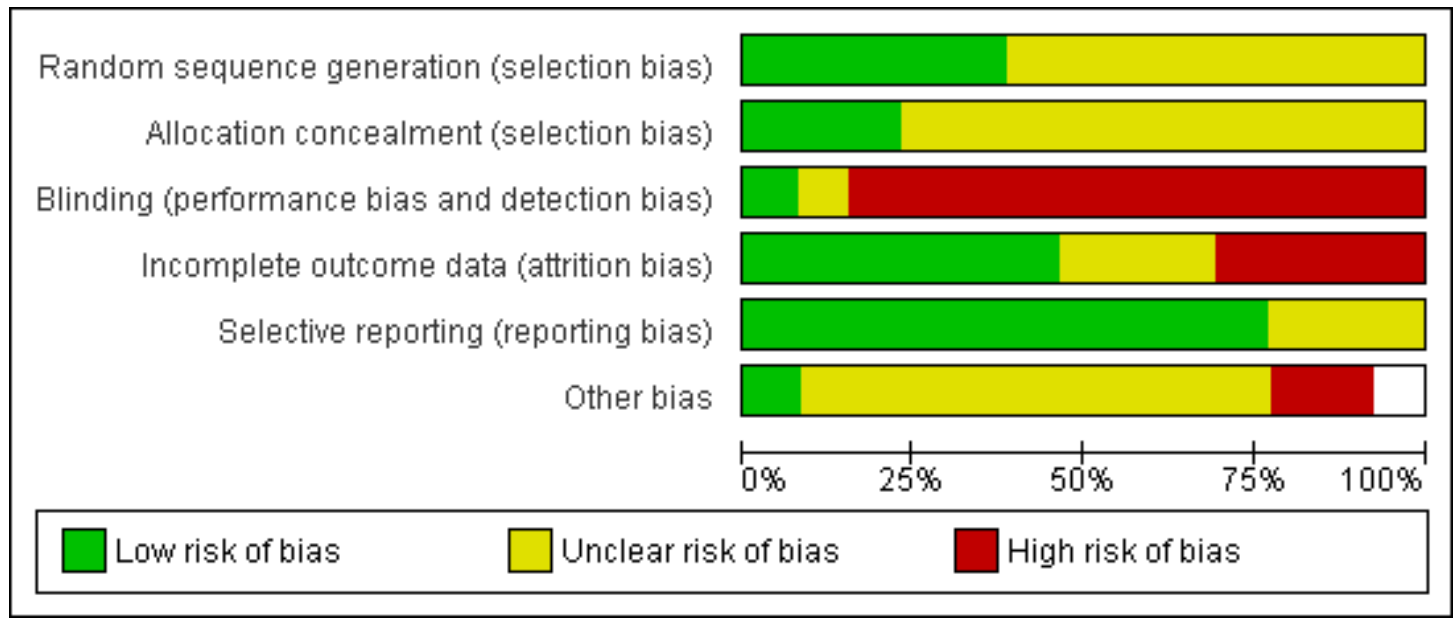

\section{Effects of interventions}

See: Summary of findings for the main comparison; Summary of findings 2; Summary of findings 3; Summary of findings 4 The analysis of the studies has been divided into IE nutrition trials, parenteral nutrition, enteral nutrition and oral standard nutritional formulas. The analysis for IE nutrition included noninfectious complications, infectious complications and length of hospital stay. The analysis compared all the IE pre-operative trials with no nutritional support or standard nutritional support and then looked at trials comparing IE nutrition with no nutrition, and then IE nutrition with standard nutritional support.
Immune-enhancing nutrition

There were seven trials Braga 2002a, Braga 2002b, Gianotti 2002, Gunerhan 2009, McCarter 1998, Okamoto 2009, Xu 2006 comparing IE nutrition to either no nutritional support or standard nutritional support, of which six Braga 2002a,Braga 2002b Gianotti 2002, McCarter 1998, Xu 2006; Okamoto 2009 were included in the mets analysis involving 548 participants Figure 4. Dichotomous data were analysed using risk ratios with Mantel-Haenszel in a fixed effects method. Absolute risk of a complication ranged from $42.6 \%(116 / 273)$ in the control group and $28.3 \%(78 / 275)$ in the intervention group and heterogeneity between the studies was low to moderate $\left(\mathrm{Chi}^{2}=7.73, \mathrm{P}=0.17\right)$ Analysis 1.1 . The relative effect was 0.67 (CI 0.53 to 0.84 ) for total complications. 
Figure 4. Forest plot of comparison: I All IE nutrition compared to no nutrition or standard nutrition, outcome: I.I Total complications.

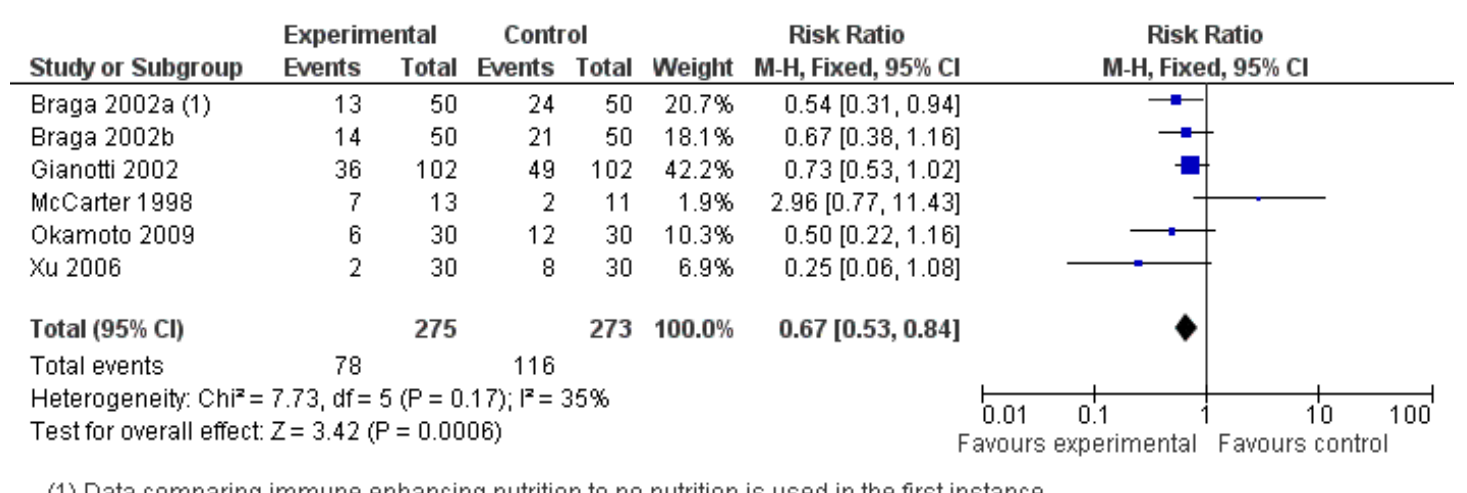

(1) Data comparing immune enhancing nutrition to no nutrition is used in the first instance.

Five trials (including 488 participants) reported infectious complications Figure 5 Analysis 1.2. The absolute risk for infectious complications ranged from $27 \%(68 / 243)$ in the control group to $14.2 \%$ in the intervention group $(35 / 245)$ and the relative risk was 0.51 (CI 0.35 to 0.73 ). The heterogeneity between these studies represented a moderate risk $\left(\mathrm{Chi}^{2}=5.2 .162, \mathrm{P}=0.23\right)$.

Figure 5. Forest plot of comparison: I All IE nutrition compared to control or standard nutrition, outcome: I.2 Infectious complications.

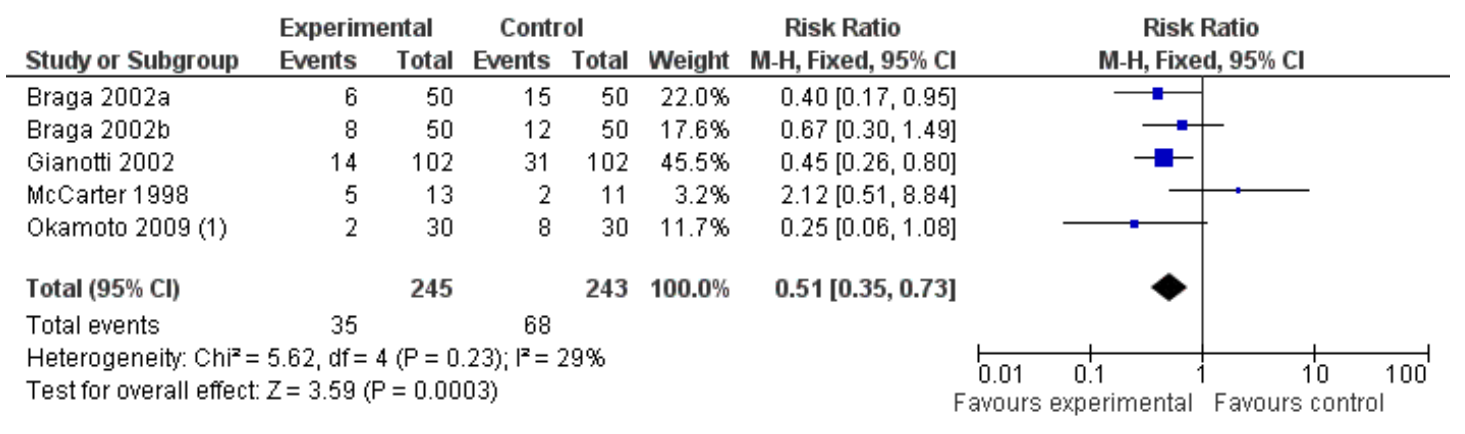

(1) $X u-$ not included as infections given as counts not a dichotomous variable

Six trials (549 participants) reported the mean length of stay Figure 6, Analysis 1.3 for all trials reporting this outcome for IE nutrition was15.3 (9.8-25) days in the control group and 13.6 (9-23.8) days in the intervention group an difference was -0.97 (CI -1.64 to $0.30)$ and heterogeneity for this outcome was $\left(\mathrm{Chi}^{2}=24.26, \mathrm{P}=\right.$ 0.0002 ) which represents a low level of heterogeneity. 
Figure 6. Forest plot of comparison: I All IE nutrition compared to control or standard nutrition, outcome: I.3 length of stay.

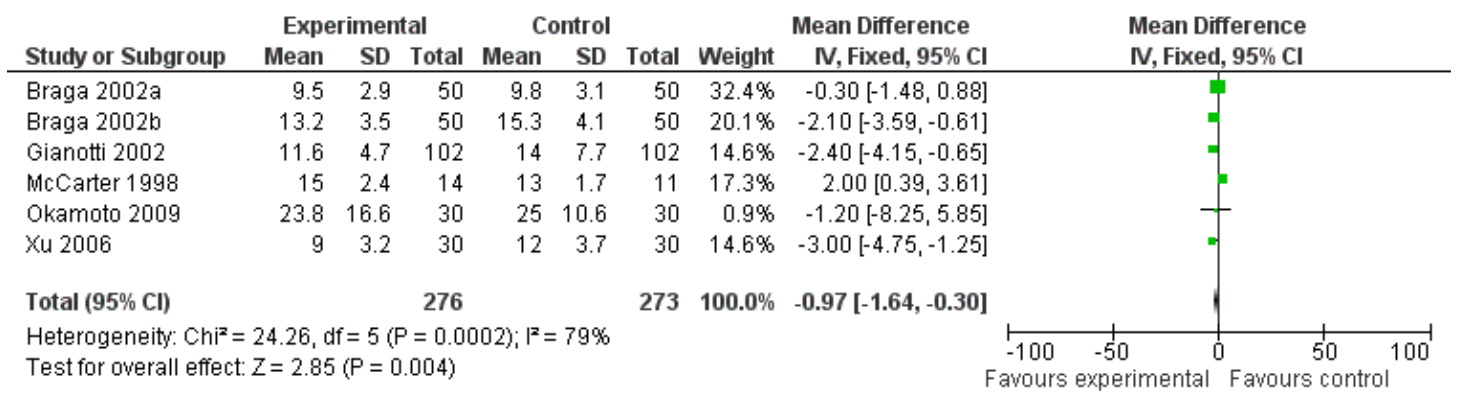

Immune-enhancing nutrition was then compared to standard nutritional supportFigure 7 Analysis 2.1, Figure 8, Analysis 2.2 Figure 9 Analysis 2.3 and no nutritional support Figure 10 Analysis 3.1, Figure 11 Analysis 3.2, Figure 12 Analysis 3.3.

Figure 7. Forest plot of comparison: 2 Preoperative IE nutrition compared to standard nutrition, outcome: 2.I Total complications.

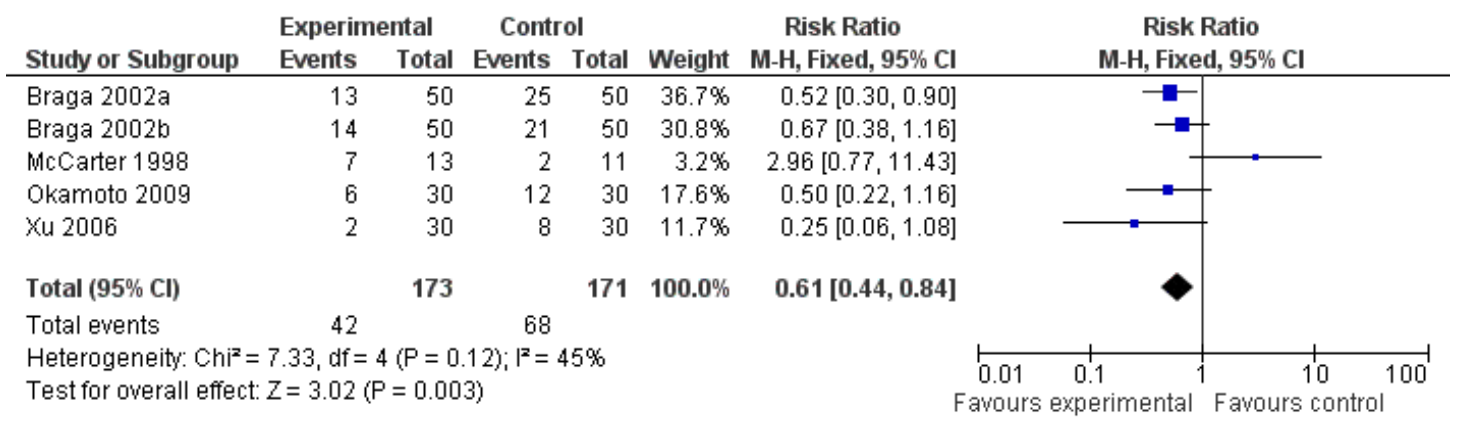

Figure 8. Forest plot of comparison: 2 Preoperative IE nutrition compared to standard nutrition, outcome: 2.2 Infectious complications.

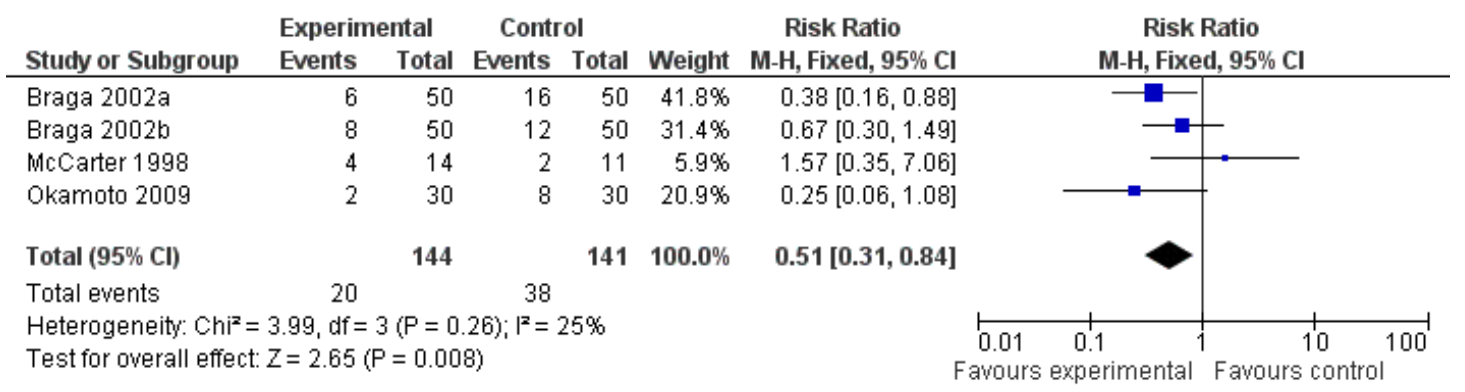

Pre-operative Nutrition Support in Patients Undergoing Gastrointestinal Surgery. (Review) 
Figure 9. Forest plot of comparison: 2 Preoperative IE nutrition compared to standard nutrition, outcome: 2.3 Length of stay.

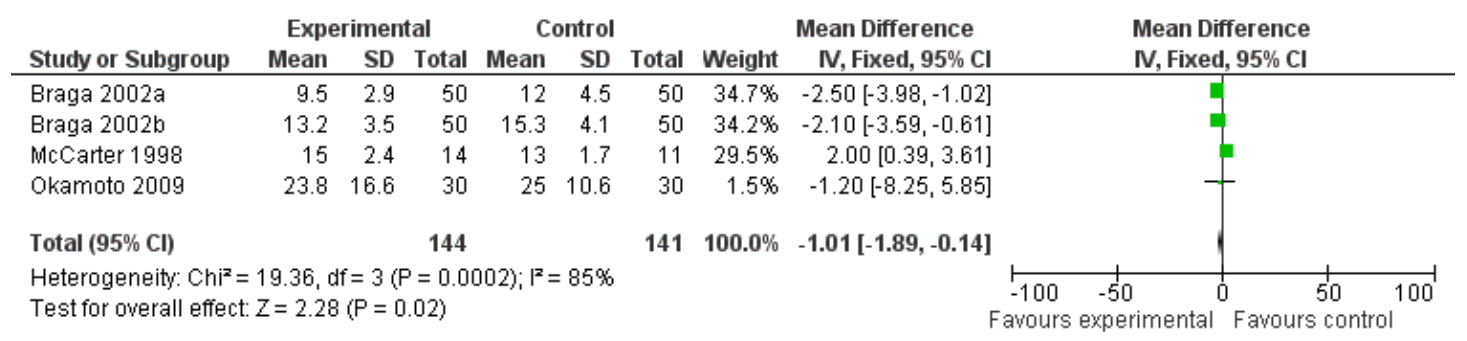

Figure 10. Forest plot of comparison: 3 Preoperative IE nutrition compared to no nutrition, outcome: 3. I Total complications.

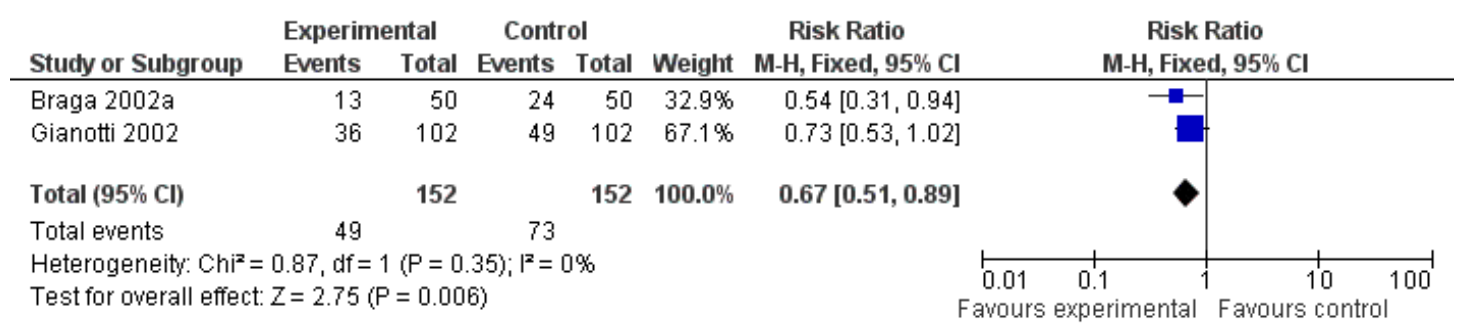

Figure I I. Forest plot of comparison: 3 Preoperative IE nutrition compared to no nutrition, outcome: 3.2 Infectious complications.

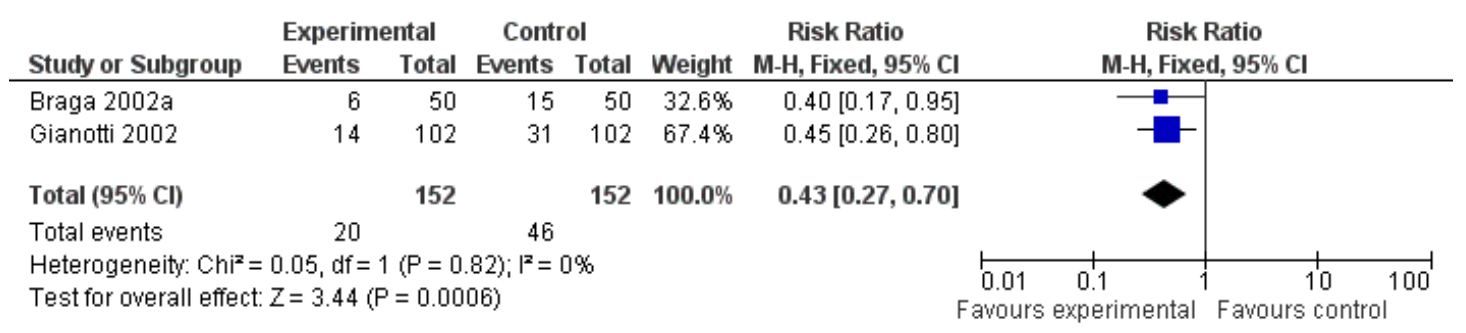


Figure I2. Forest plot of comparison: 3 Preoperative IE nutrition compared to no nutrition, outcome: 3.3 Length of stay.

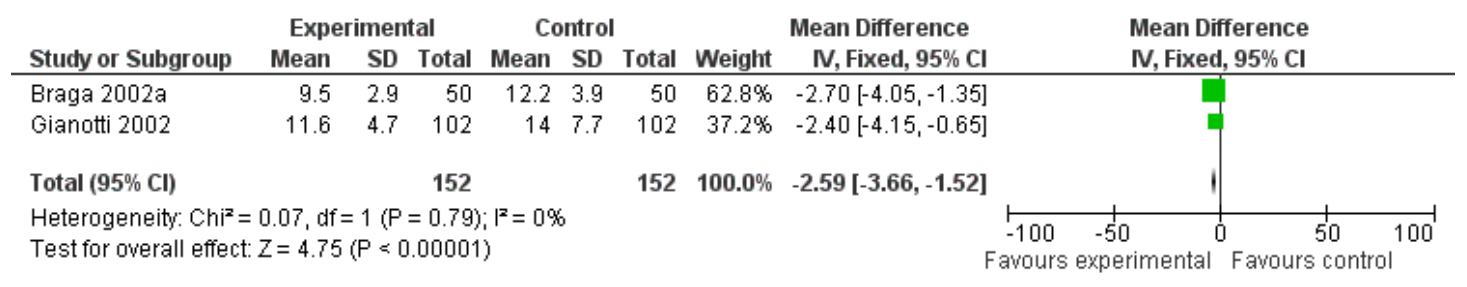

\section{Standard oral nutritional support}

Pre-operative oral nutritional support was compared to no nutritional support or dietary advice Burden 2011, Smedley 2004 and MacFie 2000, which included non-infectious complications and infectious complication reporting on 263 and 250 participants, respectively. Count data were analysed using risk ratios with MantelHaenszel in a fixed effects method. The absolute risk for non-infectious complications in the control group was $45.2 \%(62 / 137)$; in the intervention group $52.65 \%(60 / 126)$ and the relative effect was 1.06 (CI 0.82 to 1.36 ). For this outcome, heterogeneity was $\mathrm{Chi}^{2}=13.1, \mathrm{P}=0.001$, representing a high level of heterogeneity Figure 13 Analysis 4.1. For infectious complications the absolute risk was $43.5 \%(57 / 131)$ in the control group and $47.4 \%$ (56/ $119)$ in the intervention group. The relative effect was 1.09 (CI 0.83 to 1.42 ) and the heterogeneity was $\mathrm{Chi}^{2}=12.5, \mathrm{P}=0.002$ thus representing a high level of heterogeneity Figure 14 Analysis 4.2. Length of stay is shown in Figure 15 Analysis 4.3.

Figure 13. Forest plot of comparison: 4 Preoperative standard oral nutrition compared to no nutrition, outcome: 4.I Total complications.

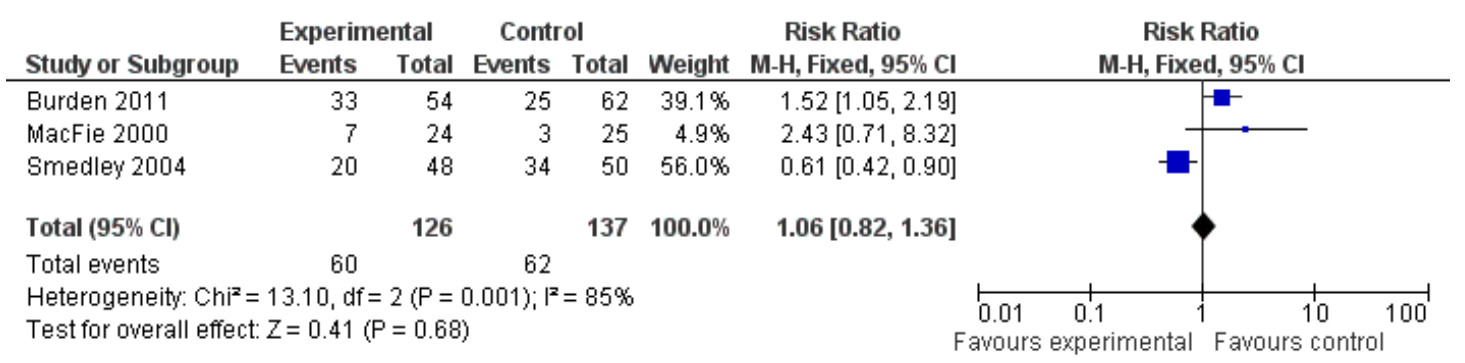

Figure 14. Forest plot of comparison: 4 Preoperative standard oral nutrition compared to no nutrition, outcome: 4.2 Infectious complications.

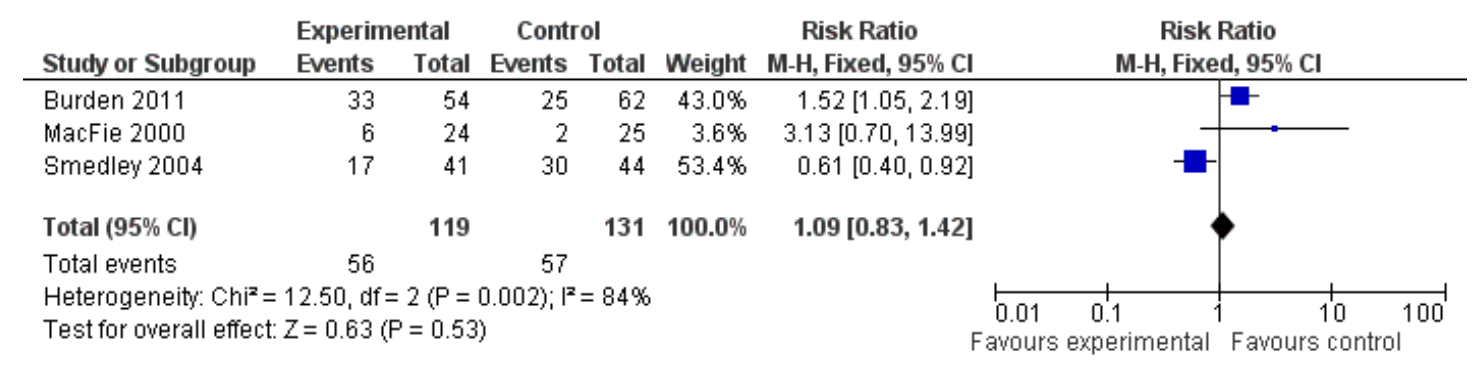

Pre-operative Nutrition Support in Patients Undergoing Gastrointestinal Surgery. (Review) 
Figure I5. Forest plot of comparison: 4 Preoperative standard oral nutrition compared to no nutrition, outcome: 4.3 Length of stay.

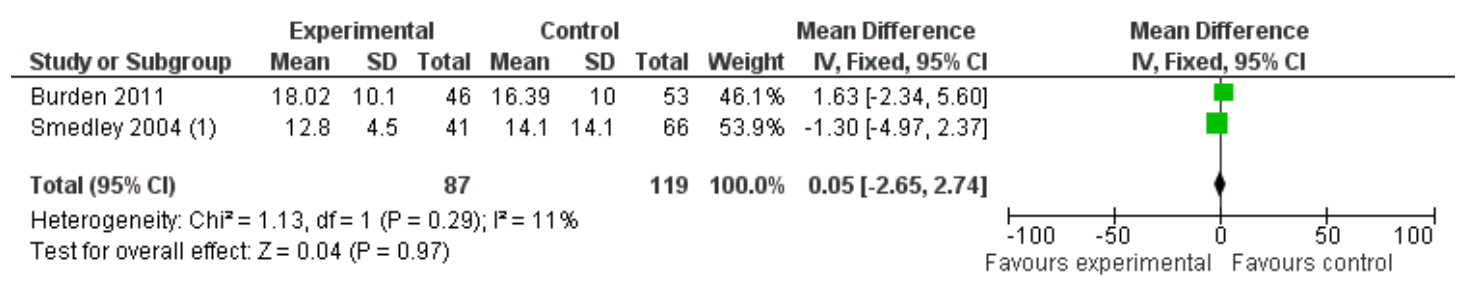

(1) Burden 2011- unpublished data used

\section{Enteral Nutrtional support}

Two trials that evaluated enteral nutrition compared to no artificial nutritional support Von Meyenfeldt 1992 and Gunerhan 2009; these trials included 120 participants who were all malnourished. Nutritional status was assessed using subjective global assessment Gunerhan 2009 and nutritional index Von Meyenfeldt 1992. However, both trials were rated as having a high risk of bias. Count data were analysed using risk ratios with Mantel-Haenszel in a fixed effect method. The absolute risk for total complications was $42 \%(35 / 59)$ in the control group and $40.7 \%$ (28/
$66)$ in the intervention groups and the relative effect was 0.79 (CI 0.56 to1.10). Heterogeneity for this outcome in the two trials was low $\left(\mathrm{Chi}^{2}=0.25, \mathrm{P}=0.62\right)$ Figure 16 Analysis 5.1. For infectious complications, the absolute risk in the control and intervention group was the same at $45 \%$ for the control (based on 29/59) and for the intervention group (based on 30/66). The relative effect was 1 (CI 0.69 to 1.44 ) and, again, heterogeneity for the two trials for this outcome was low $\left(\mathrm{Chi}^{2}=0.84, \mathrm{P}=0.36\right)$ Figure 17 Analysis 5.2 .

Figure 16. Forest plot of comparison: 5 Preoperative enteral nutrition compared to no nutrition, outcome: 5.I Total complications.

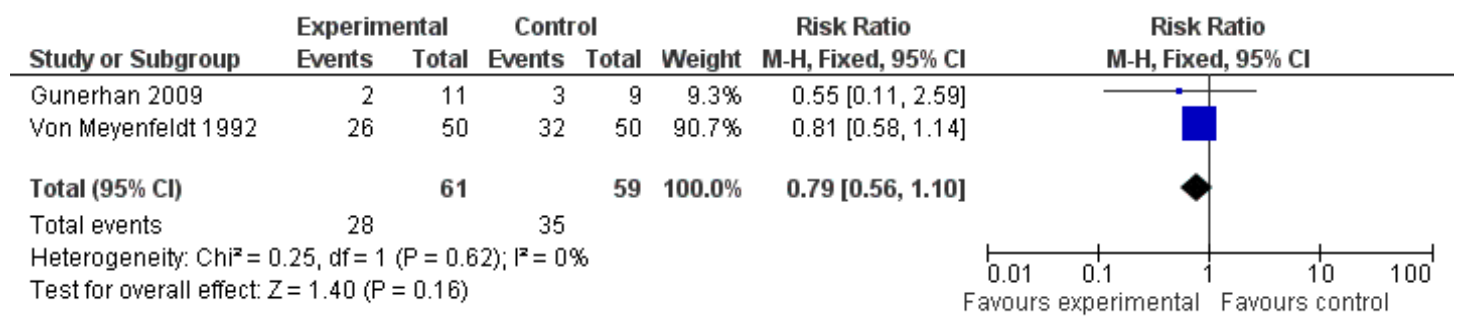

Figure 17. Forest plot of comparison: 5 Preoperative enteral nutrition compared to no nutrition, outcome: 5.2 Infectious complications.

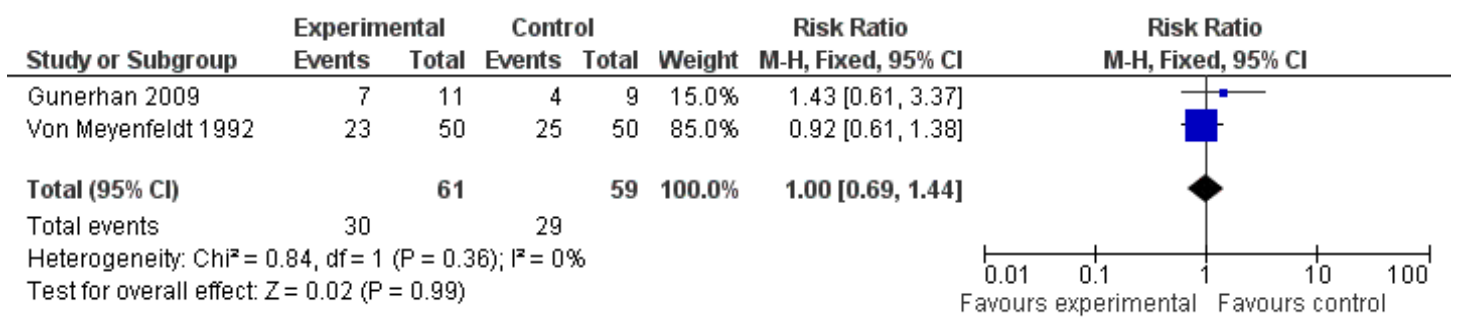

Pre-operative Nutrition Support in Patients Undergoing Gastrointestinal Surgery. (Review) 


\section{Parenteral nutritional support}

Parenteral nutrition was given preoperatively in three trials Smith 1988, Von Meyenfeldt 1992 and Muller 1982, including 260 participants with non-infectious complications reported as an outcome and 226 participants reported for infectious complications. Count data were analysed using risk ratios with Mantel-Haenszel in a fixed effects method. Absolute risk for non-infectious complication was 45.2 (57/126) for the control group and 28.9 (38/ 134) for the intervention group. Relative effect was 0.64 (CI 0.46 to 0.87 ) for non-infectious complications Figure 18 Analysis 6.1 and 0.94 (CI 0.80 to 1.10 ) for infectious complications Figure 19 Analysis 6.2. Heterogeneity between the three studies for total complications was low $\left(\mathrm{Chi}^{2}=1.16, \mathrm{P}=0.56\right)$ and for infectious complications was high $\left(\mathrm{Chi}^{2}=18.56, \mathrm{P}=0.0001\right)$. The trials evaluating $\mathrm{PN}$ pre-operatively were assessed as having a high risk of bias as these trials were all over 20 years old and clinical practices have now altered with improved delivery techniques, nutrient solutions, assessment and patient management.

Figure 18. Forest plot of comparison: 6 Preoperative PN compared to no nutrition, outcome: 6.2 Infectious complications.

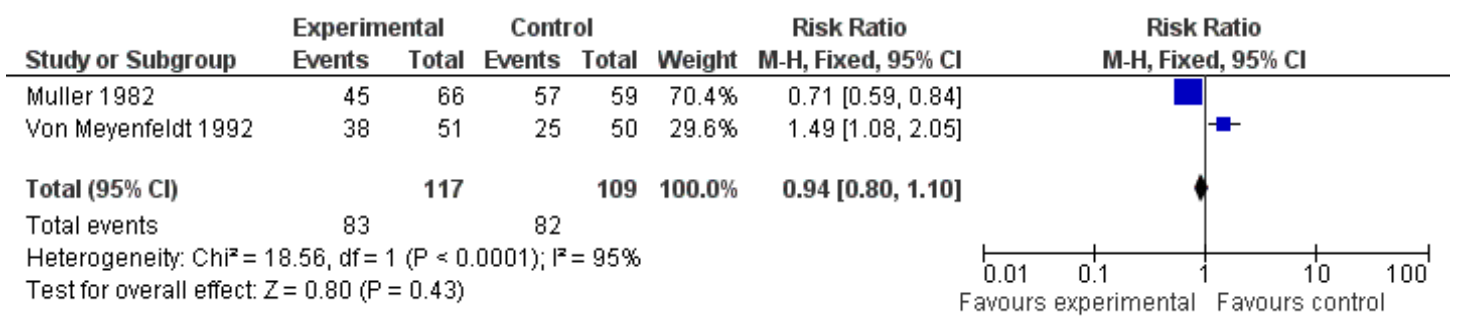

Figure 19. Forest plot of comparison: 6 Preoperative PN compared to no nutrition, outcome: 6.I Major complications.

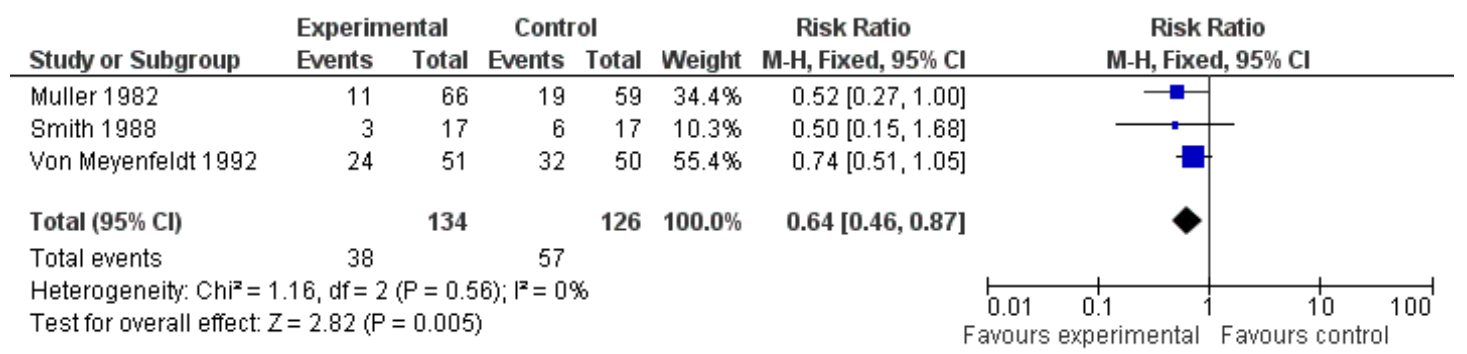




\section{Other outcomes}

The length of follow up in the trials for post-operative complications was only reported in one of the trials Gianotti 2002. Nutritional status parameters including anthropometry, handgrip strength or biochemistry were monitored in Muller 1982, Smith 1988 Gianotti 2002 Okamoto 2009; Xu 2006; Smedley 2004 MacFie 2000 Nutritional intake was reported in trials that evaluated oral supplements MacFie 2000, Smedley 2004, Burden 2011 and quality of life was only reported in two trials Smedley 2004 and MacFie 2000.

Funnel plots were not undertaken on any of the comparisons in the review as the number of trials in each of the analyses was too small to determine risk of publication bias. 


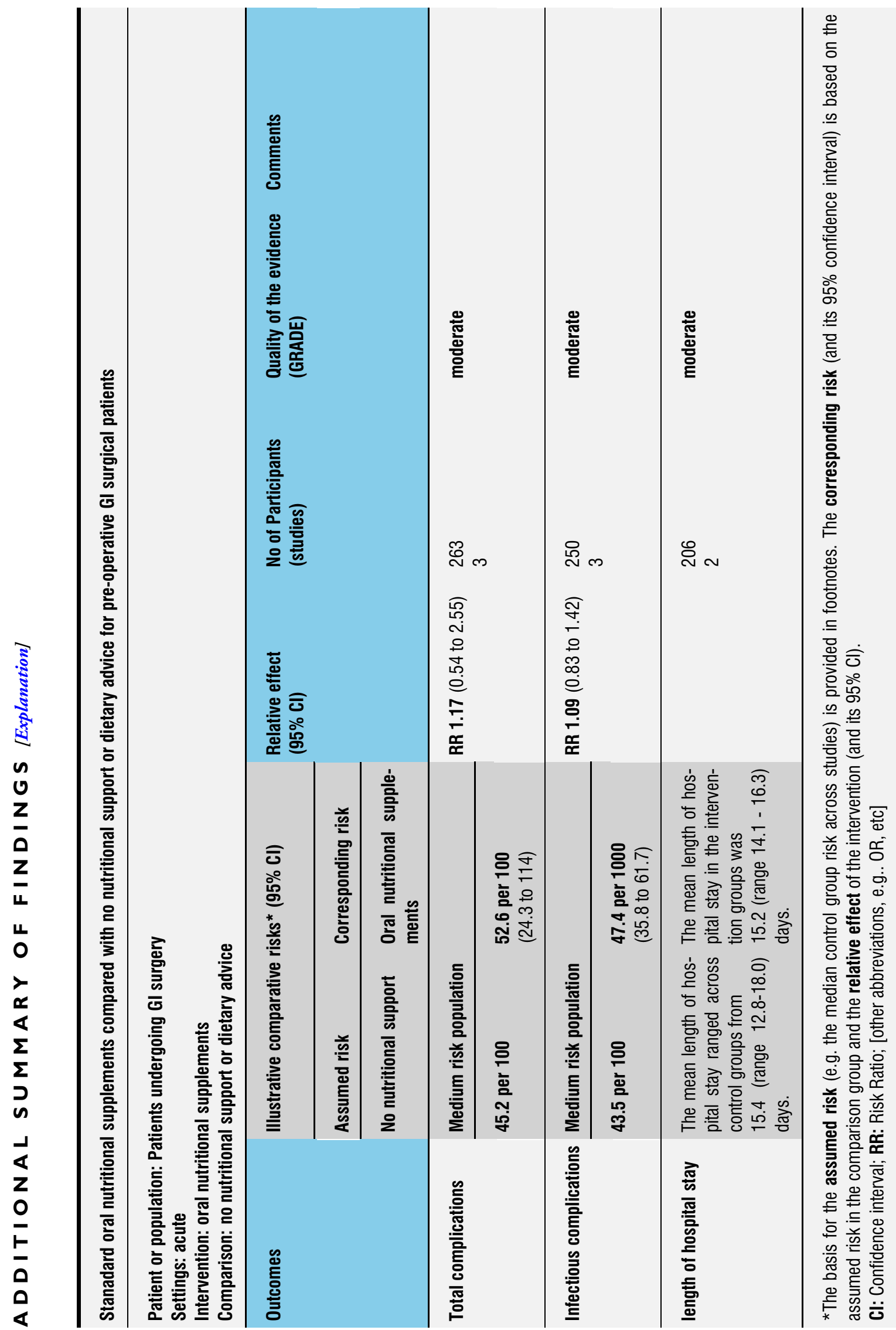

Pre-operative Nutrition Support in Patients Undergoing Gastrointestinal Surgery. (Review)

Copyright $\odot 2012$ The Cochrane Collaboration. Published by John Wiley \& Sons, Ltd. 
ن.

స్

竞 导

음

氜

잉

등 욱

잉

है

응 음

过

里

¿

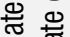

ह ह

क्ष

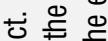

密.

$\leftarrow$ 잉

Ф 흥

풀 은 흥

엉 등

む)

등

엉 늉

을 हE

등 들

능 능

르를

음

ㅊㅀㅀ 뜽

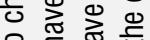

+ 드

궝유웅

일 칭

흠 吾.

궁 는

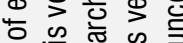

\& 덩 원?

ㅎㅠㅎㅀ

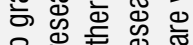

윽 힌 흑 인

은히히 히

品站

는

홍 끌

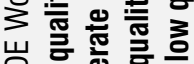

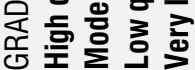

Pre-operative Nutrition Support in Patients Undergoing Gastrointestinal Surgery. (Review)

Copyright $\odot 2012$ The Cochrane Collaboration. Published by John Wiley \& Sons, Ltd. 


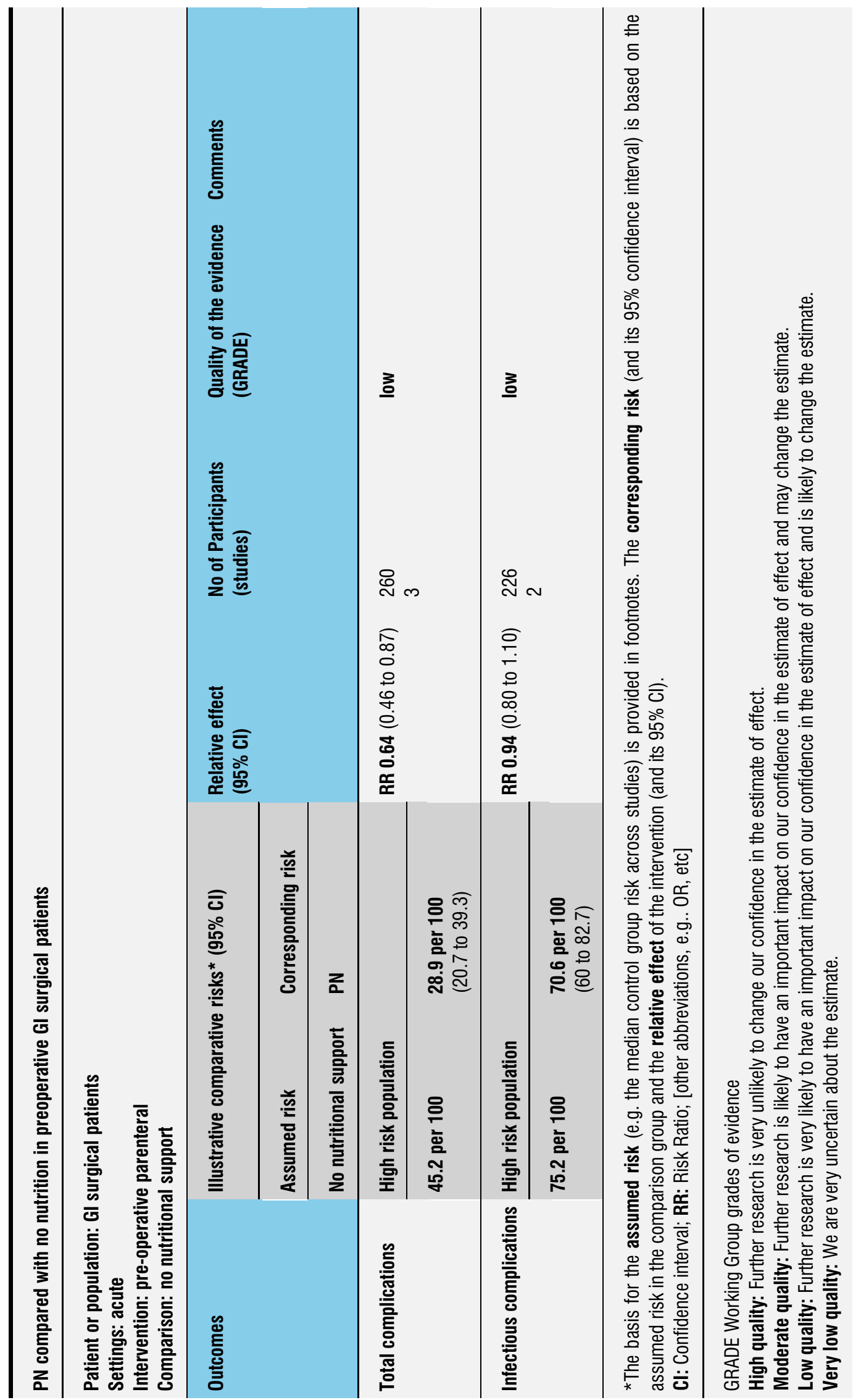

Pre-operative Nutrition Support in Patients Undergoing Gastrointestinal Surgery. (Review)

Copyright @ 2012 The Cochrane Collaboration. Published by John Wiley \& Sons, Ltd. 


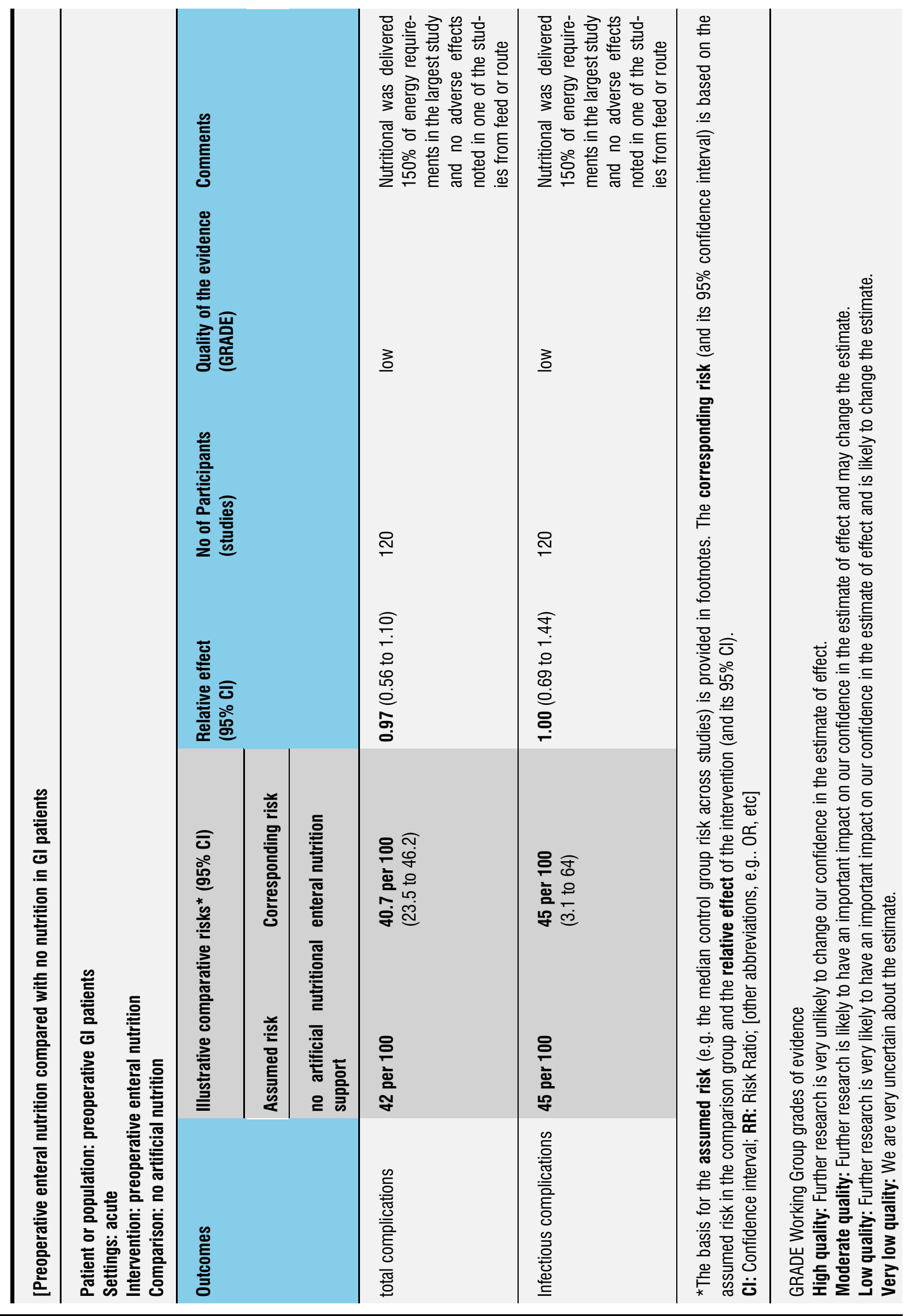

Pre-operative Nutrition Support in Patients Undergoing Gastrointestinal Surgery. (Review)

Copyright @ 2012 The Cochrane Collaboration. Published by John Wiley \& Sons, Ltd. 
Copyright ( 2012 The Cochrane Collaboration. Published by John Wiley \& Sons, Ltd. 


\section{DISCUSSION}

\section{Summary of main results}

Thirteen studies that met the inclusion criteria and these were of varying quality. This quality assessment is important to place the current evidence into the context of today's clinical practice. The predominant outcomes in these trials concentrated on postoperative complications and all the trials included either total or infectious complications (or both). A small number of trials reported on nutritional status measurements or dietary intake. The majority of the trials concentrated on malignant pathologies in well nourished patients.

The early trials investigated PN and, given current recommendations for the provision of nutritional support, would not necessarily be applicable to clinical practice today. In some trials, the volume of nutrition provided exceeded current guidelines and not all participants had a non-functioning GI tract or other relevant indication for PN according to current practice guidance National Institute 2006. In two out of three PN trials, participants receiving PN were malnourished and over half of participants were malnourished in the third trial. The administration of nutritional support favoured the intervention for the major complications, but favoured controls for infectious complications. This could possibly be attributed to over feeding and PN catheter infections which could have contributed to the number of participants experiencing an infectious event. Homogeneity between the trials evaluating $\mathrm{PN}$ was good.

There were only two trials which incorporated data on enteral nutrition in the preoperative period. The results on enteral nutrition were inconclusive. The trials had a high degree of homogeneity, albeit were assessed at a high risk or unclear risk of bias.

The results of the IE nutrition trials indicated a beneficial effect, but they required interpretation in view of exclusion criteria and patient selection. These trials could also be subject to temporal bias as there have been advances in surgical practice due to ERAS initiatives which affect surgical outcome and directly influence post-operative complication rates. The purpose of IE nutrition is to improve immune function and not to provide nutritional support. The trials did not state whether they had been undertaken in hospitals where ERAS protocols were in place. In addition, these results need to be considered in light of adverse reactions identified with arginine Suchner 2002 and omega 3 fatty acids Rice 2011 in critical care patient populations.

The trials on standard oral supplements which were carried out on predominantly well nourished participants, demonstrated no benefit.

\section{Overall completeness and applicability of evidence}

The evidence presented is applicable for the current management of GI surgical participants with regard to IE nutrition and standard supplements. The evaluation of PN is only of academic rel- evance and included for completeness due to temporal modifications in indications, assessment, prescribing and monitoring of intravenous nutritional support.

\section{Quality of the evidence}

The quality of the evidence is variable with some high quality trials included and others with a high risk of bias.

\section{Potential biases in the review process}

$S$ Burden was one of the reviews and is also an author on an included study.

\section{Agreements and disagreements with other studies or reviews}

A previous review incorporating IE nutrition in the preoperative period Cerantola 2011 concurs with the results presented in this review demonstrating that pre-operative IE nutrition reduced overall post-operative complications including non-infectious and infectious complications.

\section{AUTHORS' CONCLUSIONS}

\section{Implications for practice}

The results from pre-operative IE nutrition has favoured the intervention compare to control for non-infectious and infectious complications in predominantly well nourished surgical candidates and, in the absence of serious co-morbidities. Pre-operative IE showed inconclusive effects on length of stay. Immune-nutrition has not been evaluated in conjunction with ERAS programmes and has demonstrated no benefit in improving nutritional status in weight losing or malnourished surgical candidates in the preoperative period. It is note worthy that surgical candidates who are at the highest risk of incurring post-operative complications have been excluded from the majority of research on IE nutrition.

The data relating to pre-operative oral supplements and enteral nutrition are inconclusive. Pre-opperative PN had a positive effect on total complications but not on infectious complications in predominantly malnourished participants.

\section{Implications for research}

This review highlights the lack of research utilising standard oral supplementation for pre-operative nutritional support in malnourished patients under going GI surgery. The changing clinical environment has lead to the wide scale implementation of ERAS protocols for peri-operative management of surgical patients, thus future research would need to evaluate pre-operative regimens 
in conjunction with ERAS protocols. Immune-enhancing nutritional formulations require further evaluation with regard to the individual active components of the IE substrates. This will enable informed clinical decisions to be made with increased confidence in the use of IE nutrition in GI surgical candidates.

\section{ACKNOWLEDGEMENTS}

This proposal was supported by a Post Doctoral Fellowship Grant from Macmillan Cancer Support

\section{RE FER E N C E S}

\section{References to studies included in this review}

Braga 2002a \{published data only\}

Braga Marco, Gianotti Luca, Vignali Andrea, Carlo Valerio Di. Preoperative oral arginine and n-3 fatty acid supplementation improves the immunometabolic host response and outcome after colorectal resection for cancer. Surgery 2002;132(5):805-14.

Braga 2002b \{published data only\}

Braga Marco, Gianotti Luca, Nespoli Luca, Radaelli Giovanni, Di Carlo Valerio. Nutritional Approach in Malnourished Surgical Patients: A Prospective Randomized Study. Arch Surg 2002;137(2):174-80.

Burden 2011 \{published data only\} Burden S T, Hill J, Shaffer J L, Campbell M, Todd C. An unblinded randomised controlled trial of preoperative oral supplements in colorectal cancer patients. Journal of Human Nutrition \& Dietetics 2011;24(5):441-8.

Gianotti 2002 \{published data only\}

Gianotti Luca, Braga Marco, Nespoli Luca, Radaelli Giovanni, Beneduce Aldo, Di Carlo Valerio. A randomized controlled trial of preoperative oral supplementation with a specialized diet in patients with gastrointestinal cancer. Gastroenterology 2002;122(7):1763-70.

Gunerhan 2009 \{published data only\} Gunerhan Y Koksal N Sahin UY Uzun MA Ek ș ioglu-Demiralp E. Effect of preoperative immunonutrition and other nutrition models on cellular immune parameters. World J Gastroenterol. 2009;28(4):467-72.

MacFie 2000 \{published data only\}

MacFie, J, Woodcock, N. P, Palmer, M. D, et al.Oral dietary supplements in pre- and postoperative surgical patients: a prospective and randomized clinical trial. Nutrition 2000; 16:723-728.

McCarter 1998 \{published data only\}

McCarter M D, Gentilini O D, Gomez M E, Daly J M. Preoperative oral supplement with immunonutrients in cancer patients. Journal of Parenteral and Enteral Nutrition. 1998;22(4):206-11.
Muller 1982 \{published data only\}

Muller J M, Brenner U, Dienst C, Pichlmaier H.

Preoperative parenteral feeding in patients with gastrointestinal carcinoma. Lancet 1982;1(8263):68-71.

Okamoto 2009 \{published data only\} Okamoto Yoshiki, Okano Keiichi, Izuishi Kunihiko, Usuki Hisashi, Wakabayashi Hisao, Suzuki Yasuyuki. Attenuation of the systemic inflammatory response and infectious complications after gastrectomy with preoperative oral arginine and omega-3 fatty acids supplemented immunonutrition. World journal of surgery 2009;33(9): 1815-21.

Smedley 2004 \{published data only\} Smedley F, Bowling T, James M, Stokes E, Goodger C, O'Connor O, et al.Randomized clinical trial of the effects of preoperative and postoperative oral nutritional supplements on clinical course and cost of care. British Journal of Surgery 2004;91(8):983-90.

Smith 1988 \{published data only\}

Smith R C, Hartemink R. Improvement of nutritional measures during preoperative parenteral nutrition in patients selected by the prognostic nutritional index: a randomized controlled trial. Jpen: Journal of Parenteral \& Enteral Nutrition 1988;12(6):587-91.

Von Meyenfeldt 1992 \{published data only\} Von Meyenfeldt M F, Meijerink W J H J, Rouflart M M J, Builmaassen M T H J, Soeters P B. Perioperative nutritional support: a randomised clinical trial. Clinical Nutrition 1992;11(4):180-6.

Xu 2006 \{published data only\}

Xu J, Zhong Y, Jing D, Wu Z. Preoperative enteral immunonutrition improves postoperative outcome in patients with gastrointestinal cancer. Nutrition 2006;22: 713-721.

\section{References to studies excluded from this review}

Bozzetti 2001 \{published data only\}

Bozzetti F, Braga M, Gianotti L, Gavazzi C, Mariani

L. Postoperative enteral versus parenteral nutrition in 
malnourished patients with gastrointestinal cancer: a randomised multicentre trial. The Lancet 2001;358(9292): 1487-92.

Braga 1999 \{published data only\}

Braga Marco, Gianotti Luca, Radaelli Giovanni, Vignali Andrea, Mari Gilberto, Gentilini Oreste, et al.Perioperative Immunonutrition in Patients Undergoing Cancer Surgery: Results of a Randomized Double-blind Phase 3 Trial. Arch Surg 1999;134(4):428-33.

Finco 2007 \{published data only\}

* Finco C, Magnanini P, Sarzo G, Vecchiato M, Luongo B, Savastano $S$. Prospective randomized study on perioperative enteral immunonutrition in laparoscopic colorectal surgery. Surgical endoscopy 2007;21(7):175-9..

Gianotti 1999 \{published data only\}

Gianotti L, Braga M, Fortis C, Soldini L, Vignali A, Colombo S, et al.A prospective, randomized clinical trial on perioperative feeding with an arginine-, omega-3 fatty acid, and RNA-enriched enteral diet: Effect on host response and nutritional status. Journal of Parenteral and Enteral Nutrition 1999;23(6):356-9.

Giger 2007 \{published data only\} Giger U, Buchler M, Farhadi J, Berger D, Husler J, Schneider H, Krahenbuhl S, Krahenbuhl L. Preoperative immunonutrition suppresses perioperative inflammatory response in patients with major abdominal surgery-a randomized controlled pilot study.. Annals of Surgical Oncology 2007;14(10):2798-2806.

Heatley 1979 \{published data only\} Heatley RV, Williams RH, Lewis MH. Pre-operative intravenous feeding--a controlled trial. Postgraduate Medical Journal. Postgraduate Medical Journal 1979;55 (646):541-5..

Hendry 2008 \{published data only\} Hendry P O, Hausel J, Nygren J, Lassen K, Dejong $\mathrm{C} \mathrm{H}$ C, Ljungqvist $\mathrm{O}$, et al.Determinants of outcome after colorectal resection within an enhanced recovery programme. Colorectal Disease 2008;10:907-10.

Horie 2006 \{published data only\}

Horie H, Okada M, Kojima M, Nagai H. Favorable effects of preoperative enteral immunonutrition on a surgical site infection in patients with colorectal cancer without malnutrition. Surg Today 2006;36:1063-8.

Klek 2011 \{published data only\}

Klek Stanislaw, Sierzega Marek, Szybinski Piotr, Szczepanek Kinga, Scislo Lucyna, Walewska Elzbieta, et al.The immunomodulating enteral nutrition in malnourished surgical patients - a prospective, randomized, double-blind clinical trial. Clinical Nutrition 2011;30(3):282-8.

Lim 1981 \{published data only\}

Lim S T, Choa R G, Lam K H, Wong J, Ong G B. Total parenteral nutrition versus gastrostomy in the preoperative preparation of patients with carcinoma of the oesophagus. British Journal of Surgery 1981;68(2):69-72.
Lin 1997 \{published data only\}

Lin M T, Saito H, Fukushima R, Inaba T, Fukatsu K, Inoue $\mathrm{T}$, et al.Preoperative total parenteral nutrition influences postoperative systemic cytokine responses after colorectal surgery. Nutrition 1997;13(1):8-12.

Mueller 1982 \{published data only\}

Mueller J M, Brenner U, Dienst C, Pichlmaier

$\mathrm{H}$. Preoperative parenteral feeding in patients with gastrointestinal carcinoma. Lancet 1982;8263:68-71.

Ozkan 2002 \{published data only\}

Ozkan S, Gokben M, Ozsoy M, Acar V, Oncul O, Pocan S. Comparison of the effects of standart and immunonutrition on nutritional and immunological parameters undergoing major abdominal surgery. [Turkish]. Turk Anesteziyoloji ve Reanimasyon. 2002;30(10):473-9.

Rombeau 1982 \{published data only\}

Rombeau J L, Barot L R, Williamson C E, Mullen J L. Preoperative total parenteral nutrition and surgical outcome in patients with inflammatory bowel disease. American Journal of Surgery. 1982;143(1):139-43.

Ryan 2009 \{published data only\} Ryan Aoife M, Reynolds John V, Healy Laura, Byrne Miriam, Moore Jennifer, Brannelly Niamh, et al.Enteral nutrition enriched with eicosapentaenoic acid (EPA) preserves lean body mass following esophageal cancer surgery: results of a double-blinded randomized controlled trial. Annals of surgery 2009;249(3):355-63.

Sakurai 2007 \{published data only\}

Sakurai Yoichi, Masui Toshihiko, Yoshida Ikuo, Tonomura Shuhei, Shoji Mitsutaka, Nakamura Yasuko, et al.Randomized clinical trial of the effects of perioperative use of immune-enhancing enteral formula on metabolic and immunological status in patients undergoing esophagectomy. World journal of surgery 2007;31(11):21507; discussion 2158-9.

Senkal 1999 \{published data only\} Senkal M, Zumtobel V, Bauer K H, Marpe B, Wolfram G, Frei A, et al.Outcome and cost-effectiveness of perioperative enteral immunonutrition in patients undergoing elective upper gastrointestinal tract surgery: a prospective randomized study. Archives of Surgery 1999;134(12): 1309-16.

\section{Senkal 2005 \{published data only\}}

Senkal Metin, Haaker Rolf, Linseisen Jakob, Wolfram Gunther, Homann Heinz-Herbert, Stehle Peter. Preoperative oral supplementation with long-chain Omega3 fatty acids beneficially alters phospholipid fatty acid patterns in liver, gut mucosa, and tumor tissue. Jpen: Journal of Parenteral \& Enteral Nutrition 2005;29(4): 236-40.

Sodergren 2010 \{published data only\} Sodergren M H, Jethwa P, Kumar S, Duncan H D, Johns T, Pearce C B. Immunonutrition in patients undergoing major upper gastrointestinal surgery: a prospective doubleblind randomised controlled study. Scandinavian Journal of Surgery: SJS 2010;99(3):153-61. 
Takeuchi 2007 \{published data only\}

Takeuchi Hiroya, Ikeuchi Shunji, Kawaguchi Yoshiki, Kitagawa Yuko, Isobe Yoh, Kubochi Kiyoshi, et al.Clinical significance of perioperative immunonutrition for patients with esophageal cancer. World journal of surgery 2007;31 (11):2160-7.

\section{Additional references}

\section{Akbarshahi 2008}

Akbarshahi H, Andersson B, Norden M, Andersson R. Perioperative nutrition in elective gastrointestinal surgery-potential for improvement?. Digestive Surgery 2008;25(3): $165-74$.

Barbosa-Silva 2005

Barbosa-Silva MCG, Barros Aluisio JD. Bioelectric impedance and individual characteristics as prognostic factors for post-operative complications. Clinical Nutrition 2005;24(5):830-8.

\section{Beier-Holgersen 1996}

Beier-Holgersen R, Boesby S. Influence of postoperative enteral nutrition on postsurgical infections. Gut 1996;39

(6):833-5.

Braunschweig 2001

Braunschweig CL, Levy P, Sheean PM, Wang X. Enteral compared with parenteral nutrition: a meta-analysis. $\mathrm{Am} \mathrm{J}$ Clin Nutr 2001;74:534-42 2001;74:534-42.

\section{Cerantola 2011}

Cerantola Y, Hubner M, Grass F, N Demartines, M Schafer. Immunonutrition in gastrointestinal surgery. British Journal of Surgery 2011;98:37-48.

\section{Clark 2000}

Clark MA, Plank LD, Hill GL. Wound Healing Associated with Severe Surgical Illness. World Journal of Surgery 2000; 24(6):648-54.

\section{Copeland 1991}

Copeland GP Jones D Walters M. POSSUM: a scoring system for surgical audit. British Journal of Surgery 1991;78: 356-360.

\section{Correira 2003}

Correia MI, Waitzberg DL. The impact of malnutrition on morbidity, mortality, length of hospital stay and costs evaluated through a multivariate model analysis. Clinical Nutrition 2003;22(3):235-9.

Fettes 2002

Fettes SB, Davidson HI, Richardson RA, Pennington CR. Nutritional status of elective gastrointestinal surgery patients pre- and post-operatively. Clinical Nutrition 2002; 21(3):249-54.

Keele 1997

Keele AM, Bray MJ, Emery PW, Duncan HD, Silk DB. Two phase randomised controlled clinical trial of postoperative oral dietary supplements in surgical patients. Gut 1997;40(3):393-9.
Lassen 2009

Lassen K, Soop M, Nygren J, Cox PB, Hendry PO, Spies C, et al.Consensus Review of Optimal Perioperative Care in Colorectal Surgery: Enhanced Recovery After Surgery (ERAS) Group Recommendations. Arch Surg 2009;144 (10):961-9.

Leung 2009

Leung AM, Gibbons RL, Vu Huan N. Predictors of length of stay following colorectal resection for neoplasms in 183 Veterans Affairs patients. World Journal of Surgery 2009;33 (10):2183-8.

National Institute 2006

National Institute for Health and Clinical Excellencee. Clinical Guideline 32 Nutrition support in adults: oral nutrition support, enteral tube feeding and parenteral nutrition. www.nice.org.uk. National Institute for Clinical Excellence, 2006; Vol. G032.

\section{Rice 2011}

Rice TW, Wheeler AP, Thompson T, deBoisblanc PB, Steingrub J, Rock P. Enteral Omega-3 Fatty Acid, alfaLinolenic Acid, and Antioxidant Supplementation in Acute Lung Injury. Journal of American Medical Association 2011; 12:1574-1581.

\section{Russell 2008}

Russell CA, Elia M. Nutritional screening survey in the UK in 2008. BAPEN. BAPEN, 2008

\section{Schiesser 2008}

Schiesser M, Müller S, Kirchhoff P, Breitenstein S, Schäfer $\mathrm{M}$, Clavien PA. Assessment of a novel screening score for nutritional risk in predicting complications in gastrointestinal surgery. Clinical Nutrition 2008;27(4):565-70.

Schiesser 2009

Schiesser M, Kirchhoff P, Müller MK, Schäfer M, Clavien PA. The correlation of nutrition risk index, nutrition risk score, and bioimpedance analysis with postoperative complications in patients undergoing gastrointestinal surgery. Surgery 2009;145(5):519-26.

\section{Schwegler 2010}

Schwegler I, von Holzen A, Gutzwiller JP, Schlumpf R, Mühlebach S, Stanga Z. Nutritional risk is a clinical predictor of postoperative mortality and morbidity in surgery for colorectal cancer. British Journal of Surgery 2010; 97(1):92-7.

\section{Sorensen 2008}

Sorensen J, Kondrup J, Prokopowicz J, Schiesser M, Krähenbühl L, Meier R, et al.EuroOOPS: An international, multicentre study to implement nutritional risk screening and evaluate clinical outcome. Clinical Nutrition 2008;27 (3):340-9.

\section{Stratton 2003}

Stratton RJ, Green CJ, Elia M. Disease related malnutrition: an Evidence Based Approach to Treatment. Oxford: CABI, 2003. 
Suchner 2002

Suchner U Heyland D K Peter K. Immune-modulatory actions of arginine in the critically ill. British Journal of Nutrition 2002;87:S121-32.

Sungurtekin 2004

Sungurtekin H, Sungurtekin U, Balci C, Zencir M, Erdem

E. The Influence of Nutritional Status on Complications after Major Intraabdominal Surgery. J Am Coll Nutr 2004; 23(3):227-32.

* Indicates the major publication for the study 


\section{CHARACTERISTICS OF STUDIES}

\section{Characteristics of included studies [ordered by year of study]}

\section{MacFie 2000}

\begin{tabular}{ll}
\hline Methods & Randomised controlled trial \\
\hline Participants & $\begin{array}{l}100 \text { participants recruited requiring major GI surgery } \\
\text { Mean age range in groups 63-68 years } \\
\text { Male:female 46:54 }\end{array}$ \\
\hline Interventions & $\begin{array}{l}\text { Group 1-pre and postoperative supplements } \\
\text { Group 2-preoperative supplements } \\
\text { Group 3-postoperative supplements } \\
\text { Group 4-no supplements }\end{array}$ \\
\hline Outcomes & $\begin{array}{l}\text { weight change, total and septic complications, mortality, albumin,mid arm muscle cir- } \\
\text { cumference, hand grip strength and energy intake }\end{array}$ \\
\hline Notes & Outcome defined by Copeland 1991 \\
\hline
\end{tabular}

\section{Risk of bias}

\begin{tabular}{l|ll}
\hline Bias & Authors' judgement & Support for judgement \\
\hline $\begin{array}{l}\text { Random sequence generation (selection } \\
\text { bias) }\end{array}$ & Unclear risk & no information given \\
\hline $\begin{array}{l}\text { Allocation concealment (selection bias) } \\
\text { Blinding (performance bias and detection } \\
\text { bias) } \\
\text { All outcomes }\end{array}$ & Unclear risk risk & no information given \\
\hline $\begin{array}{l}\text { Incomplete outcome data (attrition bias) } \\
\text { All outcomes }\end{array}$ & Unclear risk & no blinding of oral supplements \\
\hline $\begin{array}{l}\text { Selective reporting (reporting bias) } \\
\text { Other bias }\end{array}$ & Low risk & $\begin{array}{l}12 \text { patients excluded from the analysis as they did not go } \\
\text { on to have surgery }\end{array}$ \\
\hline
\end{tabular}


Muller 1982

\begin{tabular}{|c|c|c|}
\hline Methods & \multicolumn{2}{|c|}{ Randomised controlled trial } \\
\hline Participants & \multicolumn{2}{|c|}{$\begin{array}{l}160 \text { patients approached, } 125 \text { included with carcinoma of the oesophagus, stomach, } \\
\text { colon, rectum or pancreas } \\
\text { Mean age range in groups } 58-59 \text { years } \\
\text { Male: female } 77: 48\end{array}$} \\
\hline Interventions & \multicolumn{2}{|c|}{$\begin{array}{l}\text { Intervention group - PN for } 10 \text { days } \\
\text { Control group - regular hospital diet }\end{array}$} \\
\hline Outcomes & \multicolumn{2}{|c|}{$\begin{array}{l}\text { Infectious and non infectious complications, mortality, serum protein levels, immuno- } \\
\text { logical status }\end{array}$} \\
\hline Notes & \multicolumn{2}{|c|}{$\begin{array}{l}\text { Patients considered malnourished if they had incurred a weight loss of more than } 5 \mathrm{~kg} \\
\text { in the previous } 3 \text { months prior to admission, serum albumin was below } 3.5 \mathrm{~g} / \mathrm{dl} \text { and the } \\
\text { response to five skin tests were negative }\end{array}$} \\
\hline \multicolumn{3}{|l|}{ Risk of bias } \\
\hline Bias & Authors' judgement & Support for judgement \\
\hline $\begin{array}{l}\text { Random sequence generation (selection } \\
\text { bias) }\end{array}$ & Unclear risk & No details given \\
\hline Allocation concealment (selection bias) & Unclear risk & No details given \\
\hline $\begin{array}{l}\text { Blinding (performance bias and detection } \\
\text { bias) } \\
\text { All outcomes }\end{array}$ & High risk & No blinding \\
\hline $\begin{array}{l}\text { Incomplete outcome data (attrition bias) } \\
\text { All outcomes }\end{array}$ & Unclear risk & $\begin{array}{l}\text { Not all patients included in the trial were in the analy- } \\
\text { sis, two patients did not have malignant disease and the } \\
\text { remaining patients did not go on to have surgery }\end{array}$ \\
\hline Selective reporting (reporting bias) & Unclear risk & All outcomes were reported \\
\hline Other bias & High risk & $\begin{array}{l}\text { Clinically lacks applicability as current recommendations } \\
\text { outline PN should only be administered in patients who } \\
\text { cannot meet their nutritional requirements via oral or en- } \\
\text { teral route. Amount of nutrition administered was quite } \\
\text { high compared to current practices }\end{array}$ \\
\hline
\end{tabular}




\begin{tabular}{|c|c|c|}
\hline Methods & \multicolumn{2}{|c|}{ Randomised controlled trial } \\
\hline Participants & \multicolumn{2}{|c|}{$\begin{array}{l}34 \text { Patients undergoing major GIl surgery including upper GI surgery and colorectal } \\
\text { surgery with a prognostic nutritional index score of }>30 \% \\
\text { Mean age range in groups } 67-68 \text { years } \\
\text { Male:female 27:7 }\end{array}$} \\
\hline Interventions & \multicolumn{2}{|c|}{10 Days preoperative $\mathrm{PN}$} \\
\hline Outcomes & \multicolumn{2}{|c|}{$\begin{array}{l}\text { Hand grip strength, infective and non-infective complications categorised as minor and } \\
\text { major. Outline of definitions for complications was pre defined in article }\end{array}$} \\
\hline \multicolumn{3}{|l|}{ Notes } \\
\hline \multicolumn{3}{|l|}{ Risk of bias } \\
\hline Bias & Authors' judgement & Support for judgement \\
\hline $\begin{array}{l}\text { Random sequence generation (selection } \\
\text { bias) }\end{array}$ & Unclear risk & $\begin{array}{l}\text { Randomly ordered cards in sealed envelopes opened after } \\
\text { the prognostic nutrition index was obtained. Does not } \\
\text { describe an audit trail for sealed envelopes }\end{array}$ \\
\hline Allocation concealment (selection bias) & Low risk & Sealed envelopes \\
\hline $\begin{array}{l}\text { Blinding (performance bias and detection } \\
\text { bias) } \\
\text { All outcomes }\end{array}$ & High risk & Not blinded \\
\hline $\begin{array}{l}\text { Incomplete outcome data (attrition bias) } \\
\text { All outcomes }\end{array}$ & Unclear risk & All patients included in the results \\
\hline Selective reporting (reporting bias) & Low risk & All outcomes reported \\
\hline Other bias & High risk & $\begin{array}{l}\text { Clinically lacks applicability as current recommendations } \\
\text { outline PN should only be administered in patients who } \\
\text { cannot meet their nutritional requirements via oral or } \\
\text { enteral routes. Amount of nutrition administered was } \\
\text { high compared to current practices }\end{array}$ \\
\hline
\end{tabular}

Von Meyenfeldt 1992

\begin{tabular}{ll}
\hline Methods & Randomised controlled trial \\
\hline Participants & $\begin{array}{l}200 \text { patients with histologically proven gastric or colorectal cancer requiring surgery less } \\
\text { than } 80 \text { years old and nutritionally depleted using albumin, total lymphocyte counts } \\
\text { and percentage ideal body weight. These were used to calculate nutritional index } \\
\text { Mean age range in groups 61-67 years } \\
\text { Male: females 126:74 }\end{array}$
\end{tabular}


Von Meyenfeldt 1992 (Continued)

\begin{tabular}{|c|c|c|}
\hline Interventions & \multicolumn{2}{|c|}{$\begin{array}{l}\text { Group } 1 \text { - preoperative parenteral nutrition }(n=51) \\
\text { Group } 2 \text { - preoperative enteral nutrition via nasogastric tube or by mouth }(n=50) \\
\text { Group } 3 \text { - no nutrition }(n=50) \\
\text { Group } 4 \text { - non depleted group not randomised }(n=49)\end{array}$} \\
\hline Outcomes & \multicolumn{2}{|c|}{ Complications defined in manuscript } \\
\hline Notes & \multicolumn{2}{|c|}{ Enterial nutrition used was Precitene or Isotein. } \\
\hline \multicolumn{3}{|l|}{ Risk of bias } \\
\hline Bias & Authors' judgement & Support for judgement \\
\hline $\begin{array}{l}\text { Random sequence generation (selection } \\
\text { bias) }\end{array}$ & Unclear risk & No information given \\
\hline Allocation concealment (selection bias) & Unclear risk & No information given \\
\hline $\begin{array}{l}\text { Blinding (performance bias and detection } \\
\text { bias) } \\
\text { All outcomes }\end{array}$ & High risk & Not blinded, however would be difficult to blind the trial \\
\hline $\begin{array}{l}\text { Incomplete outcome data (attrition bias) } \\
\text { All outcomes }\end{array}$ & Low risk & All patients randomised were included \\
\hline Selective reporting (reporting bias) & Low risk & All outcomes reported \\
\hline Other bias & Unclear risk & $\begin{array}{l}\text { Clinically lacks applicability as current recommendations } \\
\text { outline parenteral nutrition should only be administered } \\
\text { in patients who cannot meet their nutritional require- } \\
\text { ments via oral or enteral route. Amout of nutrition ad- } \\
\text { ministered was quite high compared to current practices }\end{array}$ \\
\hline
\end{tabular}

McCarter 1998

\begin{tabular}{ll}
\hline Methods & Randomised controlled trial \\
\hline Participants & $\begin{array}{l}38 \text { patients were approached and } 38 \text { included undergoing major surgery of the oesoph- } \\
\text { agus, stomach or pancreas for cancer were included } \\
\text { Mean age ranges from 62-66 years } \\
\text { Male:female 21:17 }\end{array}$ \\
\hline Interventions & $\begin{array}{l}\text { Group 1-Standard nutritional supplement } \\
\text { Group 2-Standard supplement with added arginine } \\
\text { Group 3-Standard supplement with added arginine and omega } 3 \text { fatty acids }\end{array}$ \\
\hline
\end{tabular}

Outcomes

Infectous and non infectious complications, length of stay, mortality 
McCarter 1998 (Continued)

\begin{tabular}{|c|c|c|}
\hline Notes & \multicolumn{2}{|c|}{$\begin{array}{l}\text { Excluded patients who had received chemotherapy or radiotherapy } \\
\text { No definitions used for complications }\end{array}$} \\
\hline \multicolumn{3}{|l|}{ Risk of bias } \\
\hline Bias & Authors' judgement & Support for judgement \\
\hline $\begin{array}{l}\text { Random sequence generation (selection } \\
\text { bias) }\end{array}$ & Unclear risk & No information given \\
\hline Allocation concealment (selection bias) & Unclear risk & No information given \\
\hline $\begin{array}{l}\text { Blinding (performance bias and detection } \\
\text { bias) } \\
\text { All outcomes }\end{array}$ & Low risk & Blinded \\
\hline $\begin{array}{l}\text { Incomplete outcome data (attrition bias) } \\
\text { All outcomes }\end{array}$ & High risk & 13 patients excluded from the analysis \\
\hline Selective reporting (reporting bias) & Low risk & All outcomes reported \\
\hline Other bias & Unclear risk & $\begin{array}{l}\text { Exclusion criteria - Evidence of active infection, renal } \\
\text { failure, hepatic failure, human immunodeficiency virus, } \\
\text { history of immunosuppressive therapy, uncontrolled di- } \\
\text { abetes and pregnancy }\end{array}$ \\
\hline
\end{tabular}

\section{Gianotti 2002}

\begin{tabular}{ll}
\hline Methods & Randomised controlled trial \\
\hline Participants & $\begin{array}{l}517 \text { patients assessed } 305 \text { patients with histologically proven neoplasm of the GI tract } \\
\text { and planned major elective surgery } \\
\text { Mean age range in groups 62-63 years } \\
\text { Male:female 166:139 }\end{array}$ \\
\hline
\end{tabular}

Interventions

Group 1-IEN 5 days preoperatively of a supplemented liquid diet $n=102$

Group 2-IEN 5 days preoperatively of a supplemented liquid diet and postoperatively jejunal feeding with the same formula before starting within 12 hours after surgery $n=$ 101

Group 3-No artificial nutrition before or after surgery $n=102$

Outcomes

Postoperative complications recorded up to 30 days by a member of surgical staff not directly involved in the study

Notes

IEN- IE nutrition with arginine and omega 3 fatty acids (Oral Impact Norvartis. Bern Switzerland) All patients with weight loss $\geq 10 \%$ of their previous weight in the previous 6 months

Excluded patients who had received neoadjuvant chemoradiotherapy 
Gianotti 2002 (Continued)

Post operative complications defined by Bozzetti 2001i 2001

\section{Risk of bias}

\begin{tabular}{|c|c|c|}
\hline Bias & Authors' judgement & Support for judgement \\
\hline $\begin{array}{l}\text { Random sequence generation (selection } \\
\text { bias) }\end{array}$ & Low risk & Individual random numbers \\
\hline Allocation concealment (selection bias) & Unclear risk & No details given on the process \\
\hline $\begin{array}{l}\text { Blinding (performance bias and detection } \\
\text { bias) } \\
\text { All outcomes }\end{array}$ & High risk & $\begin{array}{l}\text { No blinding. However, surgical staff not involved in the } \\
\text { trial applied the definitions for complications }\end{array}$ \\
\hline $\begin{array}{l}\text { Incomplete outcome data (attrition bias) } \\
\text { All outcomes }\end{array}$ & Low risk & All patients enrolled were included in the results \\
\hline Selective reporting (reporting bias) & Low risk & All outcomes reported \\
\hline Other bias & Unclear risk & $\begin{array}{l}\text { Extensive exclusion criteria limit generalizability of the } \\
\text { results. Exclusion criteria were weight loss } 10 \% \text { (with } \\
\text { respect to usual body weight) in the past } 6 \text { months, } \\
\text { age younger than } 18 \text { years, hepatic dysfunction (Child- } \\
\text { Pugh class B), respiratory dysfunction (arterial PaO2 } \\
70 \text { torr), renal dysfunction (serum creatinine level } 3 \\
\mathrm{mg} / \mathrm{dL} \text {, haemodialysis), cardiac dysfunction (New York } \\
\text { Heart Class 3), Karnofsky score } 60 \text {, pregnancy, ongo- } \\
\text { ing infections, and immune disorder (neoadjuvant ra- } \\
\text { diochemotherapy, circulating neutrophils } 2.0109 / \mathrm{L} \text { ) }\end{array}$ \\
\hline
\end{tabular}

Braga 2002b

\begin{tabular}{l|l}
\hline Methods & Randomised controlled trial \\
\hline Participants & 150 participants randomised undergoing elective surgery for GI malignance \\
\hline Interventions & $\begin{array}{l}\text { Goup 1- Standard enteral formula postoperatively } \\
\text { Group 2- IE formula } 7 \text { days preoperatively and standard enteral formula postoperatively } \\
\text { Group 3 - IE nutrition postoperatively }\end{array}$ \\
\hline Outcomes & postoperative complications and length of stay \\
\hline Notes & $\begin{array}{l}\text { Extensive exclusion criteria } \\
\text { Respiratory tract dysfunction (arterial PaO2 70 mm Hg) } \\
\text { Cardiac dysfunction (New York Heart Class 3, stroke history) } \\
\text { Karnofsky score 60 } \\
\text { Hepatic dysfunction (Child-Pugh score 2, portal hypertension) }\end{array}$ \\
\hline
\end{tabular}

Pre-operative Nutrition Support in Patients Undergoing Gastrointestinal Surgery. (Review) 
Ongoing infection

Renal dysfunction (serum creatinine level $3 \mathrm{mg} / \mathrm{dL}$

[265 mol/L], haemodialysis)

Immune disorder (neoadjuvant radiochemotherapy, neutrophil level

2000/IL, hypoimmunoglobulinemia)

Pregnancy

Age 18 Y

oral impact (Novartis Consumer Health, Bern, Switzerland)

Definitions for complications given in the paper

\section{Risk of bias}

\begin{tabular}{l|ll}
\hline Bias & Authors' judgement & Support for judgement \\
\hline $\begin{array}{l}\text { Random sequence generation (selection } \\
\text { bias) }\end{array}$ & Low risk & computer generated \\
\hline $\begin{array}{l}\text { Allocation concealment (selection bias) } \\
\text { Blinding (performance bias and detection } \\
\text { bias) } \\
\text { All outcomes }\end{array}$ & Unclear risk risk & Not detailed in method \\
\hline $\begin{array}{l}\text { Incomplete outcome data (attrition bias) } \\
\text { All outcomes }\end{array}$ & Low risk & Not blinded \\
\hline $\begin{array}{l}\text { Selective reporting (reporting bias) } \\
\text { Other bias }\end{array}$ & Low risk & Intention to treat analysis \\
\hline
\end{tabular}

Braga 2002a

Methods

Participants
Randomised controlled studies

233 patients were approached of whom 200 patients were included with colorectal neoplasm

Histologically proven colorectal cancer who were candidates for elective curative surgery Male:females 118:82

Mean age range in groups was 60.5-63 years

Interventions
Group 1- n=50, 1 litre of IEN 5 days before surgery and continued after surgery for by jejunal feeding

Group 2- n=50, 1 litre of IEN orally before surgery of IEN

Group 3-n=50, 1 litre of isonitrogenous and isoenergetic diet pre-operatively

Group 4- $n=50$, conventional diet did not receive any artificial diet before or after surgery 
Braga 2002a (Continued)

\begin{tabular}{|c|c|c|}
\hline Outcomes & \multicolumn{2}{|c|}{$\begin{array}{l}\text { Infectious complications, non infectious complications, anastomotic leak, antibiotic } \\
\text { therapy and length of stay. Patients followed up for complications for } 30 \text { days after } \\
\text { surgery }\end{array}$} \\
\hline Notes & \multicolumn{2}{|c|}{$\begin{array}{l}\text { IEN-immune enhancing nutrition with arginine and omega } 3 \text { fatty acids (Oral Impact } \\
\text { Norvartis. Bern Switzerland) } \\
10 \% \text { of participants had a weight loss }>10 \% \text { in the previous } 6 \text { months } \\
\text { Outcomes were defined Bozzetti } 20012001 \text { and were recorded by a member of surgical } \\
\text { staff independent from the study }\end{array}$} \\
\hline \multicolumn{3}{|l|}{ Risk of bias } \\
\hline Bias & Authors' judgement & Support for judgement \\
\hline $\begin{array}{l}\text { Random sequence generation (selection } \\
\text { bias) }\end{array}$ & Low risk & Randomisation was by a computer generated list. \\
\hline Allocation concealment (selection bias) & Unclear risk & $\begin{array}{l}\text { No mention of concealment of randomisation se- } \\
\text { quencing }\end{array}$ \\
\hline $\begin{array}{l}\text { Blinding (performance bias and detection } \\
\text { bias) } \\
\text { All outcomes }\end{array}$ & Unclear risk & $\begin{array}{l}\text { Interventions were blinded where it was possible to } \\
\text { do. }\end{array}$ \\
\hline $\begin{array}{l}\text { Incomplete outcome data (attrition bias) } \\
\text { All outcomes }\end{array}$ & Low risk & $\begin{array}{l}\text { All patients included in the study were included in the } \\
\text { intention to treat analysis }\end{array}$ \\
\hline Selective reporting (reporting bias) & Low risk & All outcomes measured were reported in the results. \\
\hline Other bias & Low risk & well conducted study \\
\hline
\end{tabular}

Smedley 2004

\begin{tabular}{l|l}
\hline Methods & Randomised controlled trial \\
\hline Participants & $\begin{array}{l}532 \text { were approached of whom } 179 \text { patients undergoing lower GI surgery were included } \\
\text { Mean age range in groups 55-63 years } \\
\text { Male:females 100:79 }\end{array}$ \\
\hline Interventions & $\begin{array}{l}\text { Group 1- Supplements were given preoperatively for a minimum of } 7 \text { days } \\
\text { Group 2- Supplements given pre and postoperatively up to } 4 \text { weeks after discharge from } \\
\text { hospital } \\
\text { Group 3-Supplements given postoperatively up to } 4 \text { weeks after discharge from hospital } \\
\text { Group 4- No artificial nutrition administered }\end{array}$ \\
\hline
\end{tabular}

Outcomes

Major and minor complications using definitions by Buzby 1988. Anthropometric measurements, nutritional intake, quality of life, length of stay, health service costs 
Smedley 2004 (Continued)

\begin{tabular}{|c|c|c|}
\hline Notes & \multicolumn{2}{|c|}{$\begin{array}{l}\text { Encouraged to drink supplements ad libitum } \\
\text { Supplement was Fortisip (Nutricia, Wageningen, The Netherlands) }\end{array}$} \\
\hline \multicolumn{3}{|l|}{ Risk of bias } \\
\hline Bias & Authors' judgement & Support for judgement \\
\hline $\begin{array}{l}\text { Random sequence generation (selection } \\
\text { bias) }\end{array}$ & Low risk & Sealed envelopes stratified according to nutritional status \\
\hline Allocation concealment (selection bias) & Low risk & Used sealed envelopes \\
\hline $\begin{array}{l}\text { Blinding (performance bias and detection } \\
\text { bias) } \\
\text { All outcomes }\end{array}$ & High risk & Unblinded \\
\hline $\begin{array}{l}\text { Incomplete outcome data (attrition bias) } \\
\text { All outcomes }\end{array}$ & High risk & $\begin{array}{l}27 \text { patients were withdrawn from the study this was at } \\
\text { the patients request, surgery cancelled, enteral or PN was } \\
\text { started }\end{array}$ \\
\hline Selective reporting (reporting bias) & Low risk & $\begin{array}{l}\text { No difference in quality of life mentioned. However no } \\
\text { data reported }\end{array}$ \\
\hline
\end{tabular}

Xu 2006

\begin{tabular}{|c|c|c|}
\hline Methods & \multicolumn{2}{|c|}{ Randomised controlled trial } \\
\hline Participants & \multicolumn{2}{|c|}{$\begin{array}{l}60 \text { participants colorectal and gastric carcinoma } \\
\text { Age range in groups } 57-60 \text { years } \\
\text { Male:female } 36: 24\end{array}$} \\
\hline Interventions & \multicolumn{2}{|c|}{ IE nutrition or standard enteral nutrition } \\
\hline Outcomes & \multicolumn{2}{|c|}{ complications infectious and total recorded by surgical staff not involved in the study } \\
\hline \multicolumn{3}{|l|}{ Notes } \\
\hline \multicolumn{3}{|l|}{ Risk of bias } \\
\hline Bias & Authors' judgement & Support for judgement \\
\hline $\begin{array}{l}\text { Random sequence generation (selection } \\
\text { bias) }\end{array}$ & Unclear risk & No information given \\
\hline Allocation concealment (selection bias) & Unclear risk & No information given \\
\hline
\end{tabular}


Xu 2006 (Continued)

\begin{tabular}{|c|c|c|}
\hline $\begin{array}{l}\text { Blinding (performance bias and detection } \\
\text { bias) } \\
\text { All outcomes }\end{array}$ & High risk & No information \\
\hline $\begin{array}{l}\text { Incomplete outcome data (attrition bias) } \\
\text { All outcomes }\end{array}$ & Low risk & All patients included in the analysis \\
\hline Selective reporting (reporting bias) & Unclear risk & All outcomes reported \\
\hline Other bias & Unclear risk & $\begin{array}{l}\text { Exclusion criteria included those with any of the follow- } \\
\text { ing conditions: pulmonary, cardiovascular, renal or hep- } \\
\text { atic disease; history of recent immunosuppressive ther- } \\
\text { apy (including preoperative radiochemotherapy) or im- } \\
\text { munological diseases; ongoing infection; emergency op- } \\
\text { eration; } \\
\text { or preoperative evidence of widespread metastatic dis- } \\
\text { ease. }\end{array}$ \\
\hline
\end{tabular}

Gunerhan 2009

\begin{tabular}{|c|c|c|}
\hline Methods & \multicolumn{2}{|c|}{ Randomised controlled trial } \\
\hline Participants & \multicolumn{2}{|c|}{$\begin{array}{l}56 \text { patients with GI tumours were included in the study } \\
\text { Mean age range in groups } 61-64.5 \text { years } \\
\text { Male:female 25:17 }\end{array}$} \\
\hline Interventions & \multicolumn{2}{|c|}{$\begin{array}{l}\text { Group } 1 \text { - IE nutrition } \mathrm{n}=16 \\
\text { Group } 2 \text { - Normal nutrition } \mathrm{n}=13 \\
\text { Group } 3 \text { - Standard enteral feed } \mathrm{n}=13\end{array}$} \\
\hline Outcomes & \multicolumn{2}{|c|}{ CRP, prealbumin, nitrogen balance, infection rates and duration of hospital stay } \\
\hline Notes & \multicolumn{2}{|c|}{ IE nutrition $=$ Impact Standard enteral feed $=$ Fresubin } \\
\hline \multicolumn{3}{|l|}{ Risk of bias } \\
\hline Bias & Authors' judgement & Support for judgement \\
\hline $\begin{array}{l}\text { Random sequence generation (selection } \\
\text { bias) }\end{array}$ & Unclear risk & No information given \\
\hline Allocation concealment (selection bias) & Unclear risk & No information given \\
\hline $\begin{array}{l}\text { Blinding (performance bias and detection } \\
\text { bias) } \\
\text { All outcomes }\end{array}$ & High risk & Not blinded \\
\hline
\end{tabular}


Gunerhan 2009 (Continued)

\begin{tabular}{l|l|l}
$\begin{array}{l}\text { Incomplete outcome data (attrition bias) } \\
\text { All outcomes }\end{array}$ & High risk & $\begin{array}{l}14 \text { patients excluded from the analysis due to GI bleed- } \\
\text { ing, emergency surgery to relieve an obstruction, and un- } \\
\text { controlled blood sugars }\end{array}$ \\
\hline Selective reporting (reporting bias) & Unclear risk & All outcomes reported \\
\hline Other bias & Unclear risk & $\begin{array}{l}\text { Extensive excluded criteria - Excluded patients with di- } \\
\text { abetes mellitus, renal and/or hepatic failure, and active } \\
\text { infection were excluded, as were the patients with a his- } \\
\text { tory of immunosuppressive drug use or clinical signs of } \\
\text { vitamin or trace element deficiency }\end{array}$ \\
\hline
\end{tabular}

Okamoto 2009

\begin{tabular}{ll}
\hline Methods & Randomised controlled trial \\
\hline Participants & $\begin{array}{l}60 \text { patients entered into the trial with gastric carcinoma } \\
\text { Male:female } 42: 18 \\
\text { Age range } 41-90 \text { years }\end{array}$ \\
\hline Interventions & $\begin{array}{l}\text { Intervention group was given } 750 \mathrm{mls} \text { of IEN for } 7 \text { days } \\
\text { Control received an isoenergetic standard formula for } 7 \text { days }\end{array}$ \\
\hline Outcomes & $\begin{array}{l}\text { Infectious and non infectious complications, immunological and nutritional measure- } \\
\text { ments. Length of hospital stay }\end{array}$ \\
\hline Notes & $\begin{array}{l}\text { IEN -IE nutrition with arginine and omega } 3 \text { fatty acids (Oral Impact, Ajinomoto } \\
\text { Pharma Co Ltd Japan) } \\
\text { Excluded abdominal radiotherapy and pre operative chemotherapy } \\
\text { Definition of complications outlined by authors }\end{array}$ \\
\hline
\end{tabular}

\section{Risk of bias}

\begin{tabular}{l|l|l}
\hline Bias & Authors' judgement & Support for judgement \\
\hline $\begin{array}{l}\text { Random sequence generation (selection } \\
\text { bias) }\end{array}$ & Unclear risk & block randomisation \\
\hline $\begin{array}{l}\text { Allocation concealment (selection bias) } \\
\text { Blinding (performance bias and detection } \\
\text { bias) } \\
\text { All outcomes }\end{array}$ & High risk & no information given \\
\hline $\begin{array}{l}\text { Incomplete outcome data (attrition bias) } \\
\text { All outcomes }\end{array}$ & Low risk & $\begin{array}{l}\text { Standard drink given as a control, no details given re- } \\
\text { garding the similarity in appearance or taste described }\end{array}$ \\
\hline
\end{tabular}

Pre-operative Nutrition Support in Patients Undergoing Gastrointestinal Surgery. (Review) 
Okamoto 2009 (Continued)

\begin{tabular}{|c|c|c|}
\hline Selective reporting (reporting bias) & Low risk & All outcomes reported \\
\hline Other bias & Unclear risk & $\begin{array}{l}\text { The exclusion criteria included those with any of the } \\
\text { following conditions: an unresectable neoplasm, previ- } \\
\text { ous abdominal radiotherapy, preoperative chemotherapy, } \\
\text { pulmonary, cardiovascular, renal or hepatic disease, his- } \\
\text { tory of recent immunosuppressive therapy (including } \\
\text { preoperative radiochemotherapy) or immunological dis- } \\
\text { eases, ongoing } \\
\text { infection, emergency operation, or preoperative evidence } \\
\text { of widespread metastatic disease, or stenotic lesions }\end{array}$ \\
\hline
\end{tabular}

Burden 2011

\begin{tabular}{l|l}
\hline Methods & Unblinded randomisation trial \\
\hline Participants & $\begin{array}{l}226 \text { were assessed for eligibility of whom } 125 \text { were enrolled } \\
\text { Subjective global assessment B and C indicating moderate to high risk of malnutrition } \\
45 \% \text { of participants } \\
\text { Mean age range in groups } 64.5-65.3 \text { years } \\
\text { Male:females } 72: 44\end{array}$ \\
\hline Interventions & $\begin{array}{l}\text { Intervention group received } 400 \mathrm{ml} \text { of oral supplement and dietary advice n=59 } \\
\text { control group received dietary advice n=66 }\end{array}$ \\
\hline Outcomes & $\begin{array}{l}\text { Infectious and non infectious complications, antibiotics, nutritional intake using 24 hour } \\
\text { unstructured dietary recall hospital anxiety and depression score, Karnofsky performance } \\
\text { index } \\
\text { Complications recorded up to } 3 \text { months post surgery. }\end{array}$ \\
\hline Notes & $\begin{array}{l}\text { Oral supplement was Fortisip Nutricia Ltd, Uk } \\
\text { Dietary advice was to increase energy and protein participants were given written infor- } \\
\text { mation } \\
\text { Two sets of published definitions were applied to postoperative complications Buzby et } \\
\text { al 1988 Ayliiffe et al 1993 }\end{array}$ \\
\hline
\end{tabular}

\section{Risk of bias}

\begin{tabular}{l|l|l}
\hline Bias & Authors' judgement & Support for judgement \\
\hline $\begin{array}{l}\text { Random sequence generation (selection } \\
\text { bias) }\end{array}$ & Low risk & Block randomisation \\
\hline Allocation concealment (selection bias) & Low risk & $\begin{array}{l}\text { Sequentially numbered brown opaque envelopes were } \\
\text { used }\end{array}$
\end{tabular}




\section{Burden 2011 (Continued)}

\begin{tabular}{|c|c|c|}
\hline $\begin{array}{l}\text { Blinding (performance bias and detection } \\
\text { bias) } \\
\text { All outcomes }\end{array}$ & High risk & No blinding was undertaken \\
\hline $\begin{array}{l}\text { Incomplete outcome data (attrition bias) } \\
\text { All outcomes }\end{array}$ & High risk & $\begin{array}{l}\text { There were patients who did not go on to have surgery } \\
\text { and these were not included in the analysis }\end{array}$ \\
\hline Selective reporting (reporting bias) & Low risk & All outcomes were reported \\
\hline Other bias & Unclear risk & $\begin{array}{l}\text { Imbalance at baseline more weight losing patients in } \\
\text { intervention group. However, did not effect outcome } \\
\text { on adjusted analysis }\end{array}$ \\
\hline
\end{tabular}

Characteristics of excluded studies [ordered by study ID]

\begin{tabular}{|c|c|}
\hline Study & Reason for exclusion \\
\hline Bozzetti 2001 & Post-operative administration of feed. \\
\hline Braga 1999 & Peri-operative administration of feed. \\
\hline Finco 2007 & Perio-perative comparator study. \\
\hline Gianotti 1999 & Does not report outcomes specified in review protocol. \\
\hline Giger 2007 & Pre-operative nutrition administered with postoperative nutritional support \\
\hline Heatley 1979 & Quasi randomised according to odd and even year of birth. \\
\hline Hendry 2008 & Not randomly allocated. \\
\hline Horie 2006 & Sequentially enrolled not randomised. \\
\hline Klek 2011 & Peri-opertive comparator study. \\
\hline Lim 1981 & Peri-operative data only. \\
\hline Lin 1997 & Did not include outcomes specified in the protocol. \\
\hline Mueller 1982 & Did not include a lipid source in the peripheral parenteral nutrition administered \\
\hline Ozkan 2002 & $\begin{array}{l}\text { Peri-operative administration of feed comparing pre and post-operative administration no data on pre-operative } \\
\text { administration only }\end{array}$ \\
\hline
\end{tabular}


(Continued)

Rombeau 1982 Not randomised

Ryan 2009 Peri-operative administration of feed comparing pre and post-operative administration no data on pre-operative administration only

Sakurai 2007 Peri-operative administration of feed comparing pre and post-operative administration no data on pre-operative administration only

Senkal 1999 Peri-operative administration of feed comparing pre and post-operative administration no data on pre-operative administration only

Senkal 2005 Did not include outcomes specified in the protocol.

Sodergren 2010 Post-operative feeding only.

Takeuchi 2007 Peri-operative administration of feed comparing pre and post-operative administration no data on pre-operative administration only 
DATA AND ANALYSES

Comparison 1. All immune enhancing nutrition trials compared to no nutrition or standard nutrition

\begin{tabular}{lccll} 
Outcome or subgroup title & $\begin{array}{c}\text { No. of } \\
\text { studies }\end{array}$ & $\begin{array}{c}\text { No. of } \\
\text { participants }\end{array}$ & Statistical method & Effect size \\
\hline 1 Total complications & 6 & 548 & Risk Ratio (M-H, Fixed, 95\% CI) & $0.67[0.53,0.84]$ \\
2 Infectious complications & 5 & 488 & Risk Ratio (M-H, Fixed, 95\% CI) & $0.51[0.35,0.73]$ \\
3 length of stay & 6 & 549 & Mean Difference (IV, Fixed, 95\% CI) & $-0.97[-1.64,-0.30]$ \\
\hline
\end{tabular}

Comparison 2. Preoperative immune enhancing nutrition compared to standard nutrition

\begin{tabular}{lccll} 
Outcome or subgroup title & $\begin{array}{c}\text { No. of } \\
\text { studies }\end{array}$ & $\begin{array}{c}\text { No. of } \\
\text { participants }\end{array}$ & Statistical method & Effect size \\
\hline 1 Total complications & 5 & 344 & Risk Ratio (M-H, Fixed, 95\% CI) & $0.61[0.44,0.84]$ \\
2 Infectious complications & 4 & 285 & Risk Ratio (M-H, Fixed, 95\% CI) & $0.51[0.31,0.84]$ \\
3 Length of stay & 4 & 285 & Mean Difference (IV, Fixed, 95\% CI) & $-1.01[-1.89,-0.14]$ \\
\hline
\end{tabular}

Comparison 3. Preoperative immune enhancing nutrition compared to no nutrition

\begin{tabular}{lccll} 
Outcome or subgroup title & $\begin{array}{c}\text { No. of } \\
\text { studies }\end{array}$ & $\begin{array}{c}\text { No. of } \\
\text { participants }\end{array}$ & Statistical method & Effect size \\
\hline 1 Total complications & 2 & 304 & Risk Ratio (M-H, Fixed, 95\% CI) & $0.67[0.51,0.89]$ \\
2 Infectious complications & 2 & 304 & Risk Ratio (M-H, Fixed, 95\% CI) & $0.43[0.27,0.70]$ \\
3 Length of stay & 2 & 304 & Mean Difference (IV, Fixed, 95\% CI) & $-2.59[-3.66,-1.52]$ \\
\hline
\end{tabular}

Comparison 4. Preoperative standard oral nutrition compared to no nutrition

\begin{tabular}{lcclc} 
Outcome or subgroup title & $\begin{array}{c}\text { No. of } \\
\text { studies }\end{array}$ & $\begin{array}{c}\text { No. of } \\
\text { participants }\end{array}$ & Statistical method & Effect size \\
\hline 1 Total complications & 3 & 263 & Risk Ratio (M-H, Fixed, 95\% CI) & $1.06[0.82,1.36]$ \\
2 Infectious complications & 3 & 250 & Risk Ratio (M-H, Fixed, 95\% CI) & $1.09[0.83,1.42]$ \\
3 Length of stay & 2 & 206 & Mean Difference (IV, Fixed, 95\% CI) & $0.05[-2.65,2.74]$ \\
\hline
\end{tabular}




\begin{tabular}{lccll} 
Outcome or subgroup title & $\begin{array}{c}\text { No. of } \\
\text { studies }\end{array}$ & $\begin{array}{c}\text { No. of } \\
\text { participants }\end{array}$ & Statistical method & Effect size \\
\hline 1 Total complications & 2 & 120 & Risk Ratio (M-H, Fixed, 95\% CI) & $0.79[0.56,1.10]$ \\
2 Infectious complications & 2 & 120 & Risk Ratio (M-H, Fixed, 95\% CI) & $1.00[0.69,1.44]$ \\
\hline
\end{tabular}

Comparison 6. Preoperative parenteral nutrition compared to no nutrition

\begin{tabular}{lccll} 
Outcome or subgroup title & $\begin{array}{c}\text { No. of } \\
\text { studies }\end{array}$ & $\begin{array}{c}\text { No. of } \\
\text { participants }\end{array}$ & Statistical method & Effect size \\
\hline 1 Major complications & 3 & 260 & Risk Ratio (M-H, Fixed, 95\% CI) & $0.64[0.46,0.87]$ \\
2 Infectious complications & 2 & 226 & Risk Ratio (M-H, Fixed, 95\% CI) & $0.94[0.80,1.10]$ \\
\hline
\end{tabular}

\section{Analysis I.I. Comparison I All immune enhancing nutrition trials compared to no nutrition or standard nutrition, Outcome I Total complications.}

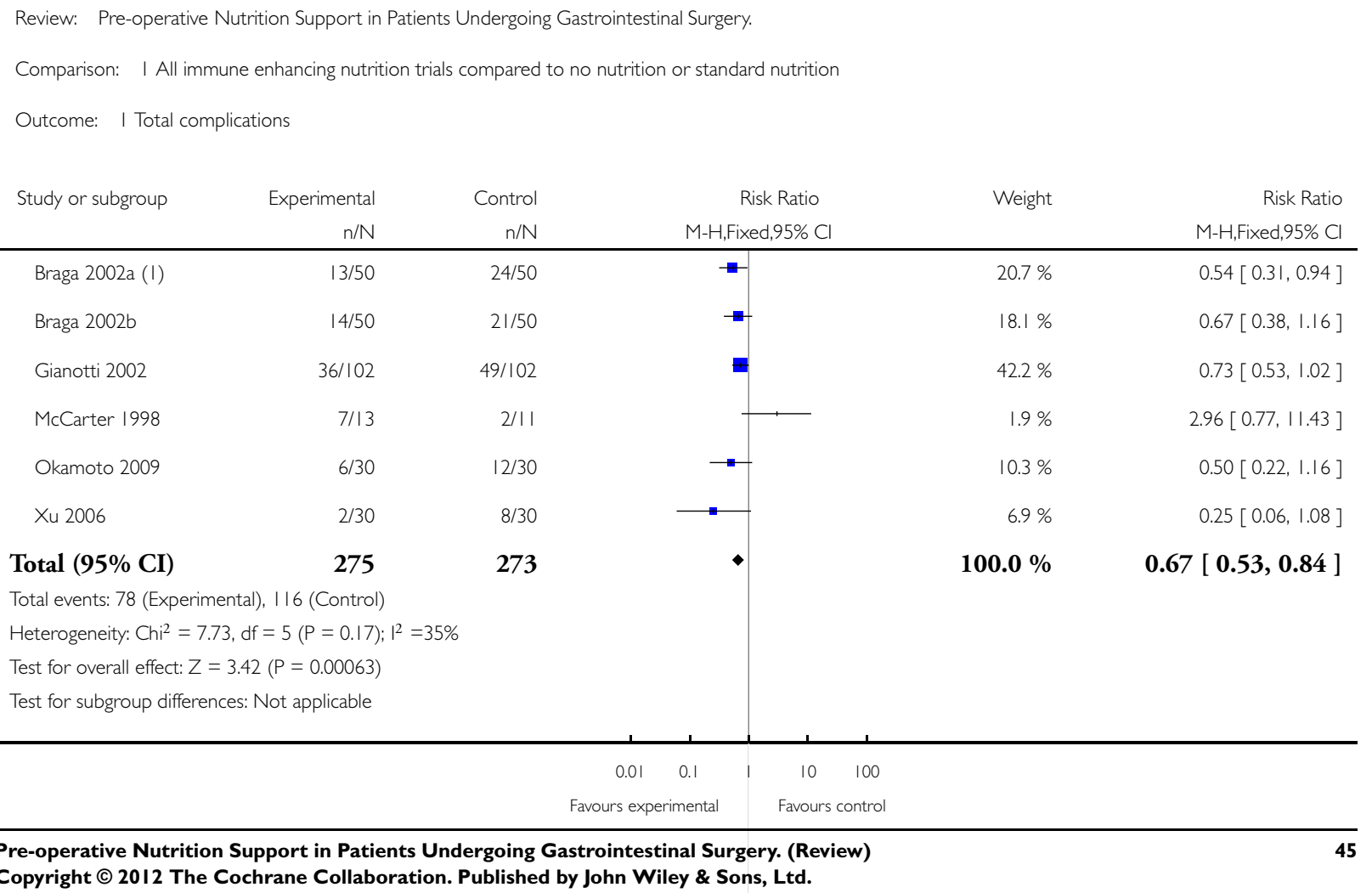


(I) Data comparing immune enhancing nutrition to no nutrition is used in the first instance.

\section{Analysis I.2. Comparison I All immune enhancing nutrition trials compared to no nutrition or standard nutrition, Outcome 2 Infectious complications.}

Review: Pre-operative Nutrition Support in Patients Undergoing Gastrointestinal Surgery.

Comparison: I All immune enhancing nutrition trials compared to no nutrition or standard nutrition

Outcome: 2 Infectious complications

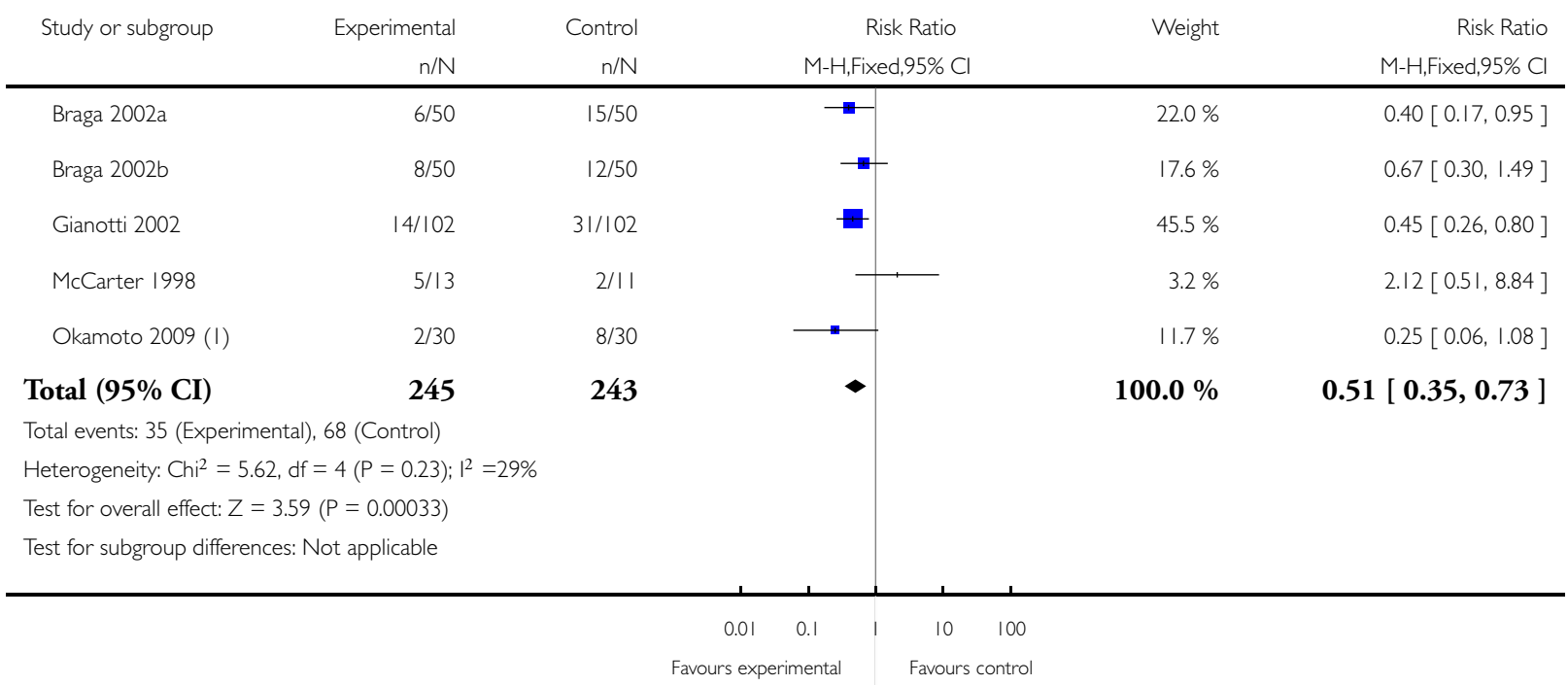

( I) Xu- not included as infections given as counts not a dichotomous variable 
Analysis I.3. Comparison I All immune enhancing nutrition trials compared to no nutrition or standard nutrition, Outcome 3 length of stay.

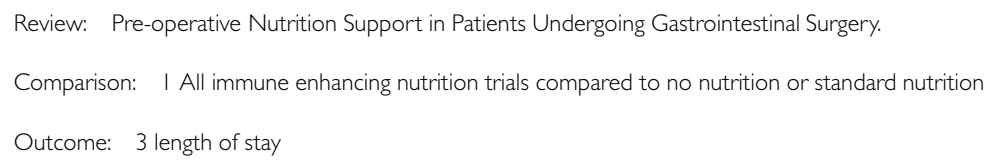

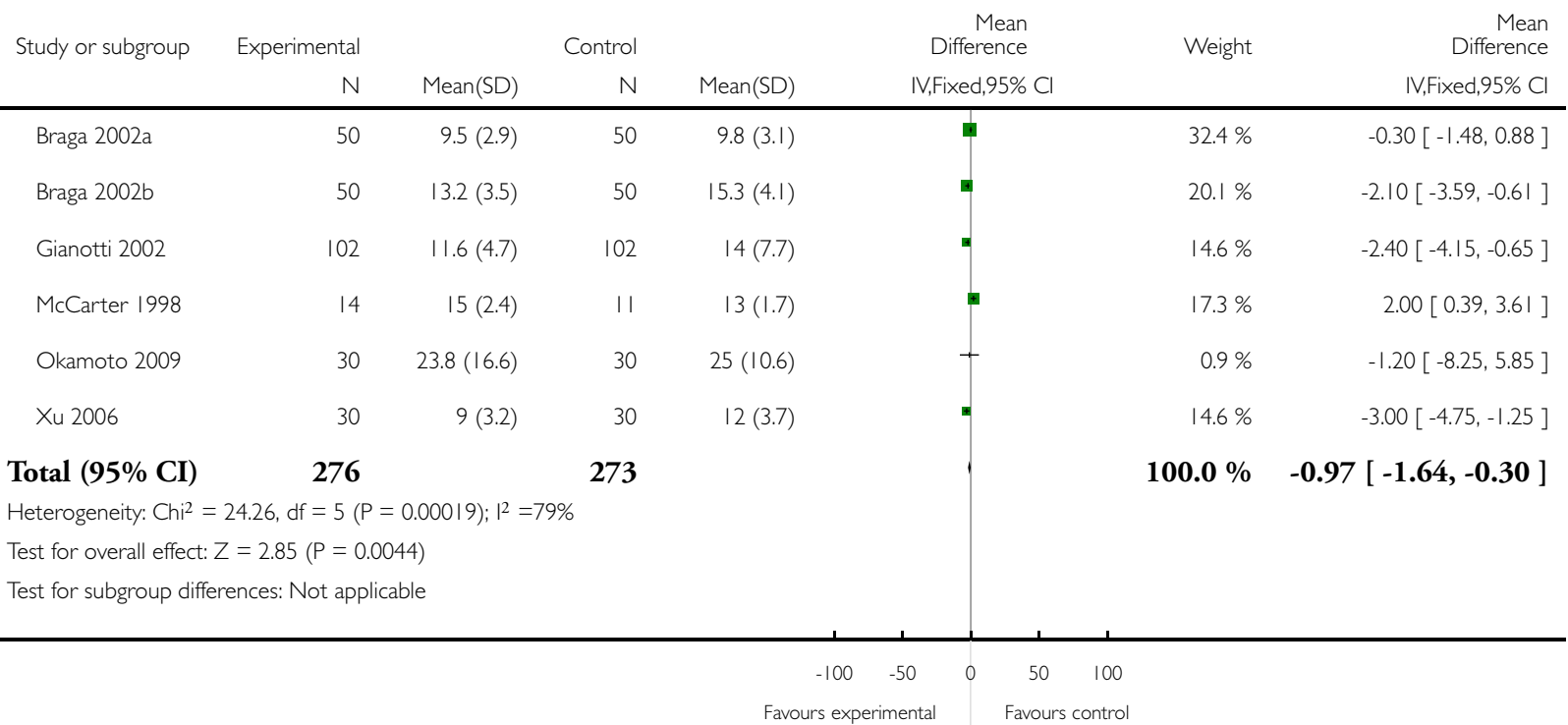




\section{Analysis 2.1. Comparison 2 Preoperative immune enhancing nutrition compared to standard nutrition,} Outcome I Total complications.

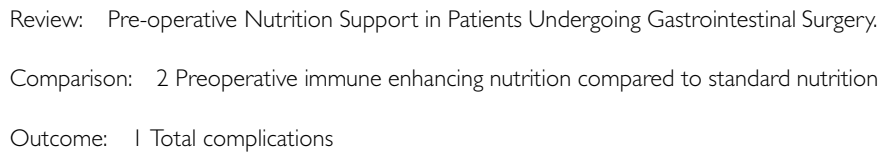

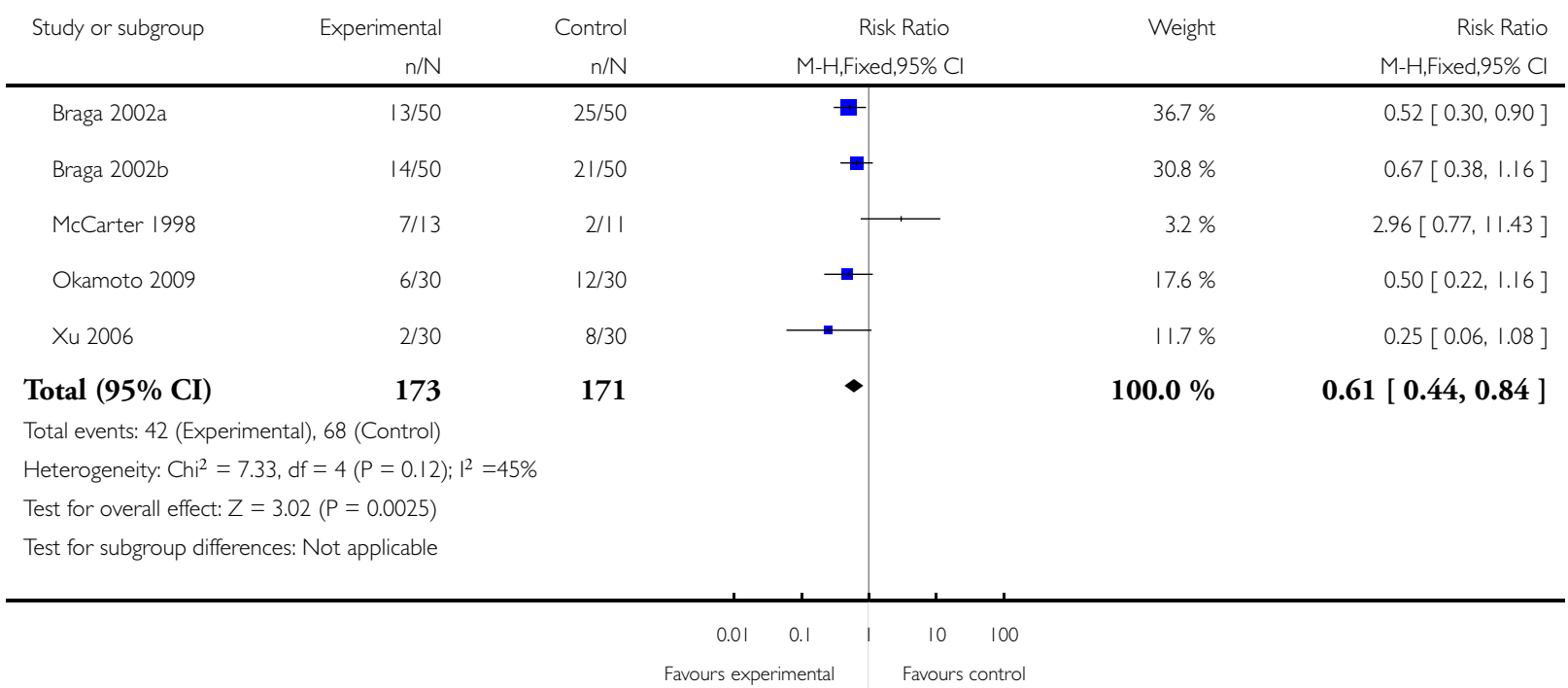




\section{Analysis 2.2. Comparison 2 Preoperative immune enhancing nutrition compared to standard nutrition,}

Outcome 2 Infectious complications.

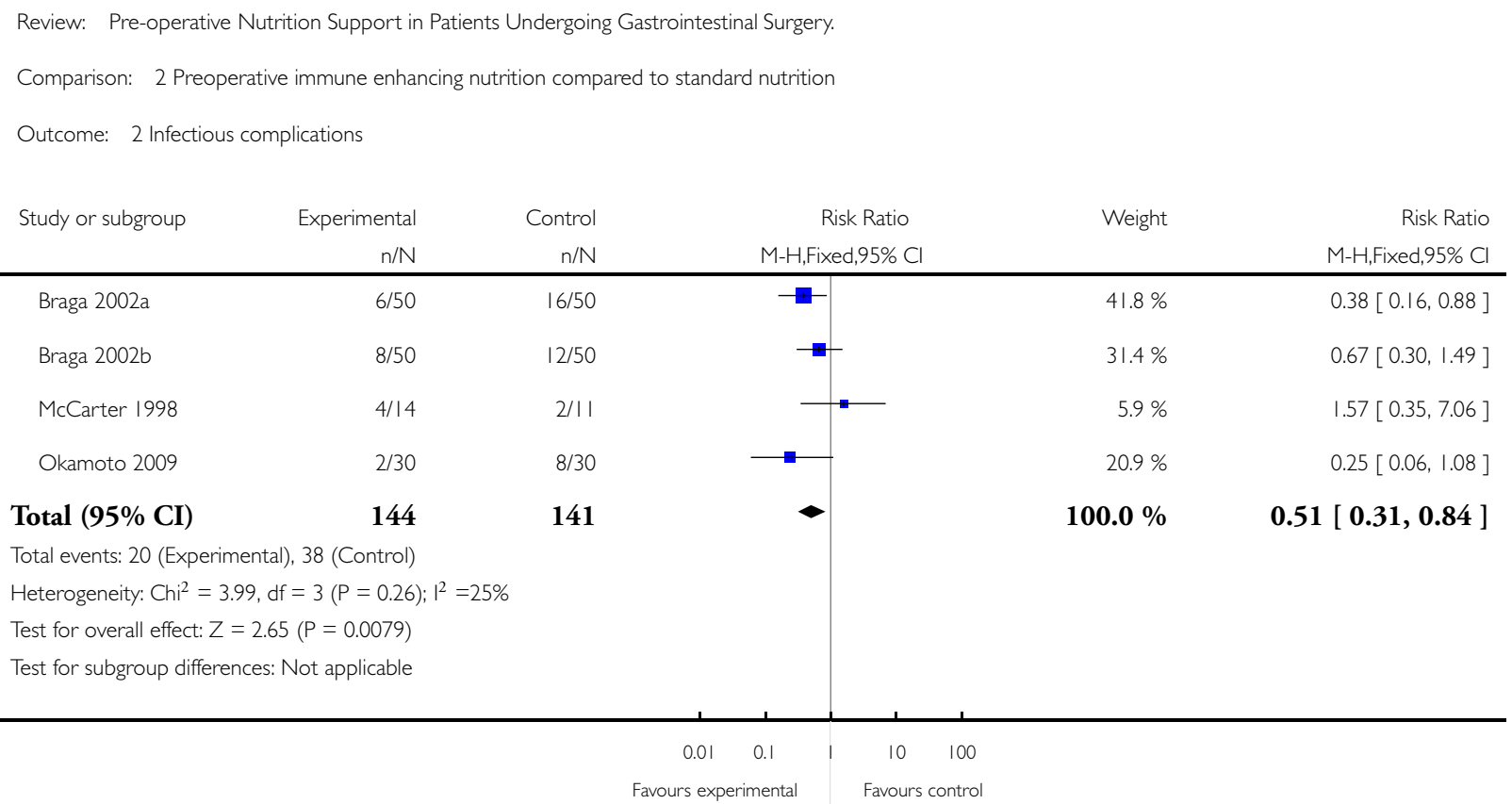




\section{Analysis 2.3. Comparison 2 Preoperative immune enhancing nutrition compared to standard nutrition,}

Outcome 3 Length of stay.

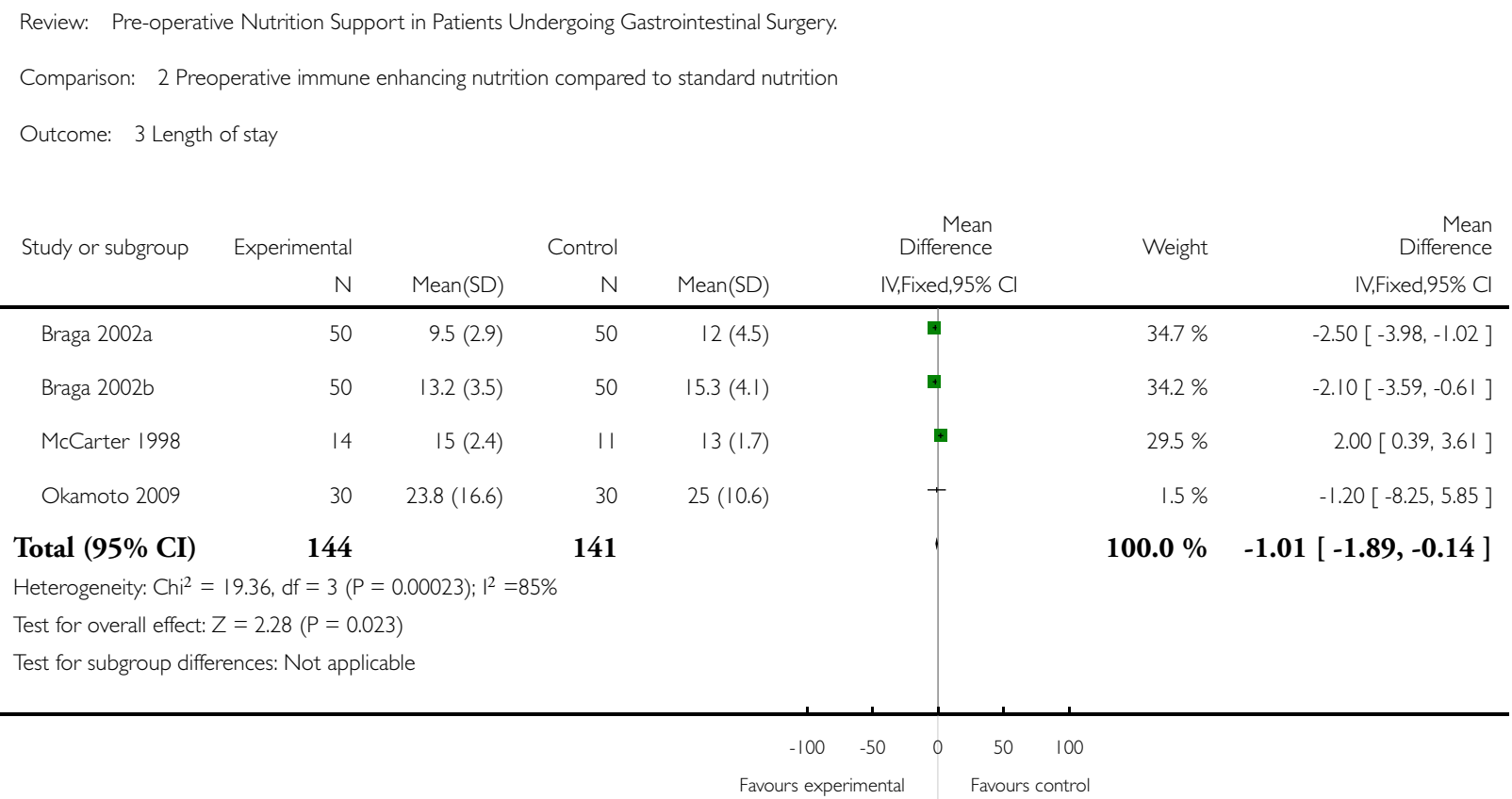


Analysis 3.I. Comparison 3 Preoperative immune enhancing nutrition compared to no nutrition, Outcome I Total complications.

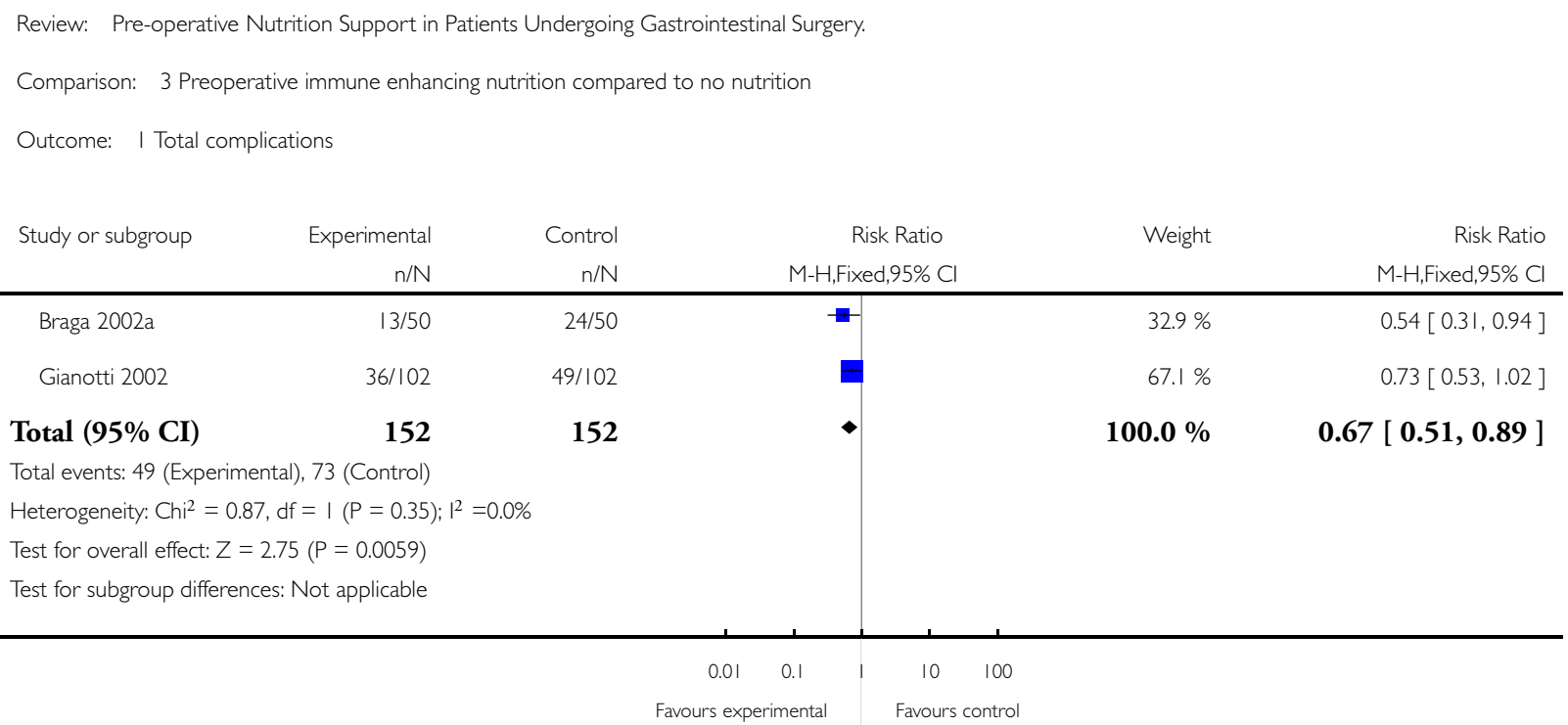

Analysis 3.2. Comparison 3 Preoperative immune enhancing nutrition compared to no nutrition, Outcome 2 Infectious complications.

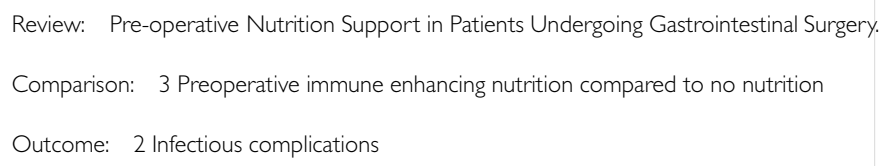

\begin{tabular}{|c|c|c|c|c|c|}
\hline Study or subgroup & Experimental & Control & Risk Ratio & Weight & Risk Ratio \\
\hline & $\mathrm{n} / \mathrm{N}$ & $\mathrm{n} / \mathrm{N}$ & M-H,Fixed,95\% Cl & & M-H,Fixed,95\% Cl \\
\hline Braga 2002a & $6 / 50$ & $15 / 50$ & - & $32.6 \%$ & $0.40[0.17,0.95]$ \\
\hline Gianotti 2002 & $14 / 102$ & $31 / 102$ & -7 & $67.4 \%$ & $0.45[0.26,0.80]$ \\
\hline
\end{tabular}

Total $(\mathbf{9 5 \%}$ CI)

Total events: 20 (Experimental), 46 (Control) Heterogeneity: $\mathrm{Chi}^{2}=0.05, \mathrm{df}=\mathrm{I}(\mathrm{P}=0.82) ; \mathrm{I}^{2}=0.0 \%$ Test for overall effect: $Z=3.44(P=0.00058)$

Test for subgroup differences: Not applicable 


\section{Analysis 3.3. Comparison 3 Preoperative immune enhancing nutrition compared to no nutrition, Outcome}

3 Length of stay.

Review: Pre-operative Nutrition Support in Patients Undergoing Gastrointestinal Surgery.

Comparison: 3 Preoperative immune enhancing nutrition compared to no nutrition

Outcome: 3 Length of stay

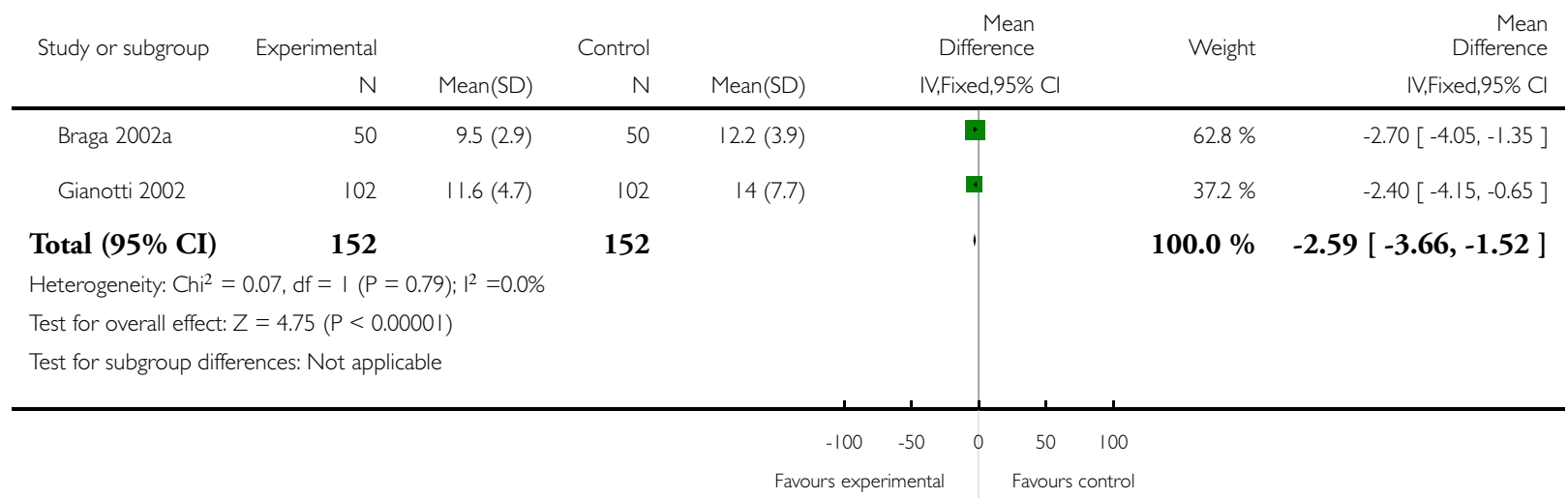


Analysis 4.I. Comparison 4 Preoperative standard oral nutrition compared to no nutrition, Outcome I Total complications.

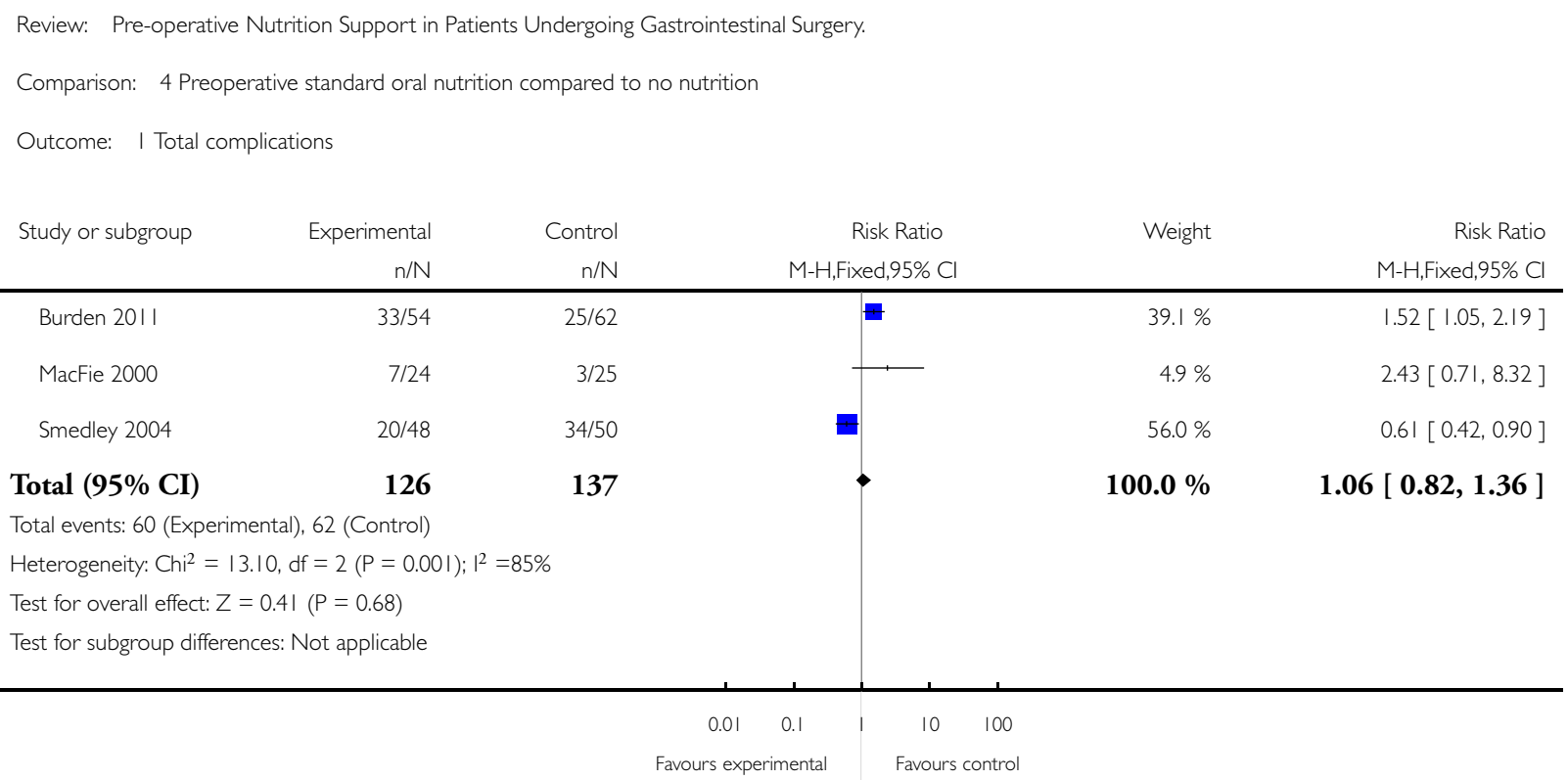


Analysis 4.2. Comparison 4 Preoperative standard oral nutrition compared to no nutrition, Outcome 2 Infectious complications.

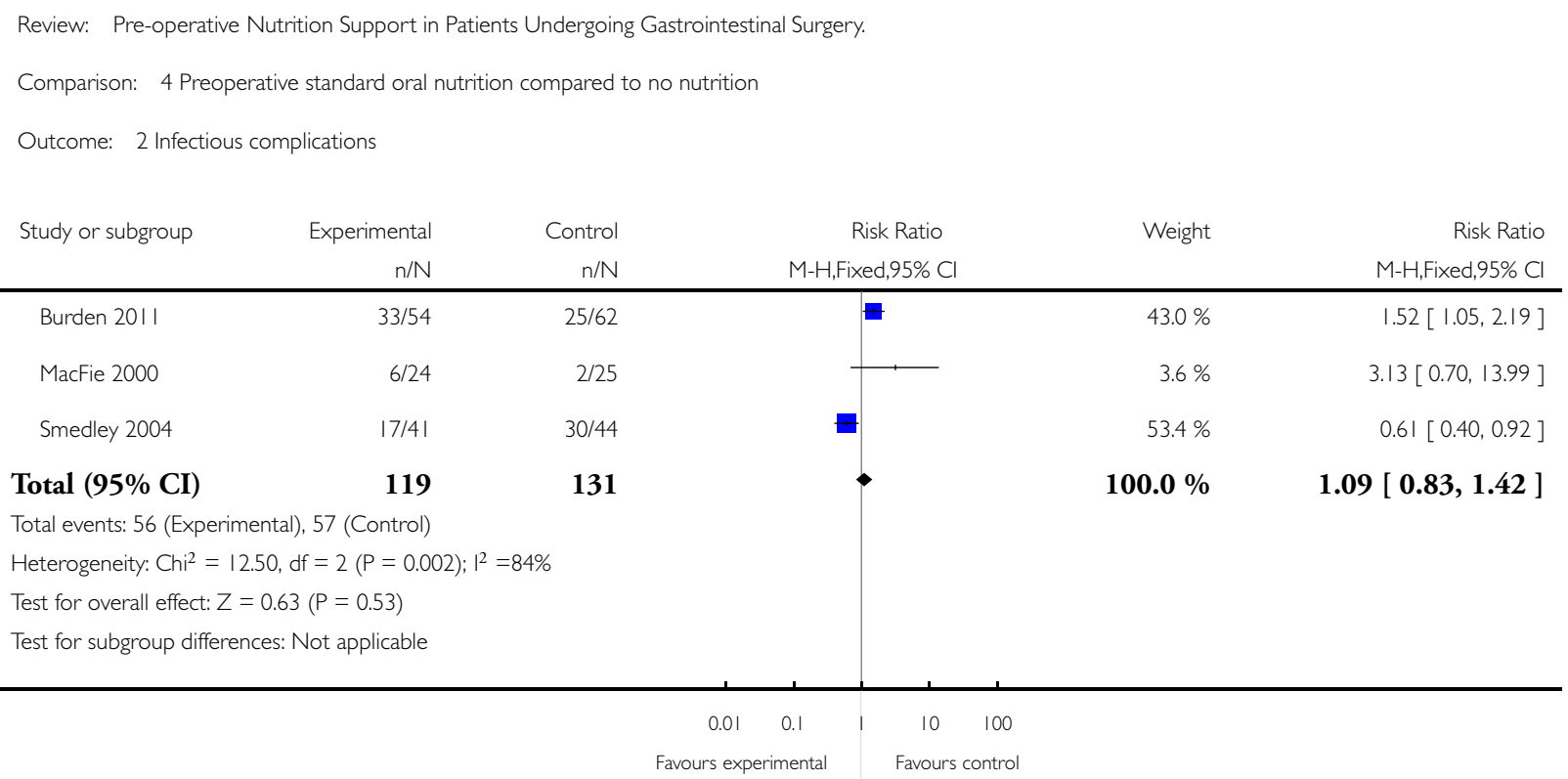


Analysis 4.3. Comparison 4 Preoperative standard oral nutrition compared to no nutrition, Outcome 3 Length of stay.

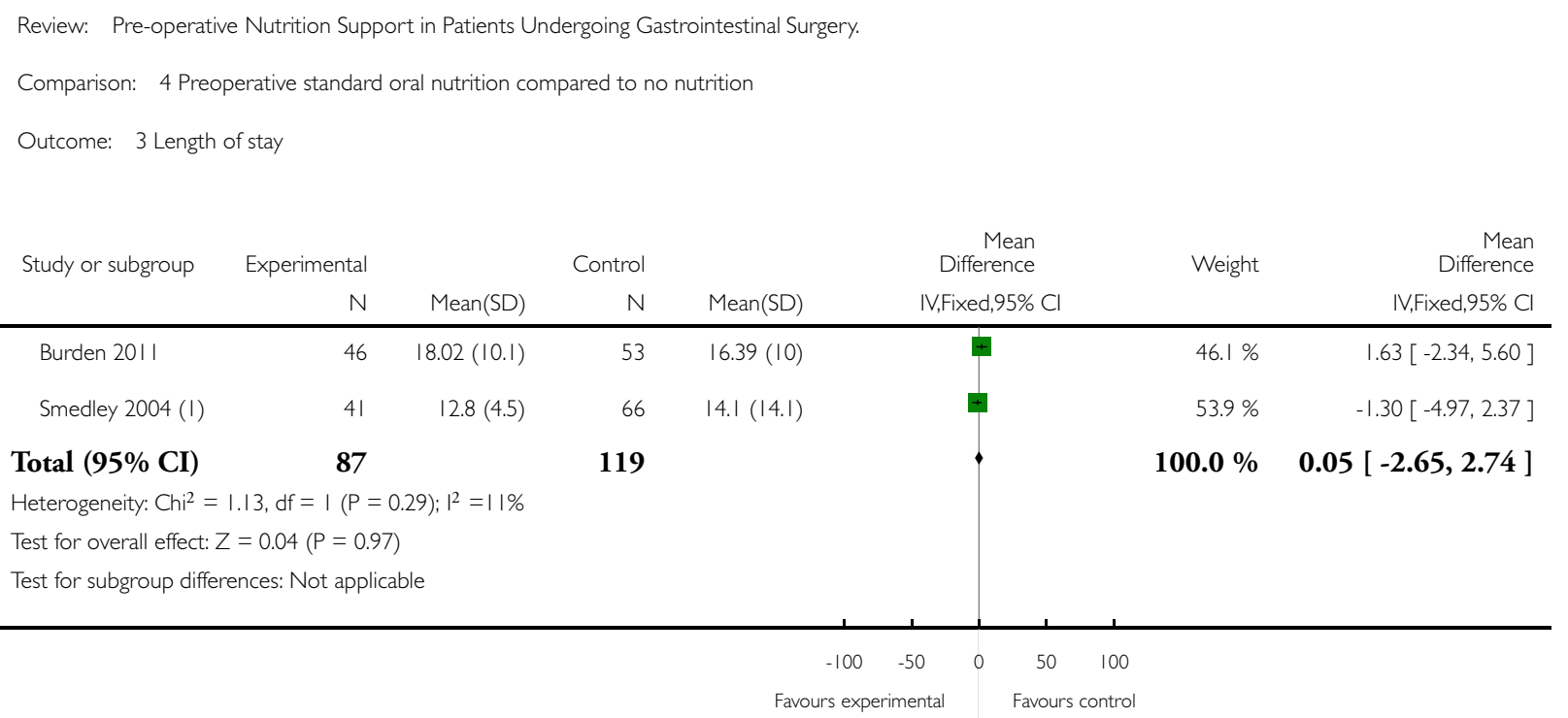

(I) Burden 201 I- unpublished data used

\section{Analysis 5.I. Comparison 5 Preoperative enteral nutrition compared to no nutrition, Outcome I Total complications.}

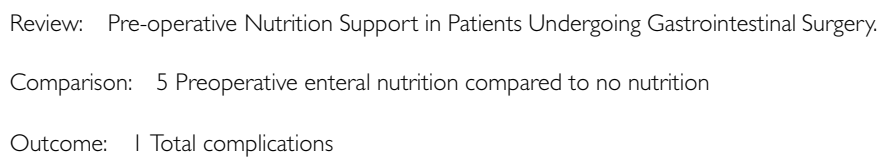

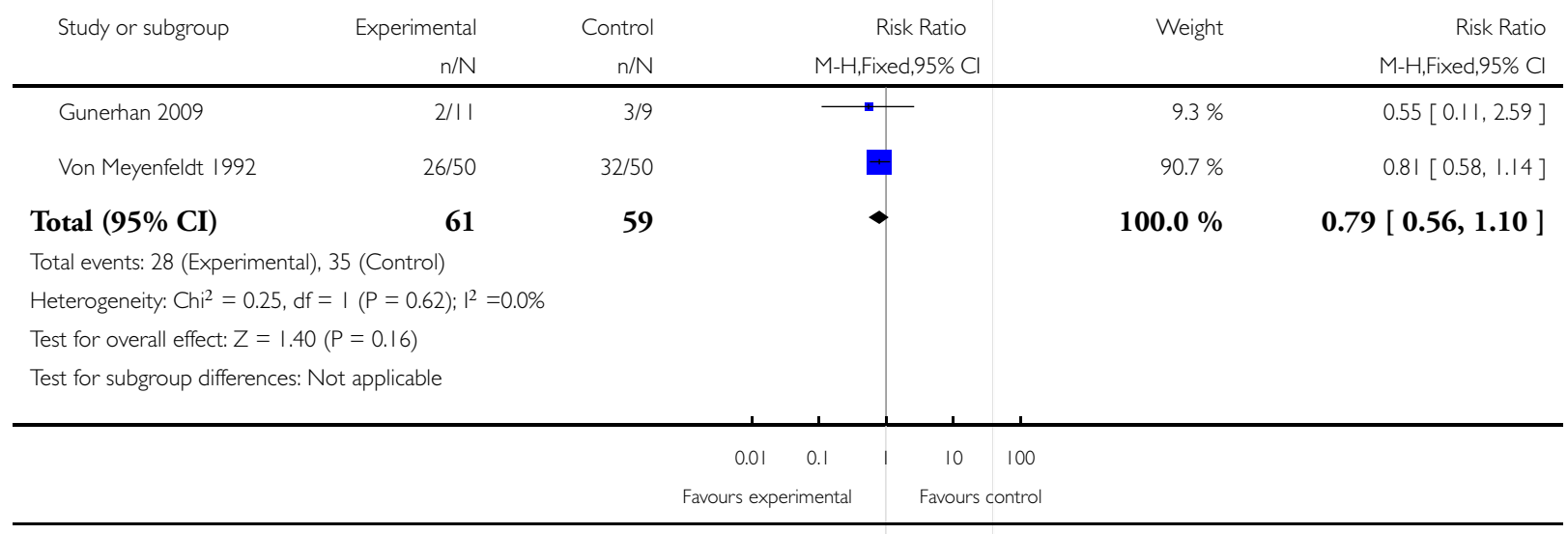




\section{Analysis 5.2. Comparison 5 Preoperative enteral nutrition compared to no nutrition, Outcome 2 Infectious}

complications.

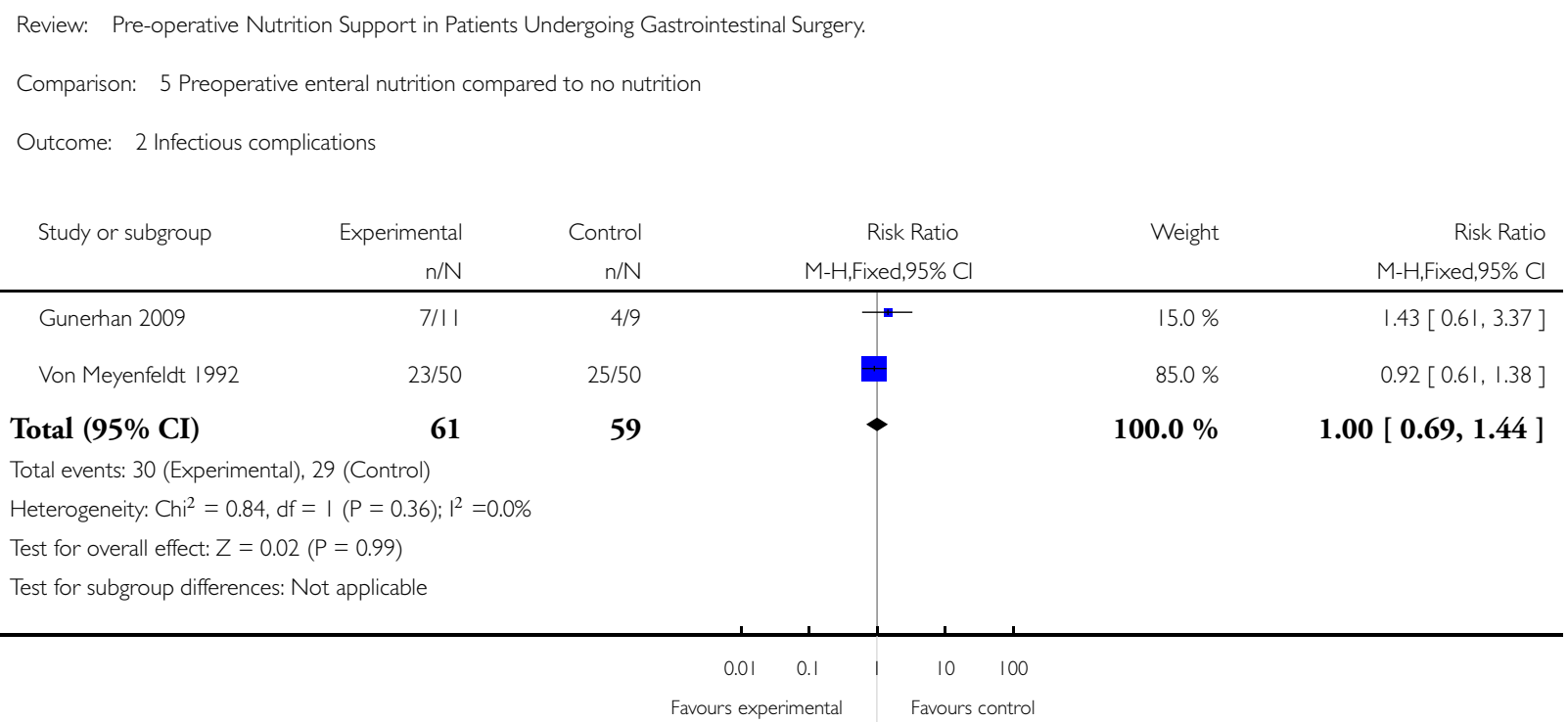


Analysis 6.I. Comparison 6 Preoperative parenteral nutrition compared to no nutrition, Outcome I Major complications.

\begin{tabular}{|c|c|c|c|c|c|}
\hline \multicolumn{6}{|c|}{ Comparison: 6 Preoperative parenteral nutrition compared to no nutrition } \\
\hline \multicolumn{6}{|c|}{ Outcome: I Major complications } \\
\hline \multirow[t]{2}{*}{ Study or subgroup } & Experimental & Control & Risk Ratio & Weight & Risk Ratio \\
\hline & $n / N$ & $\mathrm{n} / \mathrm{N}$ & M-H,Fixed,95\% Cl & & M-H,Fixed,95\% Cl \\
\hline Muller 1982 & $11 / 66$ & $19 / 59$ & 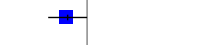 & $34.4 \%$ & $0.52[0.27,1.00]$ \\
\hline Smith 1988 & $3 / 17$ & $6 / 17$ & $\because-$ & $10.3 \%$ & $0.50[0.15,1.68]$ \\
\hline Von Meyenfeldt 1992 & $24 / 51$ & $32 / 50$ & 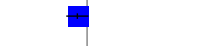 & $55.4 \%$ & $0.74[0.51,1.05]$ \\
\hline Total $(95 \% \mathrm{CI})$ & 134 & 126 & $\bullet$ & $100.0 \%$ & $0.64[0.46,0.87]$ \\
\hline \multicolumn{6}{|c|}{ Total events: 38 (Experimental), 57 (Control) } \\
\hline \multicolumn{6}{|c|}{ Heterogeneity: $\mathrm{Chi}^{2}=1.16, \mathrm{df}=2(\mathrm{P}=0.56) ; \mathrm{I}^{2}=0.0 \%$} \\
\hline \multicolumn{6}{|c|}{ Test for overall effect: $Z=2.82(P=0.0048)$} \\
\hline \multicolumn{6}{|c|}{ Test for subgroup differences: Not applicable } \\
\hline
\end{tabular}




\section{Analysis 6.2. Comparison 6 Preoperative parenteral nutrition compared to no nutrition, Outcome 2 Infectious complications.}

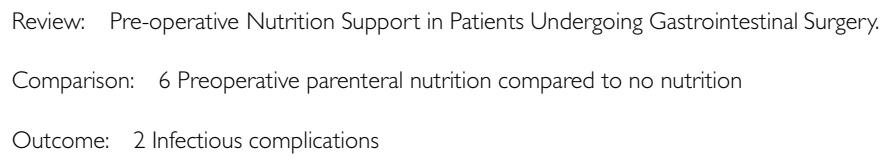

\begin{tabular}{|c|c|c|c|c|c|}
\hline \multirow[t]{2}{*}{ Study or subgroup } & Experimental & Control & Risk Ratio & \multirow[t]{2}{*}{ Weight } & \multirow{2}{*}{$\begin{array}{r}\text { Risk Ratio } \\
\text { M-H,Fixed,95\% Cl }\end{array}$} \\
\hline & $\mathrm{n} / \mathrm{N}$ & $\mathrm{n} / \mathrm{N}$ & M-H,Fixed,95\% Cl & & \\
\hline Muller 1982 & $45 / 66$ & $57 / 59$ & & $70.4 \%$ & $0.71[0.59,0.84]$ \\
\hline Von Meyenfeldt 1992 & $38 / 51$ & $25 / 50$ & : & $29.6 \%$ & $1.49[1.08,2.05]$ \\
\hline Total $(95 \%$ CI $)$ & 117 & 109 & 4 & $100.0 \%$ & $0.94[0.80,1.10]$ \\
\hline \multicolumn{6}{|c|}{ Total events: 83 (Experimental), 82 (Control) } \\
\hline \multicolumn{6}{|c|}{ Heterogeneity: $\mathrm{Chi}^{2}=18.56, \mathrm{df}=|(P=0.00002) ;|^{2}=95 \%$} \\
\hline \multicolumn{6}{|c|}{ Test for overall effect: $Z=0.80(P=0.43)$} \\
\hline Test for subgroup differen & t applicable & & & & \\
\hline
\end{tabular}

\section{ADDITIONAL TABLES}

Table 1. Characteristics of the trials included on preoperative feeding

\begin{tabular}{|c|c|c|c|c|}
\hline $\begin{array}{l}\text { Study } \\
\& \text { country }\end{array}$ & Site of surgery & Feed type and volume & Route and duration & undernourished \\
\hline $\begin{array}{l}\text { Muller } 1982 \\
\text { Germay }\end{array}$ & $\begin{array}{l}\text { oesophagus } \\
\text { stomach } \\
\text { colon } \\
\text { rectum } \\
\text { pancreas }\end{array}$ & $\begin{array}{l}1.5 \mathrm{~g} \text { amino acids } / \mathrm{kg} \\
11 \mathrm{~g} \text { glucose } / \mathrm{kg}\end{array}$ & $\begin{array}{l}10 \text { days } \\
\text { central venous catheter }\end{array}$ & $\begin{array}{l}62 \% \text { controls } \\
59 \% \text { active } \\
\text { (weight loss >5\% in } \\
\text { previous } 3 \text { months or } \\
\text { alb }<35 \mathrm{~d} / \mathrm{L} \text { ) }\end{array}$ \\
\hline $\begin{array}{l}\text { Smith } 1988 \\
\text { Australia }\end{array}$ & $\begin{array}{l}\text { major upper GI } \\
\text { colorectal } \\
\text { multiple operations }\end{array}$ & $\begin{array}{l}50-60 \mathrm{kcals} / \mathrm{kg} \\
\text { glucose \& amino acid } \\
150 \mathrm{kcals} / 1 \mathrm{~g} \text { nitrogen }\end{array}$ & $\begin{array}{l}10 \text { days } \\
\text { central venous catheter }\end{array}$ & $\begin{array}{l}\text { all (Prognostic nutri- } \\
\text { tional Index }>30 \% \text { ) }\end{array}$ \\
\hline $\begin{array}{l}\text { Von Meyenfeldt } \\
1992 \\
\text { Netherlands }\end{array}$ & $\begin{array}{l}\text { gastric } \\
\text { colorectal }\end{array}$ & $\begin{array}{l}150 \% \\
\text { basal energy expenditure } \\
\text { calculated from Harris \& } \\
\text { Benedict equation }\end{array}$ & $\begin{array}{l}\text { At least } 10 \text { days } \\
\text { enteral - nasogastric } \\
\text { or oral }\end{array}$ & $\begin{array}{l}\text { all depleted (Nutrition } \\
\text { Index) }\end{array}$ \\
\hline
\end{tabular}


Table 1. Characteristics of the trials included on preoperative feeding

\begin{tabular}{|c|c|c|c|c|}
\hline $\begin{array}{l}\text { Braga 2002a } \\
\text { Italy }\end{array}$ & colorectal & $\begin{array}{l}1000 \mathrm{mls} \text { of IE formula } \\
\text { with food ad libitum }\end{array}$ & $\begin{array}{l}5 \text { days } \\
\text { oral }\end{array}$ & $\begin{array}{l}12 \% \text { active } \\
8 \% \text { control } \\
\text { (10\% weight loss in pre- } \\
\text { vious } 6 \text { months) }\end{array}$ \\
\hline $\begin{array}{l}\text { Braga 2002b } \\
\text { Italy }\end{array}$ & $\begin{array}{l}\text { gastric } \\
\text { pancreatic } \\
\text { colorectal } \\
\text { oesophageal }\end{array}$ & $\begin{array}{l}\text { preoperative } 1000 \mathrm{mls} \text { IE } \\
\text { nutrition and standard } \\
\text { enteral postoperatively }\end{array}$ & $\begin{array}{l}7 \text { days } \\
\text { oral preoperatively }\end{array}$ & $\begin{array}{l}\text { weight loss }>10 \% \text { within } \\
\text { the previous } 6 \text { months }\end{array}$ \\
\hline $\begin{array}{l}\text { Gianotti } 2002 \\
\text { Italy }\end{array}$ & $\begin{array}{l}\text { oesophageal } \\
\text { pancreas } \\
\text { colorectal }\end{array}$ & $1000 \mathrm{mls}$ IE formula & $\begin{array}{l}5 \text { days } \\
\text { oral }\end{array}$ & $\begin{array}{l}\text { excluded weight losing } \\
\text { patients }\end{array}$ \\
\hline $\begin{array}{l}\text { Gunerhan } 2009 \\
\text { Turkey }\end{array}$ & GI & not reported & 7 days & $\begin{array}{l}\text { all at risk (subjective } \\
\text { global assessment) }\end{array}$ \\
\hline $\begin{array}{l}\text { McCarther } 1998 \\
\text { America }\end{array}$ & $\begin{array}{l}\text { oesophagus } \\
\text { stomach } \\
\text { pancreas }\end{array}$ & $\begin{array}{l}750 \mathrm{mls} \text { supplement } \\
\text { with added arginine and } \\
\text { omega } 3 \text { fatty acids }\end{array}$ & $\begin{array}{l}7 \text { days } \\
\text { oral }\end{array}$ & $\begin{array}{l}21 \% \text { active } \\
18 \% \text { control }\end{array}$ \\
\hline $\begin{array}{l}\text { Okamoto } 2009 \\
\text { Japan }\end{array}$ & gastric & $750 \mathrm{mls}$ IE formula & $\begin{array}{l}7 \text { days } \\
\text { oral }\end{array}$ & not reported \\
\hline $\begin{array}{l}\text { Xu } 2006 \\
\text { China }\end{array}$ & $\begin{array}{l}\text { gastric } \\
\text { colorectal }\end{array}$ & $\begin{array}{l}25 \mathrm{kcals} / \mathrm{kg} \\
\text { IE nutrition \& oral diet }\end{array}$ & $\begin{array}{l}7 \text { days } \\
\text { nasogastric }\end{array}$ & not reported \\
\hline $\begin{array}{l}\text { Burden } 2011 \\
\text { United Kingdom }\end{array}$ & colorectal & $\begin{array}{l}400 \mathrm{mls} \text { standard supple- } \\
\text { ment between meals } \\
72 \% \text { managed } 400 \mathrm{mls} \\
16 \% \text { managed } 200 \mathrm{mls}\end{array}$ & oral & $\begin{array}{l}46 \% \text { at risk using subjec- } \\
\text { tive global assessment }\end{array}$ \\
\hline $\begin{array}{l}\text { Smedley } 2004 \\
\text { United Kingdom }\end{array}$ & $\begin{array}{l}\text { lower } \\
\text { GI } \\
\text { surgery }\end{array}$ & $\begin{array}{l}\text { ad libitum standard sup- } \\
\text { plement in between } \\
\text { meals }\end{array}$ & oral & $\begin{array}{l}34 \% \text { at risk (determined } \\
\text { by body mass index \& } \\
\text { weight loss) }\end{array}$ \\
\hline $\begin{array}{l}\text { MacFie } 2000 \\
\text { United Kingdom }\end{array}$ & $\begin{array}{l}\text { colorectal } \\
\text { GI } \\
\text { hepatobiliary }\end{array}$ & $\begin{array}{l}\text { minimum of } 2 \text { supple- } \\
\text { ments a day } \& \text { normal } \\
\text { diet }\end{array}$ & oral & $\begin{array}{l}17 \text { patients lost }>10 \% \\
\text { weight in previous } 6 \\
\text { months }\end{array}$ \\
\hline
\end{tabular}


Table 2. Outcomes and postoperative management

\begin{tabular}{|c|c|c|c|c|c|c|c|}
\hline Study & complications & mortality & $\begin{array}{l}\text { Anthropome- } \\
\text { try }\end{array}$ & Biochemisty & $\begin{array}{l}\text { Oral nutri- } \\
\text { tional intake }\end{array}$ & $\begin{array}{l}\text { Postoperative } \\
\text { management }\end{array}$ & length of stay \\
\hline Muller 1982 & $\begin{array}{l}\text { major } \\
\text { infections } \\
\text { standardised } \\
\text { observation } \\
\text { forms used }\end{array}$ & $\begin{array}{l}\text { control-11 } \\
\text { active-3 } \\
\mathrm{P}=<0.05\end{array}$ & weight & $\begin{array}{l}\text { albumin } \\
\text { prealbumin }\end{array}$ & - & $\begin{array}{l}\text { postoperative } \\
\text { infusion } \\
\text { regimen iden- } \\
\text { tical for both } \\
\text { groups }\end{array}$ & not reported \\
\hline Smith 1988 & $\begin{array}{l}\text { major } \\
\text { minor } \\
\text { pre defined } \\
\text { classification }\end{array}$ & $\begin{array}{l}\text { control-3 } \\
\text { active- } 1\end{array}$ & $\begin{array}{l}\text { weight } \\
\text { triceps skin } \\
\text { folds }\end{array}$ & $\begin{array}{l}\text { albumin } \\
\text { transferrin }\end{array}$ & - & $\begin{array}{l}\text { Re- } \\
\text { ceived postop } \\
\text { nutritional } \\
\text { support if sur- } \\
\text { geon deemed } \\
\text { necessary }\end{array}$ & $\begin{array}{l}\text { no significant } \\
\text { difference }\end{array}$ \\
\hline $\begin{array}{l}\text { Von } \\
\text { Meyenfeldt } \\
1992\end{array}$ & $\begin{array}{l}\text { infectious } \\
\text { non- } \\
\text { infectious } \\
\text { defined in } \\
\text { manuscript }\end{array}$ & $\begin{array}{l}\text { PN-2 } \\
\text { EN-4 } \\
\text { control } 2\end{array}$ & not reported & albumin & not reported & $\begin{array}{l}\text { PN continued } \\
\text { until oral in- } \\
\text { take postop } \\
\text { Other groups } \\
\text { increased } \\
\text { amounts of } \\
\text { food and fluid } \\
\text { as tolerated }\end{array}$ & $\begin{array}{l}\text { postop hospi- } \\
\text { tal } \\
\text { stay no } \\
\text { significant dif- } \\
\text { ference. LOS } \\
\text { longer } \\
\text { preop in treat- } \\
\text { ment groups }\end{array}$ \\
\hline Braga 2002a & $\begin{array}{l}\text { infective } \\
\text { total } \\
\text { defined by } \\
\text { Bozzotti } 2001\end{array}$ & $\begin{array}{l}\text { active }-0 \\
\text { control }-1\end{array}$ & not reported & not reported & not reported & $\begin{array}{l}4 \text { different } \\
\text { groups in trial } \\
\text { IN preop only, } \\
\text { IN pe- } \\
\text { riop, standard } \\
\text { nutrition pe- } \\
\text { riop \& control }\end{array}$ & $\begin{array}{l}\text { IN } \\
\text { versa no nu- } \\
\text { trition \& IN } \\
\text { versa standard } \\
\mathrm{P}=<0.0005\end{array}$ \\
\hline Braga 2002b & $\begin{array}{l}\text { major } \\
\text { infections } \\
\text { infectious } \\
\text { non- } \\
\text { infectious } \\
\text { defined in } \\
\text { manuscript }\end{array}$ & $\begin{array}{l}\text { Group 1-2 } \\
\text { Group 2-1 } \\
\text { Group 3-0 }\end{array}$ & $\begin{array}{l}\text { reported at } \\
\text { baseline not as } \\
\text { an outcome }\end{array}$ & $\begin{array}{l}\text { reported at } \\
\text { baseline }\end{array}$ & not reported & $\begin{array}{l}\text { control and } \\
\text { preop group } \\
\text { given same en- } \\
\text { teral formula }\end{array}$ & $\begin{array}{l}\text { preop group } \\
\text { versa control } \\
\text { group } \mathrm{P}=0.01\end{array}$ \\
\hline Gianotti 2002 & $\begin{array}{l}\text { infective } \\
\text { total } \\
\text { defined by } \\
\text { Bozzotti }\end{array}$ & $\begin{array}{l}\text { active }-1 \\
\text { control }-1\end{array}$ & weight & not reported & not reported & $\begin{array}{l}3 \text { different } \\
\text { groups in trial } \\
\text { IN preop only, } \\
\text { IN periop and } \\
\text { control (no } \\
\text { nutrition) }\end{array}$ & $\begin{array}{l}\text { preop IN versa } \\
\text { control } \mathrm{P}=0 \text {. } \\
008\end{array}$ \\
\hline
\end{tabular}

Pre-operative Nutrition Support in Patients Undergoing Gastrointestinal Surgery. (Review) 
Table 2. Outcomes and postoperative management (Continued)

\begin{tabular}{|c|c|c|c|c|c|c|c|}
\hline $\begin{array}{l}\text { Gunerhan } \\
2009\end{array}$ & $\begin{array}{l}\text { infectious } \\
\text { non infectious }\end{array}$ & not reported & $\begin{array}{l}\text { reported at } \\
\text { baseline }\end{array}$ & $\begin{array}{l}\text { CRP } \\
\text { prealbumin } \\
\text { nitrogen bal- } \\
\text { ance }\end{array}$ & not reported & $\begin{array}{l}\text { preop IN } \\
\text { preop std nu- } \\
\text { trition } \\
\text { control - no } \\
\text { nutrition }\end{array}$ & $\begin{array}{l}\text { no significant } \\
\text { difference }\end{array}$ \\
\hline $\begin{array}{l}\text { McCarther } \\
1998\end{array}$ & $\begin{array}{l}\text { infectious } \\
\text { non infectious } \\
\text { complications }\end{array}$ & $\begin{array}{lll}\text { group } & 1 & 0 \\
\text { group } & 2 & 1 \\
\text { group } & 3 & 0\end{array}$ & not reported & not reported & not reported & $\begin{array}{l}1 \text { std supple- } \\
\text { ment } \\
2 \text { std plus argi- } \\
\text { nine } \\
3 \text { arginine plus } \\
\text { omega } 3\end{array}$ & $\begin{array}{l}\text { no significant } \\
\text { difference }\end{array}$ \\
\hline $\begin{array}{l}\text { Okamoto } \\
2009\end{array}$ & $\begin{array}{l}\text { infectious } \\
\text { non infectious } \\
\text { defined in } \\
\text { manuscript }\end{array}$ & not reported & $\begin{array}{l}\text { weight loss } \\
\text { skin fold } \\
\text { thickness } \\
\text { arm } \\
\text { circumference }\end{array}$ & $\begin{array}{l}\text { prealbumin } \\
\text { transferrin }\end{array}$ & not reported & $\begin{array}{l}\text { both groups } \\
\text { received } \\
\text { postop care }\end{array}$ & $\begin{array}{l}\text { no significant } \\
\text { difference }\end{array}$ \\
\hline $\begin{array}{l}\text { Xu } 2006 \\
\text { China }\end{array}$ & $\begin{array}{l}\text { infectious } \\
\text { non infectious }\end{array}$ & not reported & $\begin{array}{l}\text { weight be- } \\
\text { tween groups }\end{array}$ & not reported & not reported & $\begin{array}{l}\text { both } \\
\text { groups fed en- } \\
\text { terally with a } \\
\text { standard for- } \\
\text { mula }\end{array}$ & $\begin{array}{l}\text { significantly } \\
\text { shorter } \\
\mathrm{P}=0.05\end{array}$ \\
\hline Burden 2011 & $\begin{array}{l}\text { infectious } \\
\text { non infectious } \\
\text { Buzby } 1988 \\
\text { CDC } 1993\end{array}$ & $\begin{array}{l}\text { not reported } \\
\text { separately }\end{array}$ & not reported & not reported & $\begin{array}{l}\text { significant dif- } \\
\text { ference in en- } \\
\text { ergy intake be- } \\
\text { tween control } \\
\text { and interven- } \\
\text { tion but not } \\
\text { for protein }\end{array}$ & $\begin{array}{ll}\text { sip feeds given } \\
\text { up } \quad \text { until } \\
\text { surgery }\end{array}$ & $\begin{array}{l}\text { no significant } \\
\text { difference }\end{array}$ \\
\hline Smedley 2004 & $\begin{array}{l}\text { minor } \\
\text { major } \\
\text { Buzby } 1988\end{array}$ & $\begin{array}{l}\text { not reported } \\
\text { separately }\end{array}$ & $\begin{array}{l}\text { no significant } \\
\text { differences be- } \\
\text { tween groups }\end{array}$ & not reported & $\begin{array}{l}\text { sip feeds preop } \\
\text { compared } \\
\text { to control sig- } \\
\text { nificant differ- } \\
\text { ence } \\
2528 \quad \text { kcals/ } \\
606\end{array}$ & $\begin{array}{l}4 \\
\text { groups in trial } \\
\text { sip feeds preop } \\
\text { compared } \\
\text { with control }\end{array}$ & $\begin{array}{l}\text { no significant } \\
\text { difference }\end{array}$ \\
\hline MacFie 2000 & $\begin{array}{l}\text { total compli- } \\
\text { cations } \\
\text { septic compli- } \\
\text { cations }\end{array}$ & $\begin{array}{l}\text { preop sip feeds } \\
1 \\
\text { control } 1\end{array}$ & $\begin{array}{l}\text { body weight } \\
\text { mid arm cir- } \\
\text { cumference } \\
\text { grip strength } \\
\text { no sig- } \\
\text { nificant differ- } \\
\text { ence in groups }\end{array}$ & albumin & $\begin{array}{l}\text { mean } \\
507 \text { kcals in } \\
\text { preop period } \\
\text { from supple- } \\
\text { ments no sig- } \\
\text { nificant differ- } \\
\text { ence in Kcal } \\
\text { intake }\end{array}$ & $\begin{array}{l}4 \text { groups only } \\
\text { compared } \\
\text { data } \\
\text { in preop group } \\
\text { and control }\end{array}$ & $\begin{array}{l}\text { no significant } \\
\text { difference }\end{array}$ \\
\hline
\end{tabular}

Pre-operative Nutrition Support in Patients Undergoing Gastrointestinal Surgery. (Review) 
Table 3. Adverse effects or complications of feed or route of delivery

\begin{tabular}{|c|c|c|c|}
\hline Study & GI & Metabolic & Route \\
\hline Muller 1982 & nil & $\begin{array}{l}7 \text { instances of elevated } \\
\text { liver function tests }\end{array}$ & 4 CVC related \\
\hline Smith 1988 & nil & nil & 2 febrile episodes \\
\hline $\begin{array}{l}\text { Von Meyenfeldt } \\
1992\end{array}$ & $\begin{array}{l}3 \text { in enteral group diarrhoea } \\
3 \text { vomiting } \\
2 \text { gastric retention }\end{array}$ & nil & $\begin{array}{l}1 \text { arterial puncture } \\
1 \text { pneumothorax } \\
4 \text { catheter related sepsis }\end{array}$ \\
\hline Braga 2002a & $\begin{array}{l}18 \text { abdominal cramping or } \\
\text { bloating } \\
9 \text { diarrhoea } \\
3 \text { postoperative vomiting }\end{array}$ & nil & $\begin{array}{l}\text { nasojejunal tube blocked } \\
\text { in } 5 \text { patients }\end{array}$ \\
\hline Braga 2002b & $\begin{array}{l}29 \text { cramping and distention } \\
13 \text { diarrhoea } \\
4 \text { vomiting }\end{array}$ & nil & nil \\
\hline Gianotti 2002 & $\begin{array}{l}\text { cramping and distention } \\
\text { diarrhoea } \\
\text { vomiting }\end{array}$ & not reported & \\
\hline Gunerhan 2009 & not reported & not reported & not reported \\
\hline McCarther 1998 & $\begin{array}{l}\text { cramping } \\
\text { bloating } \\
\text { distention } \\
\text { gas }\end{array}$ & nil & nil \\
\hline Okamoto 2009 & not reported & not reported & not reported \\
\hline $\begin{array}{l}\text { Xu } 2006 \\
\text { China }\end{array}$ & not reported & not reported & not reported \\
\hline Burden 2011 & $\begin{array}{l}4 \text { nausea } \& \text { vomiting } \\
2 \text { diarrhoea }\end{array}$ & nil & not appropriate \\
\hline Smedley 2004 & not reported & nil & not appropriate \\
\hline MacFie 2000 & nil in preop group & nil & not appropriate \\
\hline
\end{tabular}




\section{A P P E N D I C E S}

\section{Appendix I. Search strategy}

1. exp Preoperative Period/ or exp Preoperative Care/ or preoperative.mp.

2. exp Perioperative Nursing/ or exp Perioperative Care/ or perioperative.mp.

3. 1 or 2

4. exp Food, Formulated/ or exp Nutritional Status/ or exp Dietary Supplements/ or exp Malnutrition/ or exp Enteral Nutrition/ or sip feeds.mp. or exp Nutritional Requirements/

5. Oral supplements.mp.

6. parenteral nutrition.mp. or exp Parenteral Nutrition/

7. exp Parenteral Nutrition/ or exp Enteral Nutrition/ or enteral.mp.

8. jejunostomy.mp. or exp Jejunostomy/

9. exp Enteral Nutrition/ or nasogastric.mp.

10. gastrostomy.mp. or exp Gastrostomy/

11.4 or 5 or 6 or 7 or 8 or 9 or 10

12. exp Glutamine/ or exp Food, Formulated/ or exp Arginine/ or exp Fatty Acids,

Omega-3/ or immunonutrition.mp.

13. Novel substrates.mp.

14. exp Carbohydrates/ or carbohydrate.mp.

15. glucose.mp. or exp Glucose/

16. protein.mp. or exp Proteins/

17. Amino acids.mp. or exp Amino Acids/

18. 12 or 13 or 14 or 15 or 16 or 17

19. exp Esophagectomy/ or gastrointestinal surgery.mp. or exp Gastrectomy/

20. colorectal surgery.mp. or Colorectal Surgery/

21. exp Gastrectomy/ or gastric cancer surgery.mp.

22. exp Esophagectomy/ or oesophageal cancer surgery.mp.

23. pancreatic cancer surgery.mp. or exp Digestive System Surgical Procedures/ or exp Pancreatectomy/ or exp Pancreaticoduodenectomy/

24. 19 or 20 or 21 or 22 or 23

25.4 or 5 or 6 or 7 or 8 or 9 or 10 or 12 or 13 or 14 or 15 or 16 or 17

26. 3 and 11 and 18 and 24

\section{H I S T O R Y}

Protocol first published: Issue 12, 2010

Review first published: Issue 11, 2012

\section{CONTRIBUTIONSOFAUTHORS}

SB - Written proposal, CT, JH \& SL commented on proposal, CT - Assisted with search strategy.

Pre-operative Nutrition Support in Patients Undergoing Gastrointestinal Surgery. (Review) 


\section{DECLARATIONSOF INTEREST}

None to declare

\section{SOURCES OF SUPPORT}

\section{Internal sources}

- No sources of support supplied

\section{External sources}

- Macmillan Cancer Support, UK.

Financial Support

\section{DIFFERENCES BETWEEN PROTOCOLAND REVIEW}

The data derived from the included trials did not allow any sensitivity analyses or sub group analyses.

\section{NDEX TERMS}

\section{Medical Subject Headings (MeSH)}

${ }^{*}$ Digestive System Surgical Procedures; Enteral Nutrition [ ${ }^{*}$ methods]; Length of Stay; Malnutrition [ ${ }^{*}$ therapy]; Parenteral Nutrition [*methods]; Postoperative Complications [ ${ }^{*}$ prevention \& control]; Preoperative Care [ ${ }^{*}$ methods]; Randomized Controlled Trials as Topic

\section{MeSH check words}

Humans 